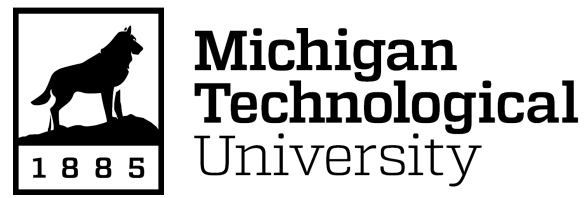

Michigan Technological University Digital Commons @ Michigan Tech

Dissertations, Master's Theses and Master's Reports

2017

\title{
AMENDING THE CORPORATE CRISIS RENEWAL MODEL: LESSONS FROM OIL AND PALM CRISES IN WEST AFRICA
}

Vincent Manzie

Michigan Technological University, vdmanzie@mtu.edu

Copyright 2017 Vincent Manzie

\section{Recommended Citation}

Manzie, Vincent, "AMENDING THE CORPORATE CRISIS RENEWAL MODEL: LESSONS FROM OIL AND PALM CRISES IN WEST AFRICA", Open Access Dissertation, Michigan Technological University, 2017. https://doi.org/10.37099/mtu.dc.etdr/520 
AMENDING THE CORPORATE CRISIS RENEWAL MODEL: LESSONS FROM OIL AND PALM CRISES IN WEST AFRICA

By

Vincent D. Manzie

\begin{abstract}
A DISSERTATION
Submitted in partial fulfillment of the requirements for the degree of DOCTOR OF PHILOSOPHY

In Rhetoric, Theory and Culture
\end{abstract}

MICHIGAN TECHNOLOGICAL UNIVERSITY

2017

C 2017 Vincent D. Manzie 
This dissertation has been approved in partial fulfillment of the requirements for the Degree of DOCTOR OF PHILOSOPHY in Rhetoric, Theory and Culture.

Department of Humanities

\author{
Dissertation Advisor: $\quad$ Patricia Sotirin \\ Committee Member: $\quad$ Beatrice Smith \\ Committee Member: Ramon Fonkoue \\ Committee Member: Kari Henquinet
}

Department Chair: $\quad$ Dr. Ronald Strickland 


\section{Dedication}

To my parents, Goodboy Manzie and Celine Manzie.

My wife, Maikem Emmanuela Manzie 


\section{Table of Contents}

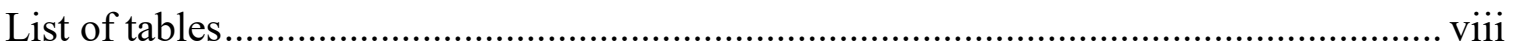

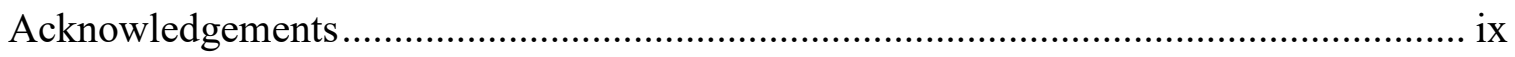

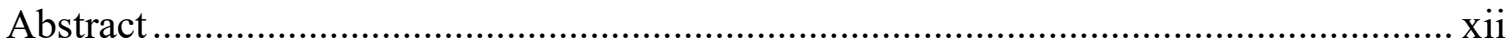

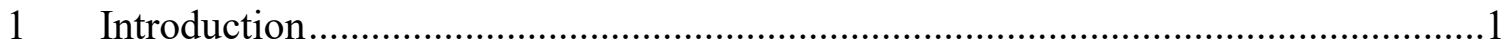

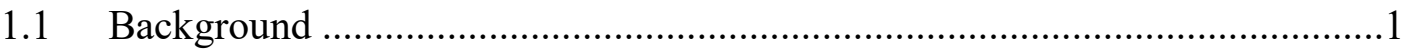

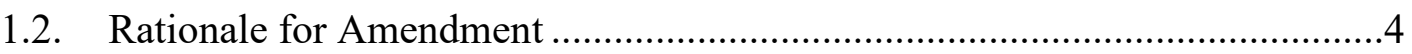

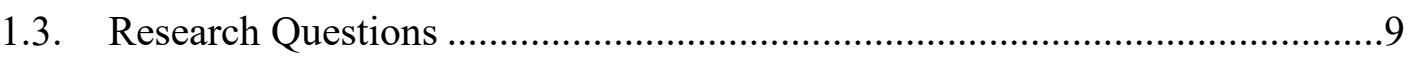

1.4 Brief Overview of Remaining Chapters ……………................................... 10

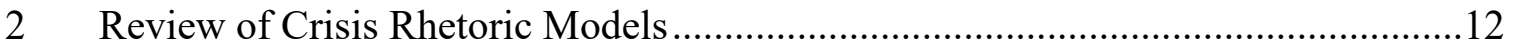

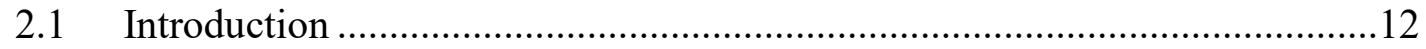

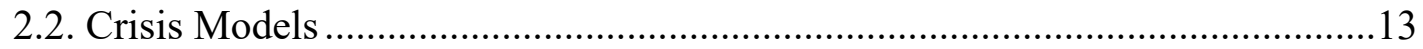

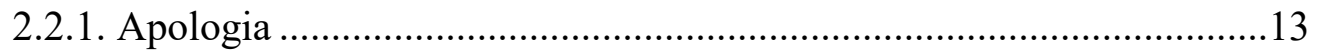

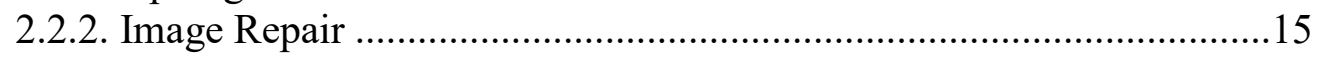

2.2.3. Situational Crisis Communication Theory (SCCT) ..............................16

2.2.4. The Rhetorical Approach ................................................................... 17

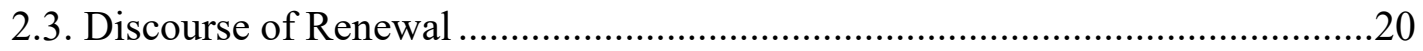

2.4. Theoretical Components of Discourse of Renewal ..........................................22

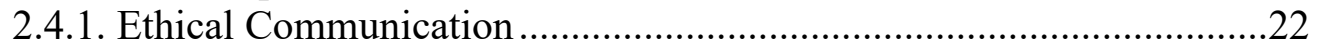

2.4.2. Prospective versus Retrospective vision ...........................................23

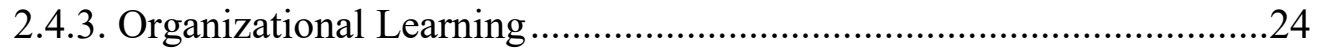

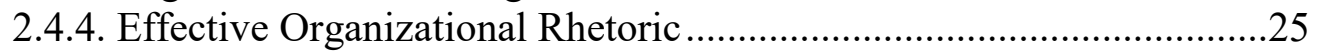

2.5. Implication of renewal components for Crisis Communication........................26

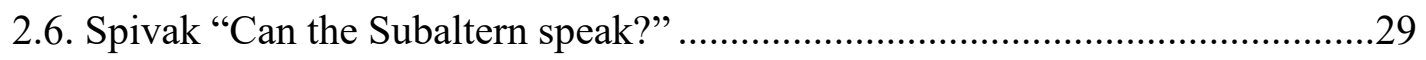

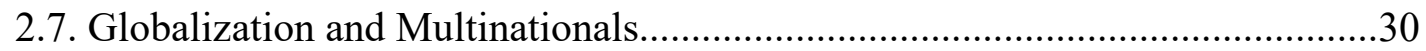

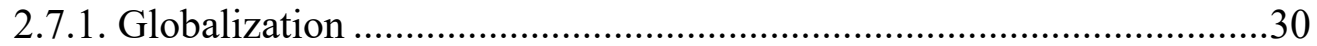

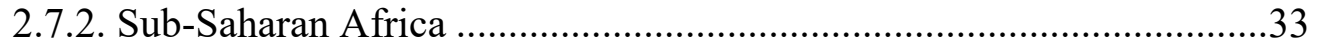

2.7.3. Multinational Corporations (MNCs) .....................................................

2.7.3.1. MNCs' Dominance - Economic and Social.......................................37

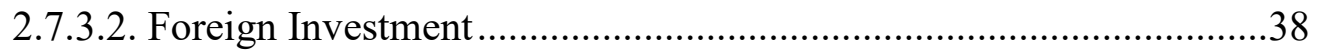

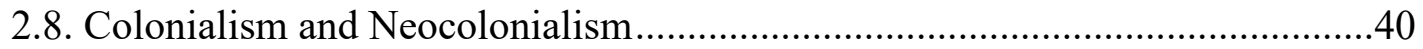

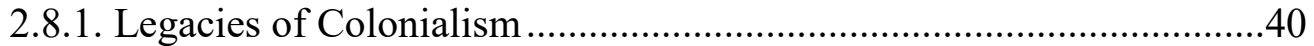

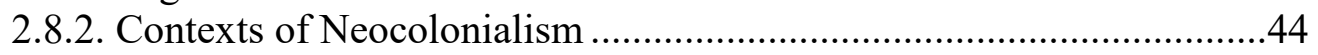




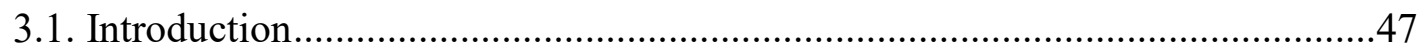

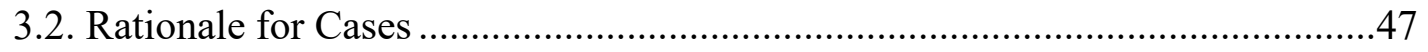

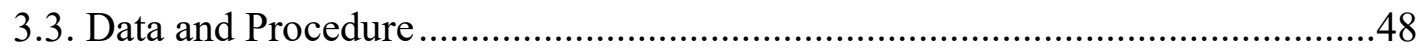

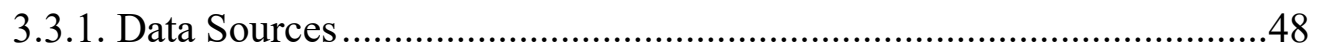

3.3.2. Data Collection Strategies and Organization .......................................50

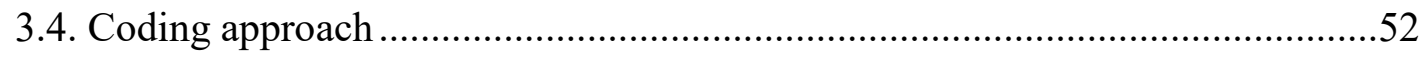

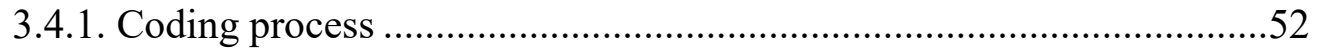

3.4.2. Conceptualizing and Operationalizing Categories ...............................53

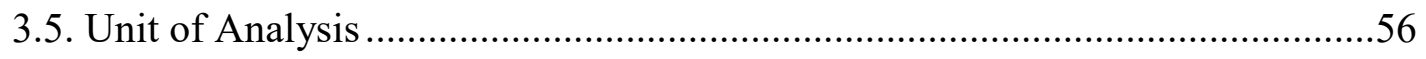

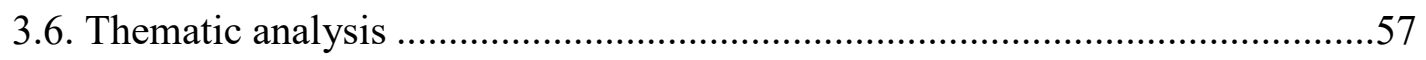

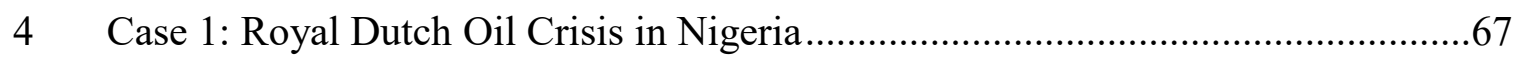

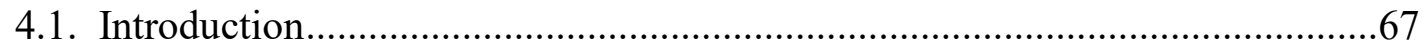

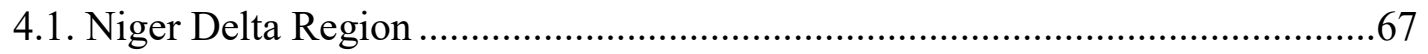

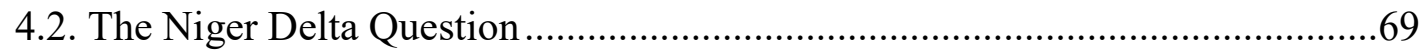

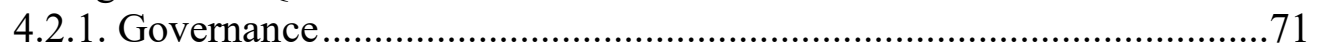

4.2.2. Economic and Social relations .....................................................

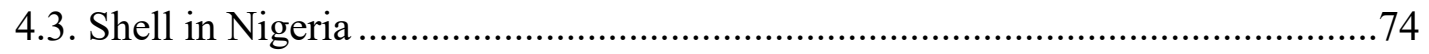

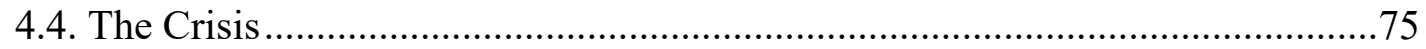

4.4.1. Oil Spills and Gas Flaring ………………….................................... 75

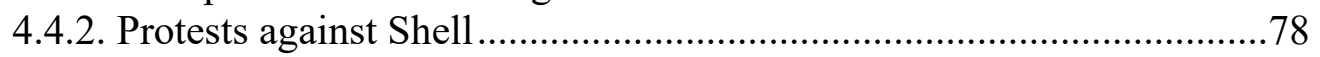

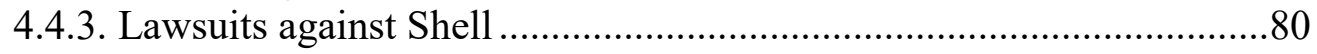

4.5. Shell's crisis communication and management approach ..................................8 81

4.5.1. Old Approach to Crisis (1993-mid-2000s) ...........................................8 82

4.5.2. New Approach to Crisis (2006-2016) ………………...........................8

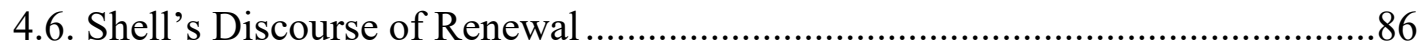

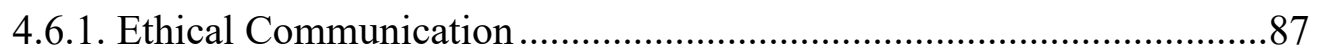

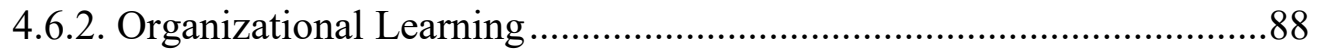

4.6.3. Prospective vs. Retrospective Vision .................................................90

4.6.4. Effective Organizational Rhetoric ………………................................92

4.7. Response to Shell's Discourse of Renewal........................................................94

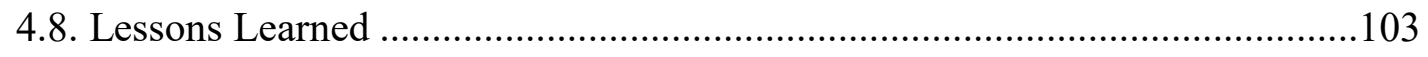

5 Case 2: Herakles Farms Palm Crisis in Cameroon ...................................................106

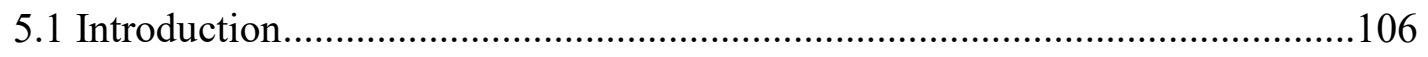

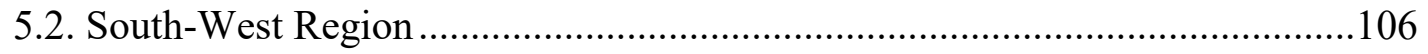


5.2.1 History 107

5.2.2. Political Geography of Plantation Sites. 109

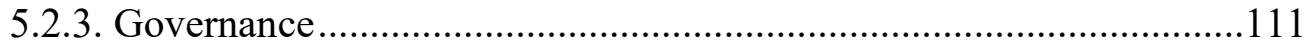

5.2.4. Economic and Social Relations ........................................................112

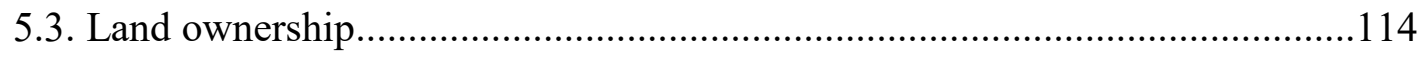

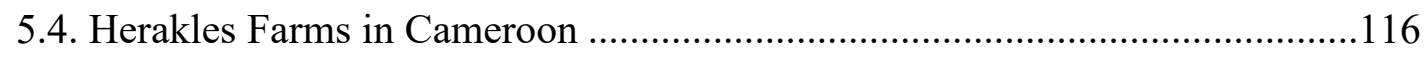

5.4.1. Bruce Wrobel: Benevolent Capitalist? ...............................................117

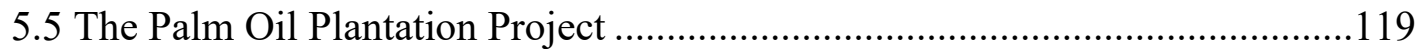

5.5.1. The Plantation Project Sites.............................................................121

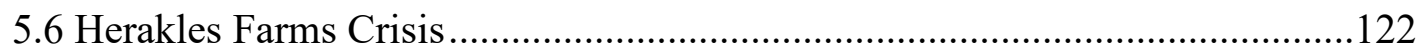

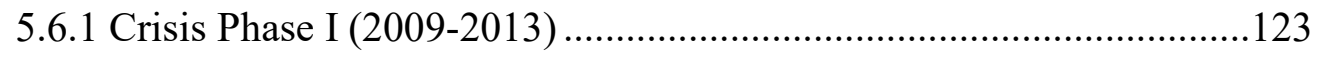

5.6.2 Government Opposition to Herakles Farms …………………............123

5.6.3. Community Opposition to Herakles Farms ...........................................125

5.6.4. Oppositional Struggles by Local and International NGOs.................126

5.6.5. Crisis Phase II (2014-2016)...............................................................129

5.7. Herakles Farms Crisis Management and Communication Approach...............131

5.7.1. Phase I Crisis Communication Response ..........................................131

5.7.2. Phase II Crisis Communication Response............................................137

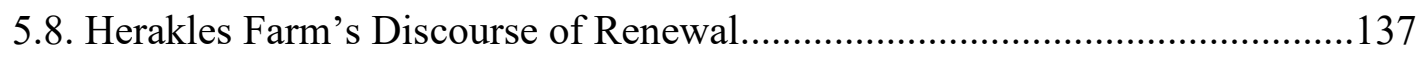

5.8.1. Ethical Communication ....................................................................137

5.8.2 Prospective vs. Retrospective Vision ..................................................139

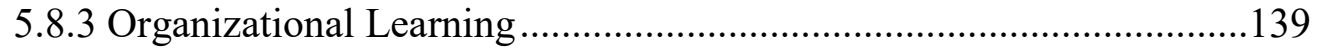

5.8.4 Effective Organizational Rhetoric .......................................................140

5.9. Communities' Response to Herakles Farms' Discourse of Renewal ...............141

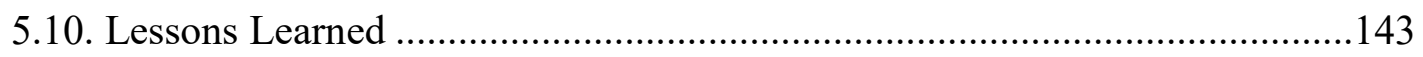

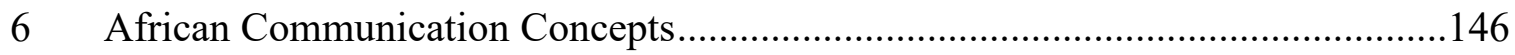

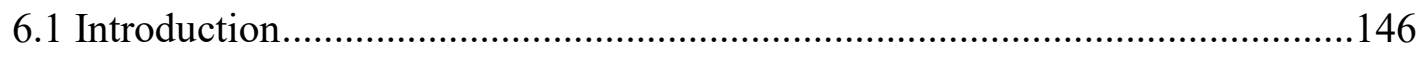

6.2. Review of African Communication Concepts ................................................146

6.3. Key Concepts of African Communication......................................................150

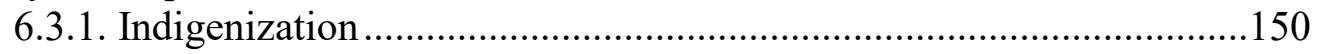

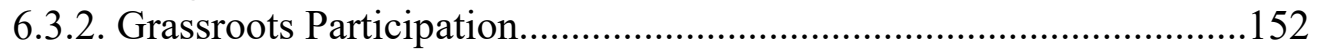

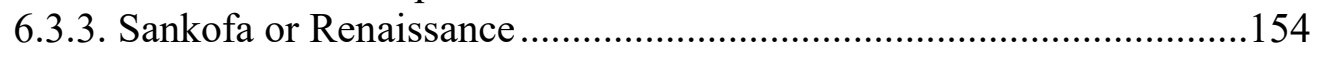

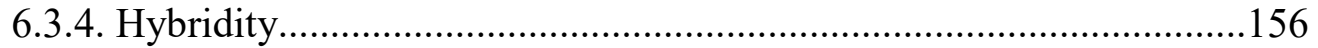

6.3.5. A Shift from Centrifugal to Centripetal Structures ..............................157

6.4. Lessons Learned for Multinational Crisis Communication...............................158

6.1 6.5. MNCs and Capitalistic Corruption ......................................................... 160 


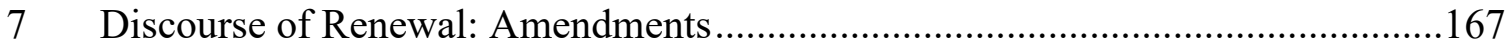

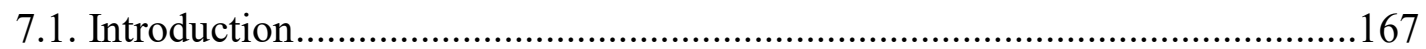

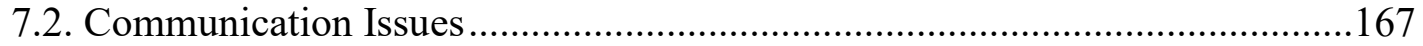

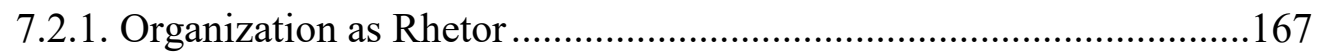

7.2.2. Communication as Transmission ....................................................170

7.2.3. Participatory Communication from Above ....................................170

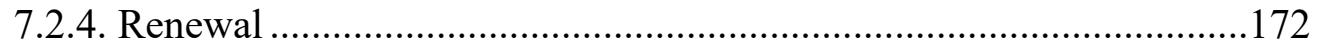

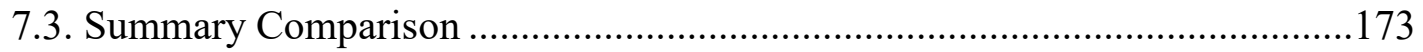

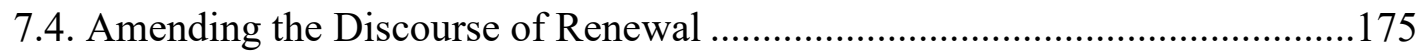

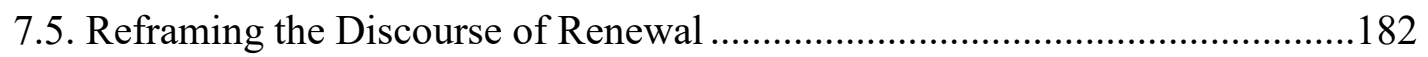

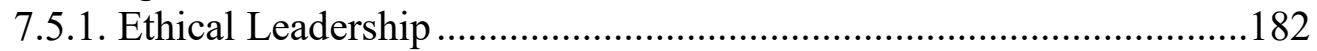

7.5.2. Prospective versus Retrospective Vision...................................... 187

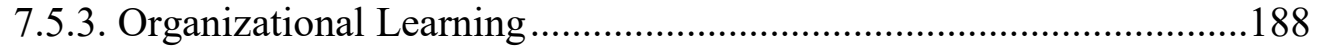

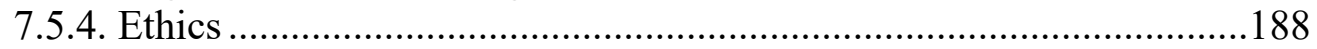

7.6. Implications for Current Crisis Renewal Model..............................................194

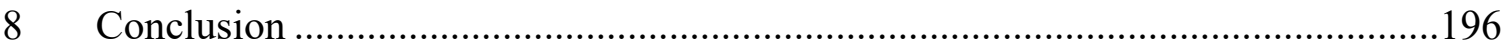

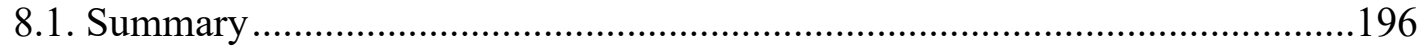

8.1.1. Summarizing Research Questions ................................................196

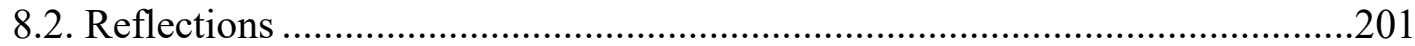

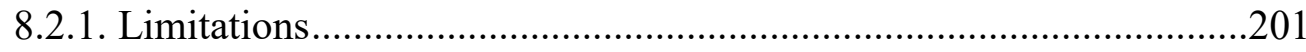

8.2.2 Proactive Renewal Studies as Engaged Scholarship .........................202

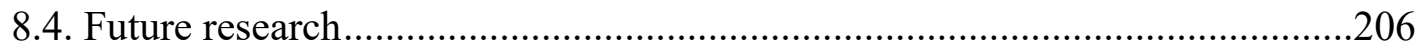

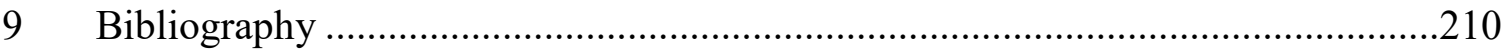




\section{List of tables}

Table 1. Coding Categories of the Discourse of Renewal..........................................54

Table 2. Themes in Communities' Response to Shell's Renewal Discourse.............58

Table 3. Themes in Communities' Response to Herakles Farms' Renewal Discourse.....60

Table 4. Benoit's Image Repairs Typologies Applied to Cases.......................64

Table 5. Amended model: Responsive Hybridity as addition.......................194 


\section{Acknowledgements}

I am forever indebted to my advisor, Dr. Patricia Sotirin, who, for the four and a half years of my graduate studies, has consistently supported me: mentoring me in ways that I became transformed and matured academically, psychologically and emotionally compared to when I first joined my $\mathrm{PhD}$ program. Dr. Sotirin's related with me in ways that were beyond that of a 'professor-student' or 'advisor-mentee' relationship - she is indeed someone I look up to as I pursue my academic and career interests. I also want to acknowledge her professional mentoring which has been so valuable to me. Dr. Sotirin's critical-interpretive approaches to issues of culture, relationality, and communication were indispensable for my dissertation. I was fortunate to benefit from her critical perspectives which draw on discursive theories of communication, critical management studies and qualitative methodologies. I will never miss any opportunity to tap from her academic, professional, and life's advice.

I am also grateful and thankful to my dissertation committee members: Dr.

Beatrice Smith, Dr. Ramon Fonkoue and Dr. Henquinet. Dr. Smith's expertise in globalization studies was of enormous impact for this dissertation. Dr. Smith steered me towards a reading list that solidified the approach I took with regards to the impact of globalization on my work. Dr. Smith's comments and advise for revising my research were enormous, and I really appreciate her time and commitment in my dissertation work. Dr. Fonkue's work on postcolonial theory, cultural contacts, African studies and history was very helpful in my research. I am thankful for the perspectives I tapped from Dr. Fonkoue and his comments and encouragements during my research were boosters. 
Dr. Henquinet was helpful with her experience and training in West Africa studies. I appreciate her comments and advice in my drafts and the additional reading suggestions to better the cases analyzed in the dissertation. Committee members were there from my dissertation proposal until the dissertation was complete.

The department chair, Dr. Ronald Strickland, has been phenomenal in ensuring that I studied in a conducive environment. I am so thankful for the graduate teaching assistantship which the department offered me. I could study effectively and got my teaching skills sharpened through years of teaching as a Graduate Teaching Instructor, thanks to the assistantship. I also sincerely thank Dr. Kitalong whose mentoring in pedagogical processes and practice strengthened and transformed my approach to teaching in an American university classroom.

I acknowledge all other professors in the department whose classes I took. The courses provided the springboard on which my dissertation was built.

At this point I like to acknowledge the fervent support of my wife, Emmanuela Maikem Kimah-Manzie for having to bear with me all these years: the prayers and constant encouragement that came from Emmanuela as I worked on my dissertation helped me in completing my dissertation.

Finally, I will forever remain thankful to my Dad (Goodboy Manzie) and my late mom (Celine Manzie). I learned a lot from the humble and quiet life my dad and mom live/lived. I learned to be resilient in the face of obstacles - including those hard moments which I could not explain their origins. And to this, I am sincerely acknowledging the 
grace of God in my life. God has been magnificent in leading me and preparing my thoughts from the start to the completion of my research. I pray God's face continue shining in my academic and career path. 


\begin{abstract}
This dissertation amends the Crisis Renewal Model of corporate rhetoric based on analyses of two multinational organizational crises in Nigeria and Cameroon. The Renewal model revises the dominant apologia model of corporate crisis rhetoric to focus on strengthening relationships with stakeholders following a crisis rather than solely on repairing or restoring reputation. Yet while the renewal model redresses the classic Aristotelian premises of apologia, the Nigerian and Cameroonian situations call for a significant reframing of rhetorical strategies in response to the colonialist legacies, cultural traditions, political volatilities, and socioeconomic particularities of these contexts. The research questions driving the dissertation are: What are the limitations of the Crisis Renewal model for multinationals operating in West African countries? How can this model be amended based on African communication principles? Data about the cases came from newspapers, company documents, and local and international NGO reports, and radio texts generated from LexisNexis. The data for Shell in Nigeria spans 1993-2016 while the data for Herakles Farms in Cameroon spans 2009-2016. The analyses found that both apologia and renewal were evident in corporate rhetoric produced by Shell and Herakles Farms; nonetheless, their respective crises damaged corporate reputation and stakeholder relationships. Drawing from lessons learned in these cases in West Africa, I turn to African communication concepts of communality and hybridity to rethink the Western premises of the Crisis Renewal model, particularly dimensions of ethical leadership, prospective vision, and organizational learning and build on Spivak's arguments in "Can the Subaltern Speak?" and Kraidy's notion of hybridity. I propose a concept I call responsive hybridity to modify the Crisis Renewal model. Responsive hybridity reframes renewal as a creative self-reflexive process producing hybrid forms, relationships, and practices.
\end{abstract}

Key words: Crisis renewal model, responsive hybridity, self-reflexivity, multinational corporations, crisis context. 


\section{Introduction}

\subsection{Background}

For contemporary organizations, crises can come in many guises: natural disasters, financial meltdowns, political upheavals, social media outbreaks, management mistakes, product failures, or brand hijacking. The list is long and ever-expanding. Whereas the prevailing sense used to be that crises threatening a corporation's brand (Mitroff, 1986), image, or reputation were rare, today these threats are all too common. The field of corporate crisis communication has emerged in the past two decades in response to this changing actuality.

Corporate crisis communication has developed through case descriptions of the communication strategies used by corporate leaders and spokespeople in reaction to image threats. Based on post-hoc rhetorical analyses, crisis scholars have categorized these strategies. The schemas drew on classical Aristotelian conceptions of apologia, a speaker-centered approach that mitigates the threat to corporate image through various strategies of apology or denial. A later schema is informed by psychological theories of attribution to offer schemas based in stakeholder perceptions of responsibility and blame. Yet the emphasis on corporate leaders, defensive strategies, and the goal of protecting or reinstating corporate image remained. More recently, a proactive and positive approach to corporate crisis communication has been advanced that shifts from post-hoc analyses and defensive strategies to ethical communicative relationships: the Crisis Renewal Model. This dissertation focuses on this renewal theory and seeks to amend it to address 
the stakeholder relationships and local-global complexities in crises faced by multinational corporations operating beyond the U.S.

The renewal model shifts the focus from protecting organizational image and reputation against threats to making the most of opportunities for reducing uncertainties and creating mutually beneficial solutions. The model recommends communication practices that, according to Robert Ulmer, a founder of this perspective, "emphasize collaboration with stakeholders, open communication processes, and honesty and timeliness in providing information about the crisis" (p. 529). Collaboration, honesty, and openness are contrasted to "practices of deception, secrecy, and values of upholding the reputation of [an organization] over human life." The focus is on what leaders value precrisis and the key communication values they should develop in order to build their crisis communication skills.

Ulmer holds that an ethic of significant choice frames the ethicality of crisis communication best practices: This is best facilitated by "providing stakeholders with complete known information about the crisis, avoiding incomplete information, avoiding biased information, avoiding statistics that are inadequately defined or incomplete, avoiding vague or ambiguous communication designed to create erroneous meaning, or using emotional language designed to distort meaning" (p. 532). Whereas reactive crisis responses tend to be utilitarian (doing what is best for the greatest number while ignoring the damage done to the rest), proactive and ethically responsive approaches adopt strategies based in principles of stakeholder equity and corporate transparency, thereby seeking more expansive and lasting solutions to crisis situations. 
This dissertation addresses Ulmer's call for thought leadership in crisis communication not only by contributing to a normative model based on principles of ethical communication but also by redressing the parochial limits of crisis communication scholarship. Crisis communication scholarship has been developed almost exclusively in the U.S. through studies of U.S. corporate crises. Further, the most well-established models are based in classical rhetorical traditions, particularly Aristotelian traditions, that have been canonized in the history of Western rhetoric and particularly in the development of American pedagogies of speaking and writing. For example, one of the premier survey textbooks in the field, The Rhetoric of Western Thought, in continuous production since 1976, extols the Aristotelian and Greco-Roman foundations of philosophical, literary, and oratorical practices and philosophies (Golden, Berquist, \& Coleman, 1976). These models prioritize the corporate rhetor and corporate image, promoting strategies intended to deflect or deny criticism and blame in order to minimize threats.

In contrast, the goal of this dissertation is to consider corporate crisis communication in the context of globalization, specifically, the operations of multinational corporations on the African continent. Prevailing neoliberal management and financial logics exacerbate the impact of crisis reactions for stakeholder relationships. Indeed, the emphasis on short-term profits, efficiency measures, and cost reductions in the tightly-coupled and globalized relations of production, distribution, and consumption especially in such critical and multinational-dominated industries as resource extraction and agribusiness invite proliferating crises and tremendous crisis scalability. In addition, 
the model of communication on which crisis communication models have been founded is itself suspect in the context of African cultures and communicative practices.

Developing collaborative sense-making with local stakeholders most subject to the fallout of corporate crisis management requires attunement to sense-making logics-in-use rather than the imposition of a transcultural model of rhetoric.

\subsection{Rationale for Amendment}

I should immediately point out here that "amendment" in this dissertation means the research is adding to the model so that organizational leaders and spokespersons are able to apply the components that constitute the model in a more responsive manner. But why amend the crisis renewal model through its encounter with multinational crises in sub-Saharan Africa? First, while the presence of multinational enterprises on the African continent is long-standing, financial incentives to exploit resources, labor, and land on the continent have intensified even as conditions of crisis increase--political instabilities, climate disasters, human disasters of famine and disease, the prevalence of violence by both state and disenfranchised actors, widespread civil and state corruption. Clearly, crisis response is requisite to doing business in this region. Second, the contemporary African conjuncture is complex, bringing together a plethora of antagonisms within configurations of neoliberal financialization and post-colonial governance and cultures.

The politics of representation are at the heart of relations of global capital, state stability, sustainable production, and political subjectivities. Thus, amending the renewal model entails confronting relations of power that complicate the model's goals of equity, 
transparency, and ethicality. Note here Bhabba's notion of mimicry: rather than respecting the differences and otherness of local cultures, the renewal model implies the idea of "colonial mimicry" or "the desire for a reformed, recognizable Other, as a subject of a difference that is almost the same but not quite" (Bhabba, 1994, p. 86). Given that there is always ambivalence and slippage between the dominant and the mimic, the renewal model is doomed to inadequacy.

Finally, and critically, the crisis renewal model fails to address its inherent assumptions about power relations. Most troublingly, the model assumes its own universality: values of corporate/paternalistic leadership, ethicality, a certain kind of organizational learning/sense-making, and effective (reality-constructing) rhetoric are assumed to apply everywhere to everyone with no translation needed. Instead of being transcultural, these dimensions are meaningful in situ and as enacted. Hence, they do not offer a one-size-fits-all guarantee of renewal. In addition, a corporate bias unreflectively advances corporate dominance, paternalism, and monologic rhetoric. Despite the ethical injunction to respect stakeholder perspectives and seek equitable participation, the model emphasizes the dominance of corporate leaders over collaborative goals and processes. Hence, a conception of inequitable power relations is inherent to this model. Critical perspectives on organizational communication counter corporate bias and promote systemic change in organization-societal relations (Mumby \& Stohl). Such critical perspectives often champion the enactment of democratic or dialogic relations through resistance to the dominance of corporate interests. However, the African context complicates such goals. For example, the colonialist legacies that permeate histories and 
practices in many African societies lend themselves to a superior/inferior epistemological dynamic that can be readily taken up in crisis responses to dismiss indigenous meanings, perspectives, and moral relations.

In considering the role of multinational corporations in Africa, a critical perspective on crisis rhetoric and renewal must engage two interpenetrating contexts: colonialism and neoliberalism. Colonialism is an economic, political, material, and historical model of power, the legacies of which continue to impact the development of African societies. In the wake of colonialism, Spivak posed a critical discursive question: "Can the subaltern speak?" It is a question that the renewal model of corporate crisis management must address because it is central to the goals of stakeholder equity and ethicality. Yet given the failure to directly question the assumptions about power in this model, renewal remains in thrall to corporatist interests and economic-political exploitations. In her essay, Spivak cautions against taking up conceptions of power developed by Western intellectuals - specifically, Foucault and Deleuze - because such conceptions abet colonialist economic exploitation by marginalizing, erasing, or silencing subaltern others, that is, those who are most marginalized and subjugated in relation to both colonizers and indigenous elites. She points out that her question entails a complicated politics of recognition and representation involving both political proxy (the representation of interests) and re-presentation (existential and ontological presence). Importantly, Spivak's analysis rests on the complications of otherness that are requisite to political and existential self-representation. She shows how otherness can enact a hierarchy of subjugations and silences. Yet, as Hall presciently pointed out, "Our lives 
have been transformed by the struggle of the margins to come into representation-not just to be placed by a dominant, imperializing regime but to reclaim some form of representation for themselves" (p.183).

In the crises considered in the two dissertation case studies, villagers who live the consequences of crisis management by multinational agribusiness or extraction corporations are spoken for in complex articulations issued by chiefs, NGOs, local and national politicians, courts and legal relations, multinational agreements and statements, and local and transnational journalists. Yet these are representations of otherness that depend on the continued marginalization of the villagers themselves. For example, villagers affected by the development of multinational palm oil plantations in Cameroon are disempowered in the very representations advanced in their interests: by local chiefs bribed to consent to negotiations over labor and land; by environmentalist and conservationist NGOs both local and transnational concerned about deforestation, logging, and bushmeat consumption; by a complicated tangle of land-ownership regulations, fees, boards, and courts; by non-profit multinational philanthropic associations like All for Africa seeking to lift them from poverty; by logging and plantation managers making promises about work and pay; by government ministers negotiating "sweetheart deals" with palm oil multinational CEOs and nationalized palm oil companies; by President Biya's vision "Cameroon 2035" in which agricultural "smallholders" figure prominently with little regard for the lived conditions.

In similar ways, African communities continue to be articulated by neoliberalism. Tangled in the politics of representation, neoliberalism frames the global environment as 
a "free market" that encourages competition, efficiency, and economic growth. International financial institutions including the World Bank and the International Monetary Fund (IMF) and other transnational organizations push the logic of expanding free markets; and speak for African states concerning what social, economic and even political realities need to be pursued to ensure growth. Neoliberal policies are touted as the remedy that will save Africans from poverty, ensure economic growth, and reduce dependency on foreign aid. The African states/government on the other hand translate and articulate these neoliberal discourses to local communities. Cameroon's Vison 2035 is a succinct example of how the country's government is articulating the neoliberal agenda for ordinary Cameroonians neglecting the lived experiences of ordinary citizens. Vision 2035 has articulated the 'prosperity' of the country in similar ways that neoliberalism framed its "free market" agenda. Cameroon's vision 2035 has as overarching objective: (1) tying the country's economy to the industrialized West such that; (2) the country's economy is mainstreamed into the "global economy" by opening up local financial markets to foreign trade so that the country attains an "emerging economy" status in the world (see "Platform2035"). Looking at this vision from a more critical perspective, the vision clearly regurgitates neoliberal ideals - by being active in international trade and selling farm products and minerals, Cameroon will be able to acquire enough revenue to develop its own economies and increase production of goods for both national and international consumption. It is thus evident how Vision 2035 frames the Cameroonian experience from the lenses of neoliberal ideologies that continue to foster the paternalistic relationship in which local people must look up to the government and allied Western financial and economic institutions to survive. The 
government discourse of making Cameroon become a "newly industrialized country" (a period when the country moves from primary agricultural production to a manufacturing industry) neglects the lived experiences of local people who must first struggle with multinational corporations over such issues as land ownership, subsistence wages, and civil protection.

Neoliberal policies continue to contribute to the expanding crises plaguing the African continent in the MNCs' scramble for African markets and resources. Even when local NGOs oppose foreign interference in the economic and social life of local communities, the villagers who are most affected by these widening neoliberal policies do not get to speak for themselves. In this situation, we notice international organizations, home government, foreign activists, as well as local NGOs speaking for and about the ordinary people.

\subsection{Research Questions}

Amending the renewal model proceeds in two parts. First, two cases of corporate crisis communication in sub-Saharan African countries will be analyzed. The research questions motivating these case analyses are the following:

RQ1: What are the limitations of the Crisis Renewal model for multinationals operating in West African countries? 
The second part of the amendment project addresses African communication philosophy and how it is a resource for amending the dimensions of the renewal model. Along with explicating this communication philosophy the research question focuses on the salience of this African perspective for the renewal model:

RQ2: How can the Crisis Renewal model be amended based on African communication principles?

\subsection{Brief Overview of Remaining Chapters}

Chapters 2 and 3 establish the analytic framework. Chapter 2 explicates the models of corporate crisis communication and the dimensions of the renewal model. It also frames the larger contexts for the operation of multinational corporations on the African continent including dynamics of globalization, neoliberalism and colonialism. Chapter 3 details the data, coding, and thematic analysis that informs each case. The chapter clearly identifies and describes the analytic frameworks and coding categories and procedures.

Chapters 4 and 5 narrate the cases of Shell Oil in Nigeria and Herakles Farms in Cameroon, respectively. Chapters 4 and 5 also present lessons learned from the cases analyzed; as well as a discussion of what these lessons mean for amending the Renewal Model. Each of these two chapters describes the history of the case and examines evidence of crisis communication strategies by the MNC. In both cases, the MNC shifted strategies, from a defensive apologia to a strategy incorporating dimensions of the renewal model. This is not to claim that either MNC knowingly adopted the renewal 
model; nonetheless, there is convincing evidence that both adopted more stakeholderresponsive strategies at particular moments in their prolonged crises.

Chapter 6 turns to the question of African communication principles and practices as resources for amending the Renewal Model. Chapter 7 draws together both the lessons from chapters 4 and 5 and the African communication principles to propose an amendment to the crisis Renewal Model. Chapter 8 summarizes the findings on the research questions, discusses limitations, future research and draws conclusions. 


\section{Review of Crisis Rhetoric Models}

\subsection{Introduction}

This chapter discusses models of corporate crisis rhetoric that are current in the crisis communication literature. In discussing these models, I lay emphasis on the Discourse of Renewal (also referred to as Organizational Renewal theory and Crisis Renewal Model) for an obvious reason: my research has as its main objective to amend this model. The literature on globalization, and multinational corporations (MNCs) in this chapter further provide relevant complex contexts within which analyses of the MNCs' crisis communication occurs in sub-Saharan Africa.

With the widening interconnectedness in social, cultural, economic, and political relations that the world is experiencing, the local and the global are only separated by blurred lines (Appadurai, 2010; Tomlinson, 2007; Braman, 1996); yet this means that local patterns in social and cultural relations have not been completely erased and cannot be coopted into a model of rhetoric that fails to respond to otherness. Accordingly, this chapter's goal is to examine the theoretical dimensions of the Discourse of Renewal, discuss the foundational conceptual critique framing the amendment that I offer in Chapter 7, and situate the crisis renewal model within the complex contexts of postcolonialism and corporate globalization in order to justify an amendment to the model. 
I begin with a review of crisis communication models, arguing that most models rely too heavily on a neo-Aristotelian framework with a heavy focus on issues of blame and reputation. The Discourse of Renewal, in contrast, draws on contemporary conceptions of corporate rhetoric and ethics. However, this model has not as yet been adequately reframed by relations of globalization, neoliberalism and postcolonialism. I draw attention to the complexities of global politics and multinational corruption as I consider these larger frameworks and their implications for the Discourse of Renewal.

\subsection{Crisis Models}

Crisis communication has been theorized through five major approaches - (1) Corporate Apologia (Hearit, 2006a); (2) Image Repair (Benoit, 1997); (3) Situational Crisis Communication Theory (Coombs, 2007a; Coombs, 1995); Discourse of Renewal (Ulmer, Sellnow, \& Seeger, 2011, 2013); and (5) Rhetorical Approach (Heath \& Millars, 2004). These approaches have guided case studies on organizational crisis (e.g., Hearit, 2006e; Blaney, 2002; Harlow, et al, 2011; Sisco \& Zoch, 2010; Seeger, Ulmer, \& Sellnow, 2005). I begin with apologia given that this has been the foundational model in the area of corporate crisis communication.

\subsubsection{Apologia}

Ware and Linkugel (1973) first established Apologia in the communication discipline as a framework for analyzing public discourses. Apologia according to Ware and Linkugel, is primarily a response of "self-defense" (p. 274). They stated that when speakers engage in self-defense (of their reputation) one of four strategies are applied: 
absolution, vindication, explanation, or justification (p. 282). In these instances speakers seek acquittal or absolution from guilt; the "preservation of the accused's reputation and the recognition of his (sic) greater worth as a human being relative to the worth of his accusers" and "approval" (p. 283). Communication scholars have built on these typologies by Ware and Linkugel to develop extended versions of apologia. Hearit (2006a) referred to Ware and Linkugel (1973) when he explained apologia as originating from classical Greek rhetoric meaning "defense" or "speech in defense" (Hearit, 2006a, p. 4).

While early use of apologia was "concerned with individuals accused of wrong doing who seek to clear their names" (Hearit, 2006a, p. 3), contemporary crisis communication scholars have extended the apologia framework to organizations by investigating how companies or institutions respond to accusations of wrongdoing. Hearit (2006) is one of the scholars who has produced extensive work on corporate apologia to analyze how organizations manage crises (see Hearit, 2006b, 2006c, 2006d, 2006e, \& 2006f) and I will rely on his publications to explain corporate apologia. Image Repair theory (Benoit, 1997), and Situational Crisis Communication Theory (2007) are extensions of the work of Ware and Linkugel (1973) and will be discussed separately because of the widely applied nature of their models in crisis cases.

The main premise of corporate apologia is that organizations will take a defensive position to counter accusations of wrongdoing in order to allay guilt. Several strategic rhetorical responses are advanced: denial, e.g. it did not happen, we are not guilty; counterattack, e.g. "directly attacking the accuser and claiming that the charges are false 
or come from malicious intent" (Hearit, 2006f, p. 124); differentiation, e.g., redefining the context of the misdeed, explaining the wrongdoing, or justifying the event or occurrence; apology, e.g., admitting guilt, and confessing involvement; and legal strategy, e.g., the organization says nothing at all in public, but instead engages in legal actions to "seek legal absolution of their guilt and ignore public concerns" (Hearit, 2006a, p. 125). Overall, the focus of corporate apologia is the denial of wrongdoing by not admitting guilt.

\subsubsection{Image Repair}

Developed by Benoit (1995/1997), Image Repair is an extension of Ware and Linkugel's (1973) apologia discourse. Benoit claims to have “developed a more complete" approach to apologia (p. 265). The main premises of Benoit's theorization are (1) an organization is accused and held responsible for an action or event; and (2) that act or event is considered offensive (Benoit, 1997, p. 178). It is important to note that "unless that company is believed to be responsible for the act" and because "perceptions are more important than reality" (emphasis is original), it is not about whether the company actually committed the act or not. It suffices for the organization's "salient audience" (Benoit, 1997, p. 178) to feel that the act is offensive and believe the organization is responsible for the act. Both conditions must be "thought to be true" by the company's salient audiences for the organization's reputation "to be at risk" (Benoit, 2004, p. 264). The image repair strategies modify the apologia strategies. These strategies include denial (simple denial, and shifting blame); evasion of responsibility (e.g., we were provoked, defeasibility, i.e. lack of information, accident, etc.); offensiveness reduction (e.g. 
bolstering, minimization, differentiation); corrective action (e.g., promises to correct problem); and mortification (e.g., confessing and ask for forgiveness) (Benoit, 1997, pp. 265-269).

Image repair, just as apologia, focuses on how individuals and organizations can choose to correct negative public perceptions directed on them following a crisis. The focus is more on strategic responses or tactics aimed at "clearing" the names of individuals and organizations. Image repair and apologia are crucially denial and blame discourses. Image repair continues to be a dominant model informing crisis communication research that focuses on image management during crisis (Harlow, Brantley, \& Harlow, 2011).

\subsubsection{Situational Crisis Communication Theory (SCCT)}

Coombs (2007) has popularized this approach in crisis communication. While traces of apologia could be seen in this model, the SCCT draws from the attribution theory framework which holds that people make judgements and/or search for the causes of events and "attribute responsibility for an event and will experience emotional reaction to that event" (Coombs, 2007, p. 165). It emphasizes the need for organizational crisis communicators and/or managers to have robust knowledge on the "crisis situation" (i.e.,

type of crisis and performance history), in order to determine which crisis response "will maximize reputational protection" (Coombs, 2007, p. 166). Understanding the type of crisis and the organization's performance history is vital if the crisis manager is to effectively match response strategies to crisis situations. The crisis type is an important component because stakeholders will be more likely to attribute crisis responsibility to 
the organization in some situations than in others. For instance, having categorized crises into clusters (victim, accidental, and preventable), Coombs explains that crises in the victim cluster, for example, will attract sympathy, hence low crisis responsibility attribution on the organization, while preventable cluster crises will attract anger, and so, high crisis responsibility on the organization. Understanding this allows the crisis manager to better match responses to specific crisis events.

Meanwhile, organizations can choose to use either primary or secondary responses or a mix of both. Primary response strategies include denial strategies (e.g. attack, shifting blame, clarification), diminish responses (e.g. excuse, justification), and

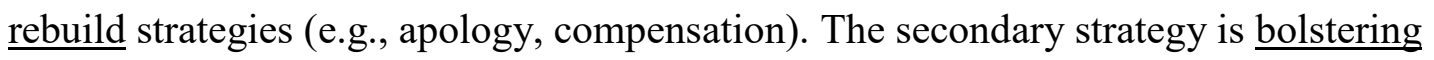
(e.g., ingratiation, victimage, and reminder) (see Coombs \& Holladay, 2004; Coombs, 2007). Using bolstering as a secondary response strategy requires that organizations do one or all of the following during crises: praise stakeholders so stakeholders remain attracted to the organization (ingratiation); play the victim card by telling stakeholders that the organization is also a victim to the crisis (victimage); tell stakeholders of all previous good works of the organization (remind). SCCT as an approach to crisis communication also falls into the category of image management discourses.

\subsubsection{The Rhetorical Approach}

This approach perceives crisis as inherently "rhetorical," that is, as a "rhetorical problem" (Heath \& Millar, 2004, p. 5). The rhetorical problem frames organizational crisis situations as exigencies and argues for the importance of precrisis image management (Crable \& Vibbert, 1983). Heath and Millar (2004) hold that a rhetorical 
problem occurs when situations "call for a statement from one or more persons or organizations" (p. 6). Depending on their locations and "role" in the crisis, organizations, "are looked to for a statement that is a wise, ethical, and strategic response to a rhetorical problem" (Heath \& Millar, 2004, p. 6). This approach holds that there is an "actual dimension" and "perceived dimension" to crises in organization. These dimensions are important because some crises are perceived to be more severe or threatening than they might actually be. And of course, many factors could be behind these perceptions including sabotage.

The rhetorical approach "explicitly acknowledges that the responsibility for the crisis, its magnitude, and its duration are contestable [and] stresses the message development and presentation part of the response" (Heath \& Millar, p. 5). It is about meaning creation and meaning (re)construction, and the need for crisis managers to reflect on the role interpretation plays in crisis responses (Theus, 2004). This perspective points to "what needs to be said before, during, and after a crisis" (Heath \& Millar, 2004, p. 6) and seeks to answer the question, "What can be and must be said to react in a reasonable, responsible, and ethical way to the concerns of the stakeholders affected by the crisis?" (Heath \& Millar, 2004, p. 7).

Using a rhetorical approach, Huxman (2004) classifies crisis communication response strategies following three Aristotelian genres of rhetoric - epideictic, deliberative, and forensic (pp. 292-293). Huxman categorizes the denial strategies as forensic; apology/mortification responses (admitting guilt, and asking for forgiveness), and bolstering as epideictic; and transcendence, corrective action, minimization, as 
deliberative (pp. 292-293). Conceiving a crisis as a "rhetorical problem" has strong implications for communicative responses during crises. A crisis might never be a crisis until so conceived by the organization. In turn, responses are crafted to address how an organization perceives the crisis. Crisis can indeed be manipulated using premeditated communication aimed at denying the existence of a crisis and reconstructing meanings that emerge from the situation.

These four models - (Corporate) apologia, image repair, SCCT, and the rhetorical approach — are tied to the neo-Aristotelian tradition and place considerable emphasis on the corporate rhetor who appears to have insurmountable power in determining the topoi, content, and structure of all communication for dissemination to an audience at the opportune moment. Communication becomes reactive (strategic or tactical) directed by the intentions of the rhetor. It is a defensive approach to communication that we find in these models with an overarching focus being image management and absolution from guilt. But crises are themselves complexities which a defensive, linear, speaker-centered discourse is hardly sufficient to adequately address. Responses to multinational corporate crises cannot be preoccupied with concerns of image or reputation management. Crises reveal centers of power and complex interests in today's global environment. There is therefore a need to address these complexities by moving beyond issues of image and a reactive, defensive rhetorical approach. 


\subsection{Discourse of Renewal}

Introduced by Ulmer, Seeger, and Sellnow in 2007, the Discourse of Renewal (also called organizational renewal theory) shifts from reactive image repair and reputation management accounts to a proactive relational perspective (Seeger \& Ulmer, 2001, 2002; Ulmer, Novak, \& Sellnow, 2005; Ulmer, Seeger, \& Sellnow, 2007). Early formulations of the Discourse of Renewal (Seeger and Ulmer, 2001, 2002) raised concerns about the absence of a critical perspective in crisis rhetoric. Ulmer et al., (2017) argued for ethical, optimistic, provisional, and prospective communication. This perspective is evidenced in the cases of "virtuous responses" by CEO Aaron Feuerstein of Malden Mills, and Milt Cole, owner of Cole Hardwoods during the fire disasters that razed their firms. Seeger, Ulmer, Novak, and Sellnow (2005) further invoked the notion of "change" that accompanies crises, grounding their argument in a study of a "post-crisis discourse of renewal" in the response of executives in the firm Cantor Fitzgerald to the September 11, 2001 World Trade center attacks in which the firm is reported to have lost 658 of its 960 employees.

In the model's early development, the proponents pointed to the following as important characteristics in the Discourse of Renewal: (1) provisional as opposed to strategic responses; (2) prospective rather than retrospective vision; (3) capitalizing on the opportunities embedded in the crisis; and (4) effective leadership (Ulmer et al., 2007). Further, certain conditions were considered to be more conducive for renewal discourse.

First, crisis type: the scholars argued that natural disasters such as floods and fires were more conducive for the application of the discourse of renewal. Second, private 
corporations as opposed to public corporations: private corporations are more conducive for engaging with the discourse of renewal because "there is often more of an entrepreneurial spirit and greater autonomy exercised by private owners of companies" (Ulmer et al., 2007). Also, Ulmer et al., suggested that because owners of private companies are "willing to spend resources" on "rebuilding and moving beyond" crises (p. 133), the discourse of renewal is better conditioned to succeed within privately held companies. Third, corrective action and change: renewal is based on an organization's willingness to correct mistakes and move on. Finally, fourth, stakeholder relationships: sustaining good relationships with stakeholders prior to crisis occurrence is necessary for renewal (Ulmer et al., 2007, p. 130).

Subsequently, Ulmer et al. (2011) developed theoretical dimensions of the discourse of renewal to include: (1) organizational learning; (2) ethical communication; (3) prospective rather than retrospective vision; and (4) effective organizational rhetoric. The ethical communication component includes the need to maintain positive stakeholder relationships prior to crisis and an instinctive or provisional response to crisis. A prospective rather than retrospective vision includes optimism and emphasizes the need to focus on future opportunities. The last component, effective organizational rhetoric, has to do with organizational leaders constructing or "structuring a particular reality for organizational stakeholders and publics" (Ulmer et al., 2011, p. 219). The goal is to make use of opportunities for renewal inherent in crises. The following section elaborates the four theoretical dimensions that inform the discourse of renewal model. 


\subsection{Theoretical Components of Discourse of Renewal}

\subsubsection{Ethical Communication}

This component focuses on a leader-centric, positive, and ethical approach to communication during a crisis, as opposed to a strategic, defensive position. Discourse of Renewal typically "is an immediate and instinctive response based upon the positive values and virtues of a leader rather than a strategic response that emphasizes issues of responsibility or blame” (Ulmer et al., 2011, p. 216; see Sellnow \& Seeger, 2013). In fact, Ulmer, Sellnow, and Seeger (2011) asserted that: “renewal is often based on a leader's established ethical character" (p. 216; also see Sellnow \& Seeger, 2013); ethical communication response to crisis must be "based upon the positive values and virtues of a leader" (p. 216). They maintain that: "Organizations that institute strong, positive value positions with key stakeholders, such as honesty, responsibility, accountability, and trustworthiness, before a crisis happens are best able to create renewal following the crisis" (Ulmer, Sellnow, and Seeger, 2011, p. 215).

Stakeholder relationships are key: to be successful in ethical communication, organizations are called upon to sustain "strong stakeholder relationships," be "provisional rather than strategic" when responding to crisis situations, as well as keeping the standards for "significant choice" (p. 215). Ulmer, et al. suggest organizations "must invest in true equal partnerships" with stakeholders before crisis hits, if the organization is to benefit from stakeholders" "goodwill” during crisis moments (p. 216). Provisional response is spontaneous and/or "instinctive" rather than strategic such as "employing spin to deflect blame from the organization" (p. 216). Talking about "significant choice" as 
an ethical aspect, Ulmer et al. insist on the need for organizational leadership to communicate about "what is best for the stakeholders" (p. 217). This requires disseminating information that allows stakeholders to make rational choices in their decision-making processes.

\subsubsection{Prospective versus Retrospective vision}

Prospective vision is one that looks beyond the actual crisis and focuses on what the future holds for the organization (Ulmer, Sellnow \& Seeger, 2011; Sellnow \& Seeger, 2013). In contrast, in a retrospective vision, organizations engage in blame tactics - there is a general tendency for communication to be more about looking back into what might have sparked the crisis with the intention of deflecting blame from the organization. The proponents of discourse of renewal point to the need for a "future-oriented' communication with the ultimate goal being to "rebuild rather than on issues of blame or fault" (Ulmer et al., 2011, p. 218). To communicate prospectively, organizational leaders are called upon to be "optimistic" about the future of the company in their communication. Optimism according to the proponents is an inevitable aspect of the discourse of renewal if communication that is prospective in nature must make sense during a crisis. As Ulmer et al., have argued, "[t]he discourse of renewal is inherently an optimistic form of communication and focuses on the ability of the organization to reconstitute itself by capitalizing on the opportunities embedded in a crisis" (p. 218). Sellnow and Seeger (2013) note that instead of focusing on the past and apportioning blame, "organizations committed to renewal direct their messages toward the ultimate goal of rebuilding the organization so that it is resilient to crisis" (p. 98). A reactive 
image and reputation restoration strategies clearly make way for a proactive and prospective communication.

\subsubsection{Organizational Learning}

Opportunities for learning following a crisis are also central to the renewal process (Ulmer, Sellnow, \& Seeger, 2007; Ulmer, et al, 2011; Sellnow \& Seeger, 2013). Proponents argue that when a crisis occurs, an organization's deficiencies, weaknesses, and strengths are exposed. Organizations are thus advised to communicate what they have learned in the aftermath of a crisis to increase the confidence level of stakeholders concerning the organization's ability to overcome future crises. In the renewal spirit, if stakeholders are to be aware that learning is happening, organizational leaders "should illustrate how the organization is learning from the crisis and what they are doing to ensure the crisis does not happen again" (Sellnow \& Seeger, 2011, p. 215).

Types of organizational learning include "behavioral", "systemic", and "paradigmatic" (Simon \& Pauchant, 2000, cited in Ulmer et al., p. 214). In behavioral learning, changes are not willingly enacted by the organization but come because of external forces and are therefore not "internalized" by the organization, but are rather "maintained through external control, through rules, regulations or technological systems" (Simon \& Pauchant, 2000, cited in Ulmer et al., 2011, p. 214). Behavioral learning is monitored and enforced by an external agency. Systemic learning occurs when an organization learns proactively or preemptively to avoid crisis. Paradigmatic learning involves changes integrated at all levels of the organization such that they offset previous basic business routine management and operational practices. These changes require 
consistent training of all employees. The changes are not a result of external agency intervention and must be enacted by the organization itself. Ulmer, et al. suggest organizations should aim at systemic learning because changes that emerge from this learning focus on preventing a crisis from occurring or reoccurring and are derived from organizational leadership commitment. The proactive or preemptive nature of these changes not only effectively shifts organizational focus from reactive image management concerns but offers long term benefits for the organization including opportunities for renewal.

\subsubsection{Effective Organizational Rhetoric}

Ulmer, Sellnow and Seeger (2011) explicitly state that the renewal model is "grounded in a larger framework of effective organizational rhetoric" (p. 219). As such, the renewal process "involves leaders structuring a particular reality for organizational stakeholders and publics" (p. 219). The purpose is to have stakeholders aligned with the organization's crisis response and increase their support for the organization during the crisis. To ensure that this happens, Sellnow and Seeger (2013) call on organizational leaders to "frame the crisis in a way that inspires, empowers and motivates" (p. 98). This advice draws on a social construction view of rhetoric; whereas a classical Aristotelian view holds that a rhetor must work within a pre-given reality, this view holds that rhetoric constructs reality. 


\subsection{Implication of renewal components for Crisis Communication}

The implication of the elements in the renewal model for the communication process can be perceived at several levels: (1) the organization is constituted as rhetorthe organization is entitized. (2) The leader or crisis communication professional acts as a corporate rhetor oriented towards the values, virtues, and goals of the organization which in turn determine the communication response to the crisis. (3) A leader-centric focus dominates the communication process during crisis response. I am aware that some organizations might have a decentralized/participatory management structure that routinely disseminates information and tasks, but it is the leader or the organizational crisis rhetor who is in-charge with "structuring" and "modeling" communication to achieve the behavior they "seek" from stakeholders during crisis (Sellnow \& Seeger, 2013, p. 98). (4) We clearly see a strong reference to classical Greco-Roman rhetoric where teachers of rhetoric such as Isocrates, Aristotle, Cicero, and Quintilian insisted on the potentials of the rhetor's character influencing the message's reception. A brief digression is warranted to explain this allusion.

In the ethical communication component of the discourse of renewal model, the overall focus on "positive values" of the organization as enacted by the crisis communicator/leader echoes the tensions and debates that gripped Classical GrecoRoman rhetoric about virtue especially concerning the rhetor's credibility as enacted through notions of "good sense", "good will" and/or "good moral character". According to Isocrates, "the technique of speech is neither morally good nor bad; only individuals are good and bad" (Kennedy, 1999, p. 41). Cicero and Quintilian later built on these 
ethical concerns to advance the image of the vir bona persona as a speaker's moral character and insisted that "only a good man can be a good orator" (Kennedy, 1999, p. 41). For Quintilian, "moral goodness" should remain the guiding principle for every orator. He argued that "the perfect orator should be a good man" (Book 2.15, 39-42). Kennedy (2007) has noted that "Aristotle shows a greater sense of urgency toward knowing and doing what is morally right" (p. 61). Concerns for ethical behavior are articulated in one of his three means of persuasion - ethos. The argument is that the credibility of the orator will facilitate whatever tasks she/he has set out to accomplish. This credibility is built partly on moral character; but Aristotle also claims that "the virtuous person makes a DECISION to do the virtuous action for its own sake" (Irwin, 1999, p. xviii). The bottom line is that communication was situated within the ability of the individual to influence her/his community, and this is heavily reflected in models of crisis communication.

However, in contemporary situations, a rhetor might merely just sound or look like a good person to influence public perception during crisis. Sellnow and Seeger sidestepped this argument when they noted that organizations that apply the discourse of renewal following a crisis "direct their messages toward the ultimate goal of rebuilding the organization so that it is resilient to crisis" (p. 98). It should be noted that it is the organization in the capacity of rhetor that designs its message while perhaps drawing from public or stakeholders' perceptions during a crisis with an obsessive focus on "rebuilding" - a key organizational goal necessary for organizational survival in times of crisis. 
In addition, worthy of note is the fact that when discussing ethical communication as a theoretical element, Ulmer et al. mentioned the need for the organizational rhetor to communicate in a provisional manner during a crisis. This conditional and at times spontaneous or improvisational communication is still heavily tied to the entity communicating. Provisional or improvisational communication is a product of the rhetor. It is the individual's uncanny ability to improvise under unusual circumstances that makes improvisation or provisional communication work - a clear reference to the classical Greek rhetorical concept of kairos or seizing the opportune moment or right timing. But kairos is particularly popular in relation to crisis as a rhetorical situation. The rhetorical situation according to Bitzer (1966) is a complex mix of "persons, events, objects, and relations presenting an actual or potential exigence which can be completely or partially removed if discourse, introduced into the situation, can so constrain human decision or action as to bring about the significant modification of the exigence" (p. 6). It is within this mix of inter-relations that kairos lends its strength to the rhetor allowing she/he to seize the "opportune moment" or "right timing" which Boer (2013) notes "appears unexpectedly" (p. 116). Kairos empowers the provisional rhetor as a leader responding to the opportunity of a crisis situation to frame realities, rework stakeholder relationships, and claim moral rectitude. Hence, even as the Discourse of Renewal redresses the reactive, defensive posture of earlier crisis rhetoric models and adopts a social constructionist metatheoretical frame, there remains a debt to classical GrecoRoman rhetorical concepts, particularly the vir bona tradition and the privileging of a corporate rhetor who embodies and extols values and virtues favored by targeted stakeholders. 
To counter these ideas about speaking and situation, I turn to postcolonial feminist theorist Gayatari Spivak.

\subsection{Spivak "Can the Subaltern speak?"}

Spivak's (1988) question “can the subaltern speak?" demonstrates the unequal power relations that define the struggle for the survival of indigenous epistemologies in a colonized context. While the colonized has always had to struggle to survive epistemologically, economically, politically, psychologically and materially, there is a level of paternalistic dependency that has been forced on the colonized by the colonizer. To break free from this domination, these power relations must be checked. There is need for the valorization of indigenous epistemologies, and the paternalistic dependency by the colonized on the colonizer has to be disrupted, if the subaltern must have agency in these power relations. The "epistemic violence" which Spivak clearly alludes to, is the outcome of repeating the circle of domination by postcolonial epistemologies that seek to "free" indigenous knowledge.

Spivak thus warns postcolonial scholars and other elite who have made it a project to counter imperialist discourses on marginalized communities to guard against creating reality for these silenced communities as this spirals back to the same imperialist discourses. This warning is not only for postcolonial critics and elites, but also to NGOs and groups spearheading campaigns to "protect" local or community interests or the interests of marginalized segments of that community. Speaking for marginalized people simply repeats the same silencing that oppresses and marginalizes these 
communities/segments. Instead, "speaking for" must be abandoned in favor of what she calls "unlearning": Spivak argued that "in seeking to learn to speak to (rather than listen to or speak for) the historically muted subject of the subaltern...[we] systematically unlearn [the subaltern]" (p. 295). In other words, to speak for the Other(s) draws on what we have learned about those who have been historically marginalized, ignored, and oppressed. Spivak warns against attempts from the outside to grant a form of collective speech to marginalized people, groups or communities as this often results in a logocentric suspension in favor of a certain unity or solidarity among diverse people, community, interests or goals.

\subsection{Globalization and Multinationals}

In this section of the chapter, I take a critical look at globalization with a greater focus on economic globalization and how multinational corporations are situated in global networks because the context of globalization provides a purview within which we could better understand the complex relations when applying the Discourse of Renewal. I pay particular attention to the manifestations of the global economic process in a bid to contextualize the multinationals within global relations through which we can better capture the drive behind multinational corporations' communication practices in developing countries - sub-Saharan Africa, in particular.

\subsubsection{Globalization}

Globalization is a contentious term. Critics see globalization as synonymous to imperialism - conquering, exploitation, and full-blown domination of developing, less 
powerful nations by imperialists like the US and the UK (e.g., Ikenberry, 2007;

Callinicos, 2007). But globalists have argued from the perspectives of the convergence thesis, which holds that interconnections among nations especially in economic terms lead to efficiency - hence economic growth for all nations involved in the process. Proponents agree that nations benefit from trade and financial openness (Mosley, 2007). For the globalists, this convergence is noticeable and applicable not only to the country's national policies, but also benefits the "lowest common denominator" (Mosley, 2007, p. 110), a result of an open-market competitiveness. Mosley (2007) argues that "competition reduces government's abilities to provide goods and services to their citizens, and it renders governments more accountable to external economic agents than to citizens of the polity" (p. 111). This is where divergent thesis theorists come in. Divergent theorists argue that "the global economy has placed governments, particularly in the developing world, in a 'golden straightjacket' [so they] must compete in order to survive, and the only means of competing is reducing government intervention, lowering taxes, and steadfastly pruning environmental, health and safety, and labor regulations" (Mosley, 2007, pp. 116-117). Mosley concludes that despite widespread support for the convergence thesis, "a cross-national, downward convergence of national policies has not occurred" (p. 121), meaning nation states have not witnessed widespread economic growth despite tying local economies to policies that favor global integration.

Neo-liberalism is also an important concept in discussions of globalization. Many scholars infer that economic globalization has simply been a transportation of neoliberalism to developing countries and that these poor nations have been significantly 
impacted (e.g. Harvey, 2006; El-Ojeili, 2006; Held \& McGrew, 2002). Critical approaches to neo-liberalism identify it with expanding opportunities for profitable capital accumulation (Harvey, 2006; El-Ojeili \& Hayden, 2006) involving global flows of corporate capital, finance, and trade, and subsequent stratifications and the commodification of the environment.

For Harvey (2006), neoliberalism emerged as a globalizing force to counter the "threats" which the structural crisis of the 1970s had on the "power of the upper classes"; as such neo-liberalism from the outset is understood to be a design to protect and restore "class power to the richest strata in the population" (Harvey, 2006, p. 13). To be clear, even though neo-liberalism, as Harvey (2006) puts it, "had long been lurking in the wings of public policy ... it was only during the troubled years of the 1970s that it began to move center stage, particularly in the US and Britain" (p. 15). Built along the lines of "free market, privatization of public assets, opening up natural resources to private exploitation and facilitating foreign direct investment and free trade" (Harvey, 2006, p. 12), neo-liberalism is perceived by critics as a machinery for the exploitation and widening of inequalities in relations between developed and developing countries. Tied to this neo-liberal agenda was a set of assumptions: privatization of state enterprises will lead to efficient management and improved performance; foreign direct investment should be promoted; deregulation of the economy is indispensable as is trade and financial liberalization, with interest rates determined by the market. But by insisting on reducing or removing barriers to international trade and minimal state control of the 
economy, globalization was paving the way for economic downturn of developing countries.

\subsubsection{Sub-Saharan Africa}

To substantiate these criticisms (economic) globalization, critics have looked at the impacts which international financial institutions, international trade organizations, and multinational corporations have on developing countries (e.g., Held, 2004; Anderson \& Cavanagh, 2000; Frynas, 2003, Harvey, 2006; El-Ojeili \& Hayden, 2006). I focus here on Sub-Saharan Africa. For example, El-Ojeili and Hayden (2006) argue that economic globalization (often tied to political and cultural global processes) has led to global inequalities among nations of the North and those of the South, among multinational corporations and citizens of developing countries - with heavy impact on Sub-Saharan Africa - involving expansive exploitation of developing countries by corporate and investment actors of richer economies including the US and Britain. These scholars see in globalization, "clear winners and drivers of corporate-led globalization" and they contest the notion of globalization as put forth by globalists "as a set of processes that move by themselves" (p. 88). This to El-Ojeili and Hayden is an ideology that secures the power and wealth of the industrialized world.

Many globalists think that globalization is unstoppable, and that any attempts to resist the movement will lead to devastating economic consequences, or as El-Ojeili \& Hayden put it, "economic woes" (p. 70). The global interconnectedness that has emerged from the global movement according to globalists has opened up opportunities for growth to every country. There are financial opportunities for everyone involved in the process, 
communication barriers reduced, technology transfer and more democratic governance, and free market systems that all add up to both private and public wealth of nations and citizens (see Friedman, 2005). The competitiveness of the free market is in fact a major justification for economic globalization. However, critics examine relations between international financial institutions - the IMF, World Bank, World Trade Organization and developing countries, as well as global financial flows, multinational operations, global inequalities, and the craze for profits on a global scale.

Critics argue that "the speed and uncontrollability of global financial flows is an urgent problem..." potentially displacing national economic and social sovereignty (ElOjeili \& Hayden, 2006). A telling case is the 1997 financial crisis that swept across Southeast Asia impacting countries like Thailand, Malaysia, and Indonesia. There was general fright among investors who quickly withdrew over $\$ 100$ billion and this led to currency depreciation in these countries. Turning to Sub-Saharan Africa following the 1970s worldwide financial crises, the IMF became a supervisory body for developing each country's economies, gauging performance, and insisting on the adoption of a free market system as a stringent condition for loans (see El-Ojeili and Hayden, 2006).

While neo-liberalists continue pushing for free and open market economies between developed and developing nations on grounds that competition and innovation are fostered under these conditions, Harvey (2006) insists that in practice free market ideology proved "to be the great vehicle for the consolidation of monopoly corporate and multinational powers as the nexus for class rule" (p. 18). This is especially the case given the hegemonic economic relations among the U.S. and Britain and developing countries 
despite the neo-liberal argument that poorer countries all have global opportunities to advance. For example, neo-liberal apologist Thomas Friedman (2005) argues that globalization incentivizes individuals to work ever harder in a "flat world" full of opportunities for all. Friedman not only noted how globalization is "empowering individuals," but asserted that the next stage of globalization, "globalization 3.0," was "not only going to be driven more by individuals but also by a much more diverse - nonWestern, nonwhite - group of individuals" (p. 34).

Critics however see disturbing inequalities in the manner in which the globalization movement has stratified the globe. About thirteen years ago scholars indicated the growing inequalities among people in the developed world and those in developing countries by pointing to disparate distribution of poverty. Perrons (2004, in El-Ojeili \&Hayden, 2006) explained that about 1.2 billion people survived on less than $\$ 1$ a day while 2.8 billion others lived on less than $\$ 2$ a day. Not much has changed as the World Bank's 2016 global poverty statistics show that 12.7 percent of the world's population lived at or below $\$ 1.90$ a day in 2012. The World Bank's statistics also indicate that developing countries are worst hit by poverty as over 2.1 billion people in the developing world lived on less than US $\$ 3.10$ a day in 2012 . The number of people living in "extreme" poverty in Sub-Saharan Africa has increased by 100 million more than the 284 million in 1990 -- that's 384 million people (Beegle, Christiaensen, Dabalen, \& Gaddis 2016). It is to be noted that Sub-Saharan Africa is just a region of the continent.

Malnutrition is widespread in developing countries. Between 2014 and 2016, the United Nations Food and Agricultural Organization estimates that 795 million people 
suffer chronic undernourishment in the world, and nearly all of these chronic undernourished cases - 780 million - live in developing countries. This means that most chronically undernourished people in the world are in developing countries. Moreover, the current available statistics for the Gross National Income per capita for the whole of Sub-Saharan Africa is $\$ 1,638$ billion, for a sub-continent of 973.4 million people, compared to the GNI per capita for countries in the Organization for Economic Cooperation and Development (OECD) which stands at $\$ 44,311$ billion (World Bank, 2016).

It can be argued that fundamental programs of neoliberal development have contributed to if not created the ongoing imbalances troubling world populations. In particular, the structural adjustment programs implemented by the IMF and World Bank as conditions for substantial national loans are suspect. These programs demand that recipient countries institute a move toward privatization of public assets and liberalization of all sectors of the economy. These conditions were imposed on developing African economies; when their loans became debts, these countries' most prized natural resources became open to capital appropriation by foreign companies including the extractive industries and agriculture sector. This brings me to the role of multinational corporations in the global neoliberal economy. 


\subsubsection{Multinational Corporations (MNCs)}

In discussing MNCs, my goal is to critique the activities of these corporations by highlighting the power (influence) they wield in the global economy, with a particular focus on developing economies in Sub-Saharan Africa. The overall focus will be to show how profits obsession drives the activities of these organizations (see Frynas, 2003; Pegg, 2003) and how this mode of conducting operations impacts MNCs' communication with stakeholders during crises.

The following characteristics define an MNC according to Cohen and Kennedy (2000, p. 121, cited in El-Ojeili \& Hayden, 2006): (1) control of economic activities in two or more countries, (2) ability to maximize the comparative advantage between countries, (3) benefits from endowments, wage rates, market conditions and political and fiscal regimes, (4) has geographical flexibility, that is an ability to shift resources and operations between different locations on a global scale, (5) operate through financial and operational flows among different segments of the MNC that are greater than the flows within a particular country, (6) has significant economic and social effects at a global level.

\subsubsection{MNCs' Dominance - Economic and Social}

Statistics from a World Bank blog post by Duncan Green (2016) show an increase in the number of corporations whose revenue is larger than most countries in the world (from 63 corporations in 2014 to 69 in 2015). Among these big companies are Walmart, Royal Dutch Shell, Exxon Mobil, Volkswagen, Toyota Motor, Apple, and BP. The Guardian newspaper correspondent Phillip Inman (2016), reporting on these findings, 
indicated that Walmart, Shell, and Apple "make more money than most countries in the world combined" (para. 4). The report added that 153 corporations are above many nations from Africa, Asia and South America. The annual revenue of many multinationals is larger than that of most African countries. For example, Royal Dutch Shell's revenue as reported in 2016 stands at $\$ 272$ billion compared to Nigeria's $\$ 54.48$ billion and Cameroon's $\$ 24.204$ billion. Shell has a GDP of $\$ 556$ - larger than that of any one country in Africa - including that of the two largest economies in Africa Nigeria (GDP is \$405 billion) and South Africa (GDP \$294.8). Other than the top 9 countries with the largest economies in the world - namely United States, China, Germany, Japan, France, United Kingdom, Italy, Brazil, and Canada - it is corporations that dominate the world's economy. This dominance is reflected in the paternalistic relationships sustained by these corporations with most countries. Phillip Inman (2016) cited a report by the charity Global Justice Now that highlighted this dominance. The report stated: "vast wealth and power of corporations is at the heart of so many of the world's problems - like inequality..." adding that "drive for short-term profits today seems to trump basic human rights for millions of people on the planet" (paras. 10-11).

Clearly, what this means is that not only is the global economy effectively controlled by multinationals, but the enormous power they wield around the globe is often oppressive.

\subsubsection{Foreign Investment}

MNCs expand their influence through Foreign Direct Investments (FDI) overseas investments by companies. These investments could involve purchasing or establishing income-generating assets in a foreign country that entails the control of the 
operation or organization. This can mean setting up subsidiaries or acquiring tangible assets in an overseas company. FDI is strategic in that it is not a passive form of investment like owning shares in another company, instead it actually offers "control" to the foreign company setting up the investment overseas (see World Bank; Financial Times Lexicon). In the case of sub-Saharan African countries, multinational corporations are able to wield economic and political power which often influences policy decisions of host governments in these countries, especially as many countries in Africa see these foreign investments as sources of revenue.

For decades, economic growth in Africa has "depended" on foreign direct investment (Bobo, 2005, p.15). As such, proponents of global trade see MNCs as indispensable for the provision of goods, services, and technical skills, plus their ability to provide revenue in company taxes, making the corporations necessary partners in economic growth and employment. The argument for globalists has been that development in Africa "can be best orchestrated through relations with the developed countries" (Bobo, 2005, pp. 13-14). A particular emphasis by globalists has been the notion that "through the diffusion of the developed world's capital, technology, values, and institutions to developing countries, a spawning of economic development will result" (Bobo, 2005, p. 14). But critics argue that the relations between developed and developing countries have been that of the usurper and usurped. Other critics (e.g., Bobo, 2005) have taken a somewhat middle-ground by arguing that relations between developed and developing countries is rather a "give-and-take" - that's the relationship benefits both parties, although the argument holds that the benefits are 
"disproportionately" shared such that much of the gains realized in economic operations are "skewed" (p. 14) into the developed countries. At the center of this practice are multinational corporations (Bobo, 2005). In fact, it appears impossible to talk of development in economic terms by trying to separate developed countries from MNCs, because multinationals are the drivers of these same countries' economic growth.

\subsection{Colonialism and Neocolonialism}

\subsubsection{Legacies of Colonialism}

Scholars have explained colonial experiences as forces that transformed ethnic groups in Africa, although they also argue that contemporary ethnic groups in Africa have further been modified by processes beyond the colonial era. Pelican (2015) has argued that "many aspects of traditional organization, history and legal arrangements in contemporary Africa are not based on locally developed customs, but were the outcome of colonial subjects" (p. 49). But Pelican suggested it would be a misconception to completely wipe out the influence which early traditions in Africa still have on current organizing practices in African communities. For example, in his analysis of "tradition" and "custom" in Cameroon, Pelican (2015) found that tradition commonly referred to as "country fashion," to Cameroonians, denotes "practices inherited from previous generations and still relevant in everyday life, and therefore variable and adaptable to contemporary situations" (p. 49); whereas custom refers to "practices and procedures introduced or fixed by colonial authorities" (p. 49). The bottom line is that contemporary characterizations of African societies cannot neglect colonialism and neocolonial experiences as forces that transform organizing (i.e., ways of doing) in Africa, but at the 
same time, such characterizations must not ignore those practices inherited from earlier practices that are still relevant and adaptable to contemporary circumstances in African communities.

Colonialism according to Mudimbe (1988) was an implantation of a "colonizing structure" that was at once "the domination of physical space, the reformation of natives' minds, and the integration of local economic histories into the Western perspective" (p. 15). Mudimbe insists this colonizing structure was responsible for "producing marginal societies, cultures, and human beings" (p. 4) through its "policies of domesticating natives" (p. 2). No aspect of native life was left unaffected by the colonial encounter. Even the local economic practices of the natives were assimilated into the colonialists' capitalist economic systems. The African traditional religion was permeated by the colonizing experience. New spiritual values were transmitted through churches that were established by missionaries. The colonial educational system and the colonial press were also effective mediums for reforming the minds of natives: "new attitudes" considered "contradictory" to so-called African traditional ways of life were transmitted to the local people (Mudimbe, 1988). The short and long-term impact of this experience, according to Mudimbe, was the trivialization of those core values that appeared to define native life and personhood including mode of worship and organizing.

The "new culture" that emerged from the colonial "transformations" led to the "rejection [by the colonial structure] of unadapted persons and confused minds" (Mudimbe, 1988, p. 4). To survive and remain useful in the new environment created by the colonial experience, the natives had to integrate themselves into what Mudimbe calls 
"intermediate space between" (p. 5). The "intermediate space between" is a marginal space in which interaction occurred between the African tradition and the implanted colonial culture. To survive in this space was to live at a borderline, a life that adapts to emergent cultural and social environments in a non-totalizing manner in order to be useful to therein. Colonial experiences are succinct examples of how the "subaltern" was deliberately silenced through representations that created new realities for communities.

Indirect rule was a policy in which the British colonialists used local chiefs "to implement colonial policies" (Jua, 1995, p. 39). This policy was very active in the Southern Cameroons also referred to as British Cameroon and in Nigeria. Jua (1995) notes that in Cameroon, while the policy of indirect rule "served to create the requisite enabling environment" for "maximum economic exploitation" (p. 39), the policy seen as "cultural imperialism" (p. 39) also led to the "redefinition of power relations" and the "invention of tradition" (p. 41) by the British. African traditional institutions were weakened, indigenous modes of organizing disrupted, and power now flowed through a centrifugal structure. Indirect rule also saw the British blending the colonial administration with local chiefs and other elites schooled in the colonial education system, even though this blending didn't reflect a robust participatory process capable of empowering the natives. In Cameroon and Nigeria, chiefs were appointed as Native Authorities, while Africans who emerged from the colonial education establishment were integrated into the British colonial administration. This process has been described by some African scholars as "Africanization" (e.g., Jua, 1995; Chilver, 1963). This form of Africanization emerged in 1948 for the Southern Cameroons as a policy within the 
indirect rule framework. By Africanization, the British were transforming the already established colonial administration into an "improved system of Native Administration and local government" (Chilver, 1963, p. 129).

French African colonies for their part saw an implementation of the policy of assimilation. Assimilation was a French ideology set out to expand the French culture and language as Africans in French colonies were taught that by "adopting the French culture and language" they could "become French" which from the perspectives of colonialists was a privilege (Sesan, 2014, p. 2). The outcome of this policy in these colonies was "high disregard" for African religious orientation and beliefs, natives' culture, traditional institutions, and power structures. The chiefs' power was weakened through this tactic to disempower what was indigenous African authority (Sessan, 2014, p. 6). For the disruption of native institutions, belief systems and power relations to be effective, a colonial structure in which communication was initiated, produced, and disseminated by the colonialists was established. Local chiefs and other African elites carried the information from colonialist administrative agencies to the local people and from communities to the colonialists. The colonial administration then tailored the information to the exact goals and impact desired by the colonial government and then, retransmitted to the local people through this network of chiefs or "extension officers" (AnsuKyeremeh, 1997).

As mentioned already, this colonial history relating to the British and French policies of indirect rule and assimilation is important because it allows us to see how the colonial encounter heavily contributed to the production of hybridized experiences. Jua 
(1995) has consistently argued that indirect rule was actually the creation of new ways of life that contradicted what appeared to be the norms in African traditions. In so doing, the policies of indirect rule, and assimilation transformed the social space within which cultures met, and in which the local people, and arguably, the colonialists too, had to negotiate new ways of being if they were to remain relevant to the new social space that emerged.

\subsubsection{Contexts of Neocolonialism}

The post-colonial African states that emerged sustained the legacy of colonialism (Jua, 1995). The African elites who served the colonial administration and were now in top government positions remained determined to reproduce colonial structures to protect their political, social, and economic power. For these elites, it was not necessarily a question to return to the celebrated precolonial past but to rather fortify the colonial legacy. In Cameroon, for example, chiefs continue to serve as "auxiliaries" acting as "intermediaries" between the administration and the people by carrying out government directives (Jua, 1995, pp. 42-43). The top-down colonial communication structures were also vigorously maintained.

The Shell crisis in the Niger Delta region of Nigeria, and the Herakles Farms crisis in the Southwest region of Cameroon cannot be separated from these neoliberal relations and free market concepts. In both crises, the companies, host governments, and local elites were charged with capitalistic corruption. Permeated by corrupt practices, these companies' relations with communities resulted in a divide among local populations and their elites, as well as traditional rulers. Personal economic gains took 
precedence in negotiations between leaders of these communities and the corporations. As a result of this situation in the sub-Saharan region, Fomin and Forje (2005) have argued that after many years of colonialist and neocolonialist exploitation of these riches [minerals, crude oil reserves, land], little or nothing is there in terms of development, to attest to the tremendous wealth that foreign imperialists and their African collaborators have looted from the whole sub-region.

Critics of multinationals have noted that their presence in many developing countries exerts too much power in their relations with developing nations, and most especially with local communities. In addition, MNCs too often evade taxes, exploit local communities, and can relocate to other lands if they think it will serve their best interests. Optimists (as indicated in Cameroon's Vision 2035) argue that by being active in international markets that foster strong relationships with multinational corporations, African nations will be able to acquire sufficient revenue to develop their own economies and increase production of goods for both national and international consumption. However, Lanning and Mueller (1979) examined the mining industry in Africa and insisted that development in African countries has been undermined noting that "Africa's mineral resources are being depleted without generating economic development" (p. 485). These scholars noted that "control of the mineral exports is firmly in the hands of the mining companies, who exploit the mineral resources at a rate and in a manner consistent with their interests and not with those of the host nation" (pp. 485-486). As mentioned already, this trend of doing business in Sub-Saharan Africa has been affecting all sectors of economic operations in which MNCs are also major partners. 
The main argument in this chapter has been that the Discourse of Renewal must be responsive to complex contexts that frame rhetoric. These contexts are enmeshed in differential patterns of communication, exigencies, and complex relations. The discussion on globalization, neoliberalism, colonialism and MNCs provided a purview into the interpenetrating contexts that complicate crisis rhetoric in transcultural settings.

The following chapter explains the data, coding, and thematic analysis that inform my case studies. 


\section{Methodology}

\subsection{Introduction}

This dissertation compares two cases to illuminate the limitations and need for the amendment of the renewal model of crisis communication. These cases can suggest how the management of crisis by MNCs in non-Western contexts are shaped by specific African cultures and histories. So, bringing together lessons from these cases can in turn inform the amendment of the renewal model. Further, these cases are used in this research as a way to organize data and findings. This chapter details the data, coding, and thematic analysis that informs each case.

Data and analyses in this research aimed at answering the research questions I introduced in Chapter 1:

RQ1: What are the limitations of the Crisis Renewal model for multinationals operating in West African countries?

RQ2: How can this model be amended based on African communication principles?

\subsection{Rationale for Cases}

Cases are widely applied in crisis communication research. The current renewal model developed through case analyses (Seeger \& Ulmer, 2001, 2002; Seeger et al., 2005; Ulmer, 2001; Ulmer \& Sellnow, 2002). The method of case analysis that examines contemporary complex phenomenon in real-world contexts makes case analysis a suitable 
research method (Yin, 1994, 2004, 2009). However, crisis communication scholars do not develop cases as a method of analysis but rather employ modes of rhetorical analysis that apply concepts of classical rhetoric (apologia) or psychological processes (attribution) to the exigencies of a corporate crisis. Theoretical components of a crisis communication model are applied to ongoing or post crisis communicative processes of organizations, institutions, or entities as ways of investigating the salient issues.

The case development in crisis communication is descriptive and the analysis proceeds deductively by fitting the rhetorical model to the description of the case. However, these models were developed inductively by examining cases of corporate crises to identify rhetorical strategies. Thus, the image repair model has been expanded by examining particular cases for additional elements of classical apologia. Similarly, the discourse of renewal model was developed by identifying affirmative, responsive strategies in particular exemplars of corporate crisis response.

\subsection{Data and Procedure}

\subsubsection{Data Sources}

There were two sets of data. The first set was data about the Shell oil crisis in Nigeria and the second set was data about the Herakles' Farms crisis in Cameroon. For the Nigerian case data sources included newspaper reports and radio texts, company documents (e.g., environmental impact assessment reports, mission and value statements, ethical code of conduct statements, press releases, and statements on Shell's website as well as news releases and reports from NGOs and Civil Society Organizations directly 
involved in the crises). The reports came from local Nigerian and international newspapers and wire services. The radio texts were specifically from the BBC World Service. Three hundred and ninety-one (391) documents were collected on the Nigerian case. The time frame for the crisis in Nigeria runs from 1993 through 2016. The Niger Delta oil crisis involving Shell, the Nigerian government, and local communities has a long history. However, this study is limited to documents between 1993 and 2016. This timeframe reflects the most intense moments in the crisis cycle; international attention was drawn to the crisis during these years. The crisis is ongoing.

Data sources for Herakles Farms crisis in Cameroon include Open Letters published by the company in direct response to accusations. These letters were found on the websites of Oakland Institute, Business and Human Rights Resource Center, Herakles Farms, and Greenpeace. Other documents include a letter to investors, Investment Opportunity document; Herakles Farms' Value Drivers document also accessed via the website of Oakland Institute; Herakles Farms' Environmental Social Impact Assessment Report downloaded from the NGO Center for the Environment and Development; letters of opposition from communities; and newspaper reports (downloaded from LexisNexis). There were reports published by the international NGOs mentioned in this case. There were also five news videos accessed via YouTube and Facebook page of the journalist who produced the report. I later transcribed these news feeds. Herakles Farms crisis time frame is 2009 to 2016 . A total of 91 documents were found to be relevant for the analysis in the Herakles Farms case. 


\subsubsection{Data Collection Strategies and Organization}

For both cases, newspaper reports and radio texts were downloaded from the online database LexisNexis. Online searches were also made on Google Search Engine. Preliminary searches using words relating to the crises in Nigeria and Cameroon resulted in massive search results. For the crisis in Nigeria, terms such as Ogoni crisis, Ogoni oil, Ken Saro-Wiwa, Ogoni shell protests, Ijaw oil crisis, Itsekiri oil, MOSOP, Niger Delta killings, Niger Delta crisis, Shell Nigeria crisis, Nigeria oil spills, and Nigerian government oil protests, appeared to generate the most data. Following are search results when these terms are entered on LexisNexis: Ogoni crisis (705 items), Ogoni oil (996 items), Ogoniland (995 items), Niger Delta crisis (991 items), Nigerian oil spill (996 items found), MOSOP (998 items), Shell Nigeria crisis (998 items), Ken Saro Wiwa (997 items), Nigerian government oil protests (996 items), Ijaw oil crisis (731 items), Itsekiri oil (718 items). Repeated searches found that many of these items were duplicates as different newspapers simply republished reports that other reporters already published. This was a particular trend noticed with some local Nigerian Newspapers. Relevant documents were also downloaded from the websites of Shell Global, SPDC, Ministry of Niger Delta Affairs, and Niger Delta Development Commission, and NGOs involved in the crisis.

This same search strategy was applied to the Herakles Farms case in Cameroon. Some key terms used include: Herakles farms, Palm oil crisis Cameroon, Cameroon palm plantation, Herakles crisis. Since the website of Herakles farms was no longer available at the time of data collection, most search results came from local and international 
including NGOs Center for the Environment and Development, Struggle to Economize Future Environmnet (SEFE), Oakland Institute, Green Peace International, Human Rights Watch as well as online Google searches that provided links to some newspaper reports not found on LexisNexis.

The next step was to organize the data. For the Nigerian case data types include: (a) Newspaper reports, (b) Government documents, (c) Royal Dutch Shell documents, (d) NGO reports. Data types for the case in Cameroon include: (a) Cameroon Government dossier, (b) Communities opposition, (c) NGO reports, (d) News reports.

Once organized into types, data was collected based on the characteristic communicative organization of each type. For example, a preliminary scan of 'headlines' for the newspaper reports proved to be effective. Headlines are important parts of every news story and headlines effectively provide hints on the most important content of the story. I also read the "lead", "graph" or opening paragraph of the news reports to further ascertain the focus of the news item. The lead is an important part of every news report as it summarizes the most important information in a news story. News stories normally follow an inverted pyramid approach widely taught in journalism. According to this approach, a news story begins with the most important information to the least - but this rule might not always be the case in every news story - a direct consequence of news organization's or journalist's judgement (including organizational and personal bias). Aware of this, the first two paragraphs of each news story was scanned through before the item was selected. The first paragraph in a newspaper story called "lead" or "graph" is considered the most important portion of the entire news story because that is where 
the reporter highlights the most important aspects of the story. A similar process was applied to company and NGO documents, and government documents. I then read the whole article for coding.

\subsection{Coding approach}

In this dissertation, both focused coding and first cycle coding methods are applied. Focused coding was most appropriate when coding statements made by organizational leaders and spokespersons since coding categories were already known to be the four theoretical dimensions of the Discourse of Renewal. Focused coding is most appropriate at the level of organizing data into categories (Saldana, 2009; Tracy, 2013; Boyatzis, 1998); and since the four theoretical components are the frames of analysis in the amendments I offer to the model, it was logical to begin coding at this level.

However, when coding statements made by villagers, community leaders and/or representatives of local communities as they responded to the two multinationals' messages, the process began with initial coding and then progressed to focused coding (see Tracy, 2013). The rationale for this was that I was looking for themes from the point of view of local communities and these had to emerge from the data.

\subsubsection{Coding process}

Coding corporate crisis communication was based on the dimensions of either the apologia model or the discourse of renewal. I was looking for words, phrases, or sentences in statements made by organizational leaders and spokespersons about the crisis that were closest to the theoretical premises provided in the model. Categorizing 
these codes required making judgements not just on the use of these words, phrases or sentences, but also in relation to the context in which these codes are used. Meanwhile, when coding statements by local communities in response to corporate crisis communication or to other stakeholders in the crisis, emphasis was on identifying themes specific to these responses.

The overall coding process proceeded as such: I read the statements line-by-line repeatedly and coded them by identifying either those words, phrases, or sentences that addressed the four theoretical dimensions or the words, phrases, and sentences that were recurrent, given emphasis, and/or phrased forcefully in communities' response (Owen, 1984). The purpose for doing this was for me to be able to identify potential data belonging to a particular theme or category. The next step was to critically examine the codes identified and then to organize them into themes or categories. Codes that reflected each of the four theoretical dimensions of the discourse of renewal were pattern-matched to the premises of the model. Codes that emerged out of my examination of responses to corporate rhetoric were later reframed in terms of Africentric communication concepts.

\subsubsection{Conceptualizing and Operationalizing Categories}

The conceptual explanations of each of the categories are based on the theoretical explications provided in the model. I then inductively provided operational definitions for each of the categories. In doing so, I provided examples of what is included and what is not included in each category (See Table 1) For communities' response, the focus was on themes. I discuss themes in the "thematic analysis" section in this chapter. 
Table 1. Coding Categories (Discourse of Renewal)

\begin{tabular}{|c|c|c|c|c|}
\hline Categories & $\begin{array}{l}\text { Conceptual } \\
\text { Definitions }\end{array}$ & $\begin{array}{l}\text { Operational } \\
\text { Definition }\end{array}$ & $\begin{array}{l}\text { Example of } \\
\text { what is } \\
\text { included }\end{array}$ & $\begin{array}{l}\text { Example of } \\
\text { what is not } \\
\text { included }\end{array}$ \\
\hline $\begin{array}{l}\text { Ethical } \\
\text { Communication }\end{array}$ & $\begin{array}{l}\text { Organizational } \\
\text { leaders and } \\
\text { spokespersons } \\
\text { communicate in } \\
\text { ways that show } \\
\text { the organization } \\
\text { aligns with } \\
\text { strong, positive } \\
\text { value positions } \\
\text { with } \\
\text { stakeholders, } \\
\text { such as honesty, } \\
\text { responsibility, } \\
\text { accountability, } \\
\text { and } \\
\text { trustworthiness. } \\
\text { This category } \\
\text { suggests that by } \\
\text { doing so, an } \\
\text { organization is } \\
\text { able to attain } \\
\text { renewal. }\end{array}$ & $\begin{array}{l}\text { Word, phrase, } \\
\text { or sentence } \\
\text { that alluded or } \\
\text { directly } \\
\text { referred to } \\
\text { ethical } \\
\text { components } \\
\text { discussed in } \\
\text { the conceptual } \\
\text { explication of } \\
\text { the category. } \\
\text { Attention to } \\
\text { the context in } \\
\text { which these } \\
\text { statements } \\
\text { appear is } \\
\text { necessary. }\end{array}$ & $\begin{array}{l}\text { Shells "seeks } \\
\text { to increase } \\
\text { transparency } \\
\text { and } \\
\text { accountability } \\
\text { around project } \\
\text { delivery and } \\
\text { give } \\
\text { communities } \\
\text { greater } \\
\text { ownership of } \\
\text { projects from } \\
\text { their } \\
\text { inception." } \\
\text { Herakles: } \\
\text { "Going } \\
\text { forward, we } \\
\text { want to foster } \\
\text { greater } \\
\text { openness, } \\
\text { transparency } \\
\text { and } \\
\text { collaboration } \\
\text { in our } \\
\text { activities" }\end{array}$ & $\begin{array}{l}\text { Any word, } \\
\text { phrase or } \\
\text { sentence used } \\
\text { by leaders } \\
\text { and } \\
\text { spokesperson } \\
\text { s NOT } \\
\text { directly } \\
\text { related to this } \\
\text { category. }\end{array}$ \\
\hline $\begin{array}{l}\text { Prospective vs. } \\
\text { retrospective } \\
\text { vision }\end{array}$ & $\begin{array}{l}\text { Organizational } \\
\text { leaders and } \\
\text { spokespersons } \\
\text { focus } \\
\text { communication } \\
\text { on looking } \\
\text { "beyond" the } \\
\text { crisis, moving } \\
\text { away from } \\
\text { issues of blame }\end{array}$ & $\begin{array}{l}\text { Word, phrase, } \\
\text { or sentence } \\
\text { evoking a } \\
\text { future-oriented } \\
\text { communicatio } \\
\text { n i.e., focusing } \\
\text { on a future of } \\
\text { growth, } \\
\text { renewal, and } \\
\text { progress. }\end{array}$ & $\begin{array}{l}\text { "Shell remains } \\
\text { in the forefront } \\
\text { of converting } \\
\text { Nigeria's oil } \\
\text { and gas } \\
\text { resources to } \\
\text { more jobs and } \\
\text { opportunities } \\
\text { for Nigerians." }\end{array}$ & $\begin{array}{l}\text { Any word, } \\
\text { phrase or } \\
\text { sentence used } \\
\text { by leaders } \\
\text { and } \\
\text { spokesperson } \\
\text { s NOT } \\
\text { directly } \\
\text { related to this } \\
\text { category. }\end{array}$ \\
\hline
\end{tabular}




\begin{tabular}{|c|c|c|c|c|}
\hline & $\begin{array}{l}\text { and fault, into an } \\
\text { optimistic future. }\end{array}$ & & $\begin{array}{l}\text { Herakles: "in } \\
\text { the future we } \\
\text { plan to spend } \\
\text { about } 29 \\
\text { billion" } \\
\text { efforts to } \\
\text { developing the } \\
\text { plantations in } \\
\text { a sustainable } \\
\text { manner }\end{array}$ & \\
\hline $\begin{array}{l}\text { Effective } \\
\text { Organizational } \\
\text { Rhetoric }\end{array}$ & $\begin{array}{l}\text { Organizational } \\
\text { leaders and } \\
\text { spokespersons } \\
\text { communicativel } \\
\text { y frame the } \\
\text { crisis in a way } \\
\text { that inspires, } \\
\text { empowers and } \\
\text { motivates, such } \\
\text { that stakeholders } \\
\text { can make } \\
\text { informed } \\
\text { decisions. It } \\
\text { involves } \\
\text { structuring } \\
\text { reality for } \\
\text { stakeholders. }\end{array}$ & $\begin{array}{l}\text { Word, phrase, } \\
\text { or sentence } \\
\text { used by leaders } \\
\text { and } \\
\text { spokesperson } \\
\text { that focuses on } \\
\text { transcendence, } \\
\text { and with a } \\
\text { motivational } \\
\text { appeal. }\end{array}$ & $\begin{array}{l}\text { Gas and Oil } \\
\text { project is } \\
\text { "good news for } \\
\text { Nigeria"; the } \\
\text { project } \\
\text { "strengthens } \\
\text { Nigeria's deep- } \\
\text { water } \\
\text { expertise" and } \\
\text { is a "key driver } \\
\text { of economic } \\
\text { development." } \\
\\
\text { Herakles: } \\
\text { "encouraging } \\
\text { small scale } \\
\text { holders to } \\
\text { develop } \\
\text { individual } \\
\text { farms to } \\
\text { become an } \\
\text { integral part of } \\
\text { the palm } \\
\text { project" }\end{array}$ & $\begin{array}{l}\text { Any word, } \\
\text { phrase or } \\
\text { sentence used } \\
\text { by leaders } \\
\text { and } \\
\text { spokesperson } \\
\text { s NOT } \\
\text { directly } \\
\text { related to this } \\
\text { category. }\end{array}$ \\
\hline $\begin{array}{l}\text { Organizational } \\
\text { Learning }\end{array}$ & $\begin{array}{l}\text { Organizational } \\
\text { leaders and } \\
\text { spokespersons } \\
\text { communicate } \\
\text { lessons learned }\end{array}$ & $\begin{array}{l}\text { Word, phrase, } \\
\text { or sentence } \\
\text { used by leaders } \\
\text { and } \\
\text { spokesperson }\end{array}$ & $\begin{array}{l}\text { "The overall } \\
\text { purpose [of the } \\
\text { GMOU] was to } \\
\text { eliminate the } \\
\text { inherent }\end{array}$ & $\begin{array}{l}\text { Any word, } \\
\text { phrase or } \\
\text { sentence used } \\
\text { by leaders } \\
\text { and }\end{array}$ \\
\hline
\end{tabular}




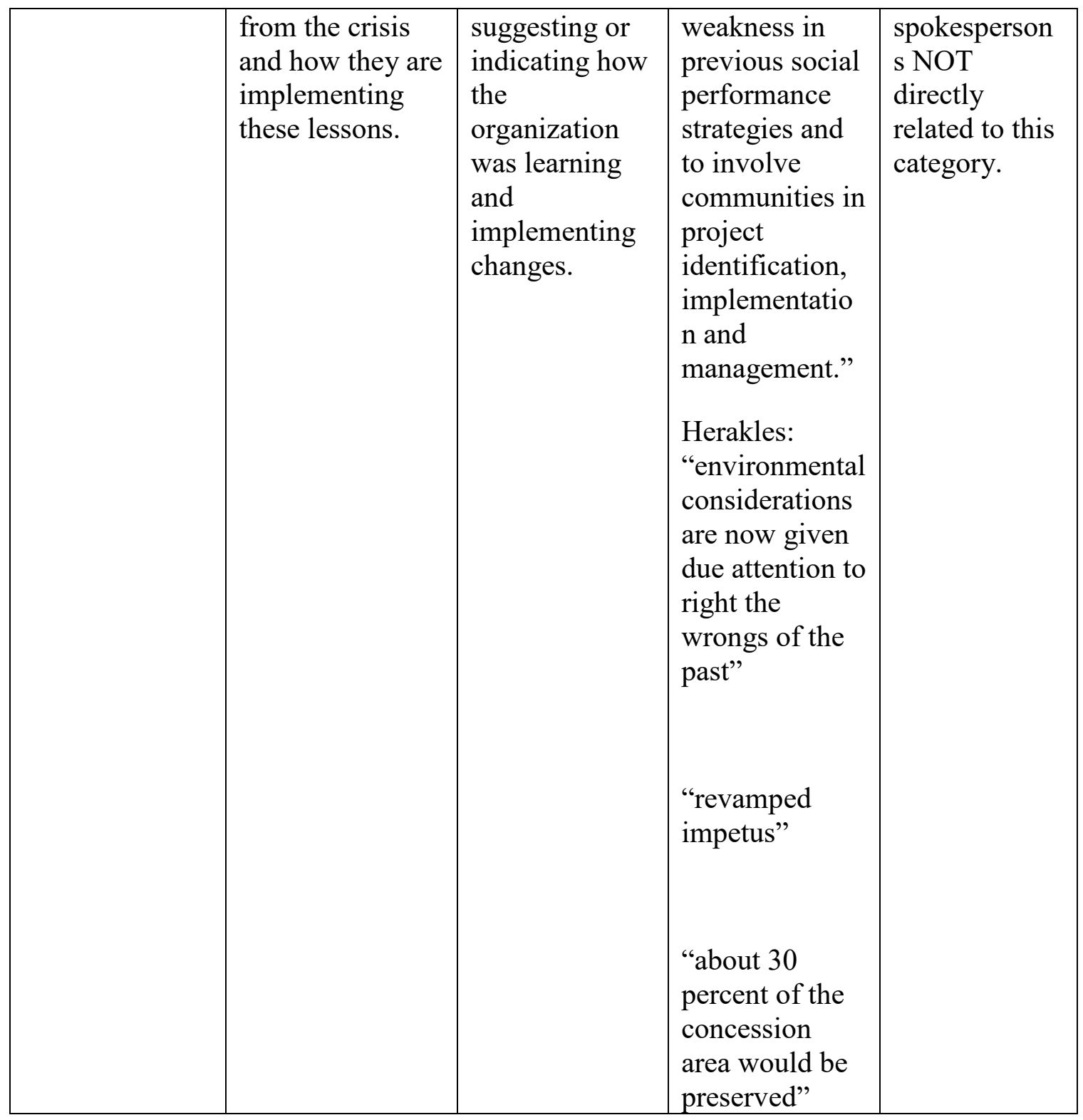

\subsection{Unit of Analysis}

The unit of analysis was specific statements made during and about the crisis drawn from data sources. The four theoretical dimensions that inform the Discourse of Renewal model served as frames of analysis. However, this dissertation also analyzed the early communication of the two multinationals to provide a comparative frame regarding 
the shift in communication strategies - from defensive/reactive to proactive/renewal. To do this, Benoit's (1995/1997) five typologies informed by Apologia were the frames of analysis. The unit of analysis constituted direct statements from company leaders and spokespersons about the crisis.

\subsection{Thematic analysis}

This section focuses on communities' response to the Discourse of Renewal applied by the two multinationals. It was important to code themes because from these themes, it would be possible to fully understand the concerns of local communities and point to possible areas of amendments in the Discourse of Renewal.

Boyatzis (1998, p. 31) identified five elements that constitute a rigorously coded theme:

(1) a label, that is, a name; (2) explanation of what constitutes the theme; (3) description of how to know when the theme occurs; (4) description of what is not included in the theme; (5) examples of what is included and what is excluded from the theme. Following the second cycle coding in which the focus was to regroup recurrent codes for thematic analysis, I was able to identify major themes that emerged from communities' response to Shell's and Herakles' communication (see table 2). 
Table 2. Themes in Communities' Response to Shell's Discourse of Renewal

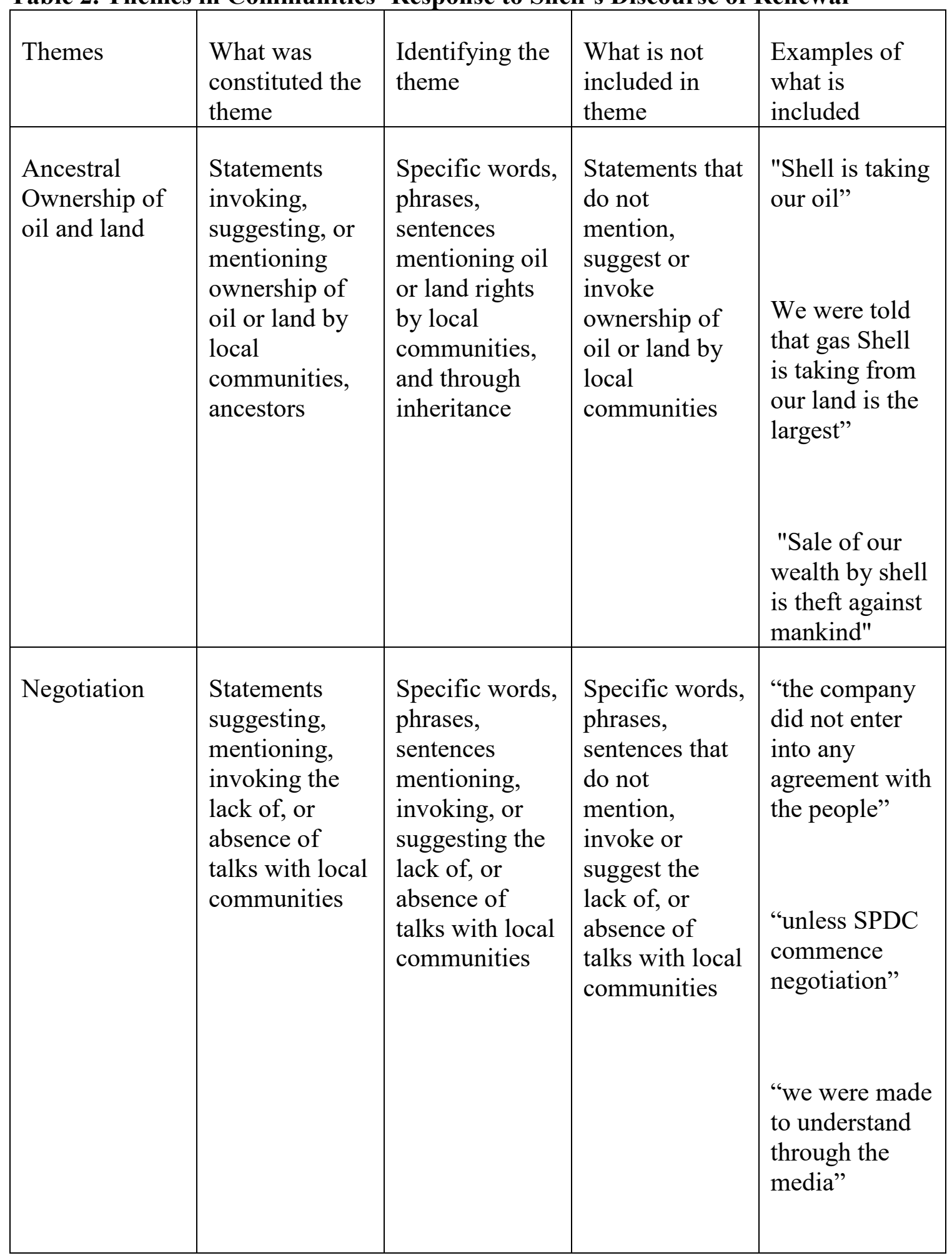




\begin{tabular}{|c|c|c|c|c|}
\hline & & & & $\begin{array}{l}\text { "should Shell } \\
\text { fail to } \\
\text { commence } \\
\text { negotiation" }\end{array}$ \\
\hline Leadership & $\begin{array}{l}\text { Statements } \\
\text { invoking } \\
\text { mentioning, or } \\
\text { suggesting } \\
\text { local } \\
\text { communities } \\
\text { not properly } \\
\text { represented; } \\
\text { statements } \\
\text { suggesting the } \\
\text { company } \\
\text { leaders } \\
\text { handpick locals } \\
\text { on behalf of } \\
\text { communities }\end{array}$ & $\begin{array}{l}\text { Specific words, } \\
\text { phrases, } \\
\text { sentences that } \\
\text { suggest, } \\
\text { invoke, or } \\
\text { mention local } \\
\text { communities } \\
\text { not properly } \\
\text { represented; } \\
\text { statements } \\
\text { suggesting the } \\
\text { company } \\
\text { leaders } \\
\text { handpick locals } \\
\text { on behalf of } \\
\text { communities }\end{array}$ & $\begin{array}{l}\text { Specific words, } \\
\text { phrases, } \\
\text { sentences that } \\
\text { do not suggest, } \\
\text { invoke, or } \\
\text { mention local } \\
\text { communities } \\
\text { not properly } \\
\text { represented; } \\
\text { statements not } \\
\text { suggesting the } \\
\text { company } \\
\text { leaders } \\
\text { handpick locals } \\
\text { on behalf of } \\
\text { communities }\end{array}$ & $\begin{array}{l}\text { "Shell invited } \\
\text { some few } \\
\text { unauthorized } \\
\text { members of } \\
\text { affected } \\
\text { communities" } \\
\text { "our said } \\
\text { representative" } \\
\text { SPDC has } \\
\text { refused to give } \\
\text { opportunities } \\
\text { to our } \\
\text { contractors }\end{array}$ \\
\hline $\begin{array}{l}\text { Illegal } \\
\text { partnership }\end{array}$ & $\begin{array}{l}\text { Statements } \\
\text { invoking, } \\
\text { suggesting or } \\
\text { mentioning oil } \\
\text { company not } \\
\text { signing legal or } \\
\text { binding } \\
\text { agreements } \\
\text { with local } \\
\text { communities }\end{array}$ & $\begin{array}{l}\text { Specific words, } \\
\text { phrases, } \\
\text { sentences that } \\
\text { suggest, } \\
\text { invoke, or } \\
\text { mention oil } \\
\text { company not } \\
\text { signing legal or } \\
\text { binding } \\
\text { agreements } \\
\text { with local } \\
\text { communities }\end{array}$ & $\begin{array}{l}\text { Words, } \\
\text { phrases, } \\
\text { sentences that } \\
\text { do not suggest, } \\
\text { invoke, or } \\
\text { mention oil } \\
\text { company not } \\
\text { signing legal or } \\
\text { binding } \\
\text { agreements } \\
\text { with local } \\
\text { communities }\end{array}$ & $\begin{array}{l}\text { "Shell has not } \\
\text { shown any } \\
\text { interest to have } \\
\text { a GMoU with } \\
\text { Uzere } \\
\text { kingdom" }\end{array}$ \\
\hline
\end{tabular}




\begin{tabular}{|c|c|c|c|c|}
\hline & & & & $\begin{array}{l}\text { with the cluster } \\
\text { communities" }\end{array}$ \\
\hline $\begin{array}{l}\text { Shortchanging } \\
\text { communities }\end{array}$ & $\begin{array}{l}\text { Statements } \\
\text { invoking, } \\
\text { suggesting or } \\
\text { mentioning oil } \\
\text { companies not } \\
\text { providing } \\
\text { valuable social } \\
\text { amenities for } \\
\text { local } \\
\text { communities }\end{array}$ & $\begin{array}{l}\text { Words, } \\
\text { phrases, } \\
\text { sentences } \\
\text { invoking, } \\
\text { suggesting or } \\
\text { mentioning oil } \\
\text { companies not } \\
\text { providing } \\
\text { valuable social } \\
\text { amenities for } \\
\text { local } \\
\text { communities }\end{array}$ & $\begin{array}{l}\text { Statements not } \\
\text { invoking, } \\
\text { suggesting or } \\
\text { mentioning oil } \\
\text { companies not } \\
\text { providing } \\
\text { valuable social } \\
\text { amenities for } \\
\text { local } \\
\text { communities }\end{array}$ & $\begin{array}{l}\text { "deny the } \\
\text { community } \\
\text { potable water, } \\
\text { health centre, } \\
\text { light, and } \\
\text { adequate intra } \\
\text { community } \\
\text { roads" } \\
\text { "requests for } \\
\text { construction of } \\
\text { streets/roads } \\
\text { fell on deaf } \\
\text { ears" } \\
\text { "refusal of } \\
\text { SPDC to } \\
\text { provide road } \\
\text { and power } \\
\text { generating } \\
\text { projects" }\end{array}$ \\
\hline
\end{tabular}

Table 3. Themes in Communities' Response to Herakles Farms' Discourse of Renewal

\begin{tabular}{|l|l|l|l|l|}
\hline Themes & $\begin{array}{l}\text { What } \\
\text { constitutes the } \\
\text { theme }\end{array}$ & $\begin{array}{l}\text { Identifying the } \\
\text { theme }\end{array}$ & $\begin{array}{l}\text { What is not } \\
\text { included in the } \\
\text { theme }\end{array}$ & $\begin{array}{l}\text { Examples of } \\
\text { what is } \\
\text { included }\end{array}$ \\
\hline $\begin{array}{l}\text { Ancestral land } \\
\text { rights }\end{array}$ & $\begin{array}{l}\text { Statements } \\
\text { invoking, } \\
\text { suggesting, or } \\
\text { mentioning } \\
\text { ownership of } \\
\text { land by local } \\
\text { communities } \\
\text { based on } \\
\text { ancestral past. }\end{array}$ & $\begin{array}{l}\text { Words, } \\
\text { phrases, } \\
\text { sentences } \\
\text { mentioning, } \\
\text { suggesting, or } \\
\text { invoking land } \\
\text { ownership by } \\
\text { local } \\
\text { communities } \\
\text { based on } \\
\text { ancestral past. }\end{array}$ & $\begin{array}{l}\text { Words, } \\
\text { phrases, } \\
\text { sentences that } \\
\text { do not } \\
\text { mention, } \\
\text { suggest or } \\
\text { invoke } \\
\text { ownership of } \\
\text { land by local } \\
\text { communities }\end{array}$ & $\begin{array}{l}\text { I knew I was } \\
\text { going to } \\
\text { develop this } \\
\text { place } \\
\text { [farmland] to } \\
\text { earn my living } \\
\text { and when I die, } \\
\text { my children } \\
\text { would remain } \\
\text { there. }\end{array}$ \\
\hline
\end{tabular}




\begin{tabular}{|c|c|c|c|c|}
\hline & & & $\begin{array}{l}\text { based on } \\
\text { ancestral past. }\end{array}$ & $\begin{array}{l}\text { "all lands } \\
\text { presently } \\
\text { owned and } \\
\text { occupied by } \\
\text { the Batanga" } \\
\text { "we find this } \\
\text { current move } \\
\text { to deforest our } \\
\text { lands" } \\
\text { "grabbing } \\
\text { communal } \\
\text { land" }\end{array}$ \\
\hline Negotiation & $\begin{array}{l}\text { Statements } \\
\text { suggesting, } \\
\text { mentioning, } \\
\text { invoking the } \\
\text { lack of, or } \\
\text { absence of } \\
\text { talks with local } \\
\text { communities } \\
\text { on project } \\
\text { sites. }\end{array}$ & $\begin{array}{l}\text { Words, } \\
\text { phrases, } \\
\text { sentences } \\
\text { mentioning, } \\
\text { invoking, or } \\
\text { suggesting the } \\
\text { lack of, or } \\
\text { absence of } \\
\text { talks with local } \\
\text { communities } \\
\text { on project } \\
\text { sites. }\end{array}$ & $\begin{array}{l}\text { Words, } \\
\text { phrases, } \\
\text { sentences that } \\
\text { do not } \\
\text { mention, } \\
\text { invoke or } \\
\text { suggest the } \\
\text { lack of, or } \\
\text { absence of } \\
\text { talks with local } \\
\text { communities } \\
\text { on project } \\
\text { sites. }\end{array}$ & $\begin{array}{l}\text { "One day, I } \\
\text { came to my } \\
\text { farm and I } \\
\text { found that they } \\
\text { had bulldozed } \\
\text { everything" } \\
\text { "without local } \\
\text { communities' } \\
\text { knowledge" } \\
\text { "informed } \\
\text { consent of } \\
\text { local } \\
\text { communities } \\
\text { was not sought } \\
\text { at all" }\end{array}$ \\
\hline
\end{tabular}




\begin{tabular}{|c|c|c|c|c|}
\hline & & & & $\begin{array}{l}\text { "developing } \\
\text { land without } \\
\text { the consent of } \\
\text { the } \\
\text { communities } \\
\text { that surround } \\
\text { and depend on } \\
\text { it" }\end{array}$ \\
\hline $\begin{array}{l}\text { Loss of } \\
\text { livelihood }\end{array}$ & $\begin{array}{l}\text { Statements } \\
\text { suggesting, } \\
\text { mentioning, or } \\
\text { invoking the } \\
\text { loss of } \\
\text { livelihood } \\
\text { because of the } \\
\text { project. }\end{array}$ & $\begin{array}{l}\text { Words, } \\
\text { phrases, or } \\
\text { sentences } \\
\text { suggesting, } \\
\text { mentioning, or } \\
\text { invoking the } \\
\text { loss of } \\
\text { livelihood } \\
\text { because of the } \\
\text { project. }\end{array}$ & $\begin{array}{l}\text { Words, } \\
\text { phrases, or } \\
\text { sentences that } \\
\text { do not suggest, } \\
\text { mention, or } \\
\text { invoke the loss } \\
\text { of livelihood } \\
\text { because of the } \\
\text { project. }\end{array}$ & $\begin{array}{l}\text { "the } \\
\text { destruction of } \\
\text { livelihoods for } \\
\text { thousands of } \\
\text { Cameroonians" } \\
\text { "traditional } \\
\text { livelihood } \\
\text { activities inside } \\
\text { the } \\
\text { Concession" }\end{array}$ \\
\hline $\begin{array}{l}\text { Environmental } \\
\text { damage }\end{array}$ & $\begin{array}{l}\text { Statements } \\
\text { suggesting, } \\
\text { mentioning, or } \\
\text { invoking } \\
\text { environmental } \\
\text { degradation as } \\
\text { a consequence } \\
\text { of the project. }\end{array}$ & $\begin{array}{l}\text { Words, } \\
\text { phrases, } \\
\text { sentences } \\
\text { suggesting, } \\
\text { mentioning, or } \\
\text { invoking } \\
\text { environmental } \\
\text { degradation as } \\
\text { a consequence } \\
\text { of the project. }\end{array}$ & $\begin{array}{l}\text { Words, } \\
\text { phrases, } \\
\text { sentences not } \\
\text { suggesting, } \\
\text { mentioning, or } \\
\text { invoking } \\
\text { environmental } \\
\text { degradation as } \\
\text { a consequence } \\
\text { of the project. }\end{array}$ & $\begin{array}{l}\text { "the proposed } \\
\text { plantation is } \\
\text { located } \\
\text { between five } \\
\text { protected areas } \\
\text { and any } \\
\text { attempt to open } \\
\text { it up will have } \\
\text { catastrophic } \\
\text { effects on the } \\
\text { environment" } \\
\text { "contrary to the } \\
\text { preservation of } \\
\text { the biosphere" }\end{array}$ \\
\hline & & & & $\begin{array}{l}\text { "irreversible } \\
\text { environmental } \\
\text { impact" }\end{array}$ \\
\hline
\end{tabular}




\begin{tabular}{|c|c|c|c|c|}
\hline & & & & $\begin{array}{l}\text { "an important } \\
\text { area for high } \\
\text { biodiversity" }\end{array}$ \\
\hline \multirow[t]{3}{*}{$\begin{array}{l}\text { Community } \\
\text { Leadership }\end{array}$} & $\begin{array}{l}\text { Statements } \\
\text { suggesting, } \\
\text { mentioning, or } \\
\text { invoking the } \\
\text { sidelining of } \\
\text { communities in } \\
\text { favor of titular } \\
\text { leaders. }\end{array}$ & $\begin{array}{l}\text { Words, } \\
\text { phrases, } \\
\text { sentences } \\
\text { suggesting, } \\
\text { mentioning, or } \\
\text { invoking the } \\
\text { sidelining of } \\
\text { communities in } \\
\text { favor of titular } \\
\text { leaders. }\end{array}$ & $\begin{array}{l}\text { Words, } \\
\text { phrases, } \\
\text { sentences not } \\
\text { suggesting, } \\
\text { mentioning, or } \\
\text { invoking the } \\
\text { sidelining of } \\
\text { communities in } \\
\text { favor of titular } \\
\text { leaders. }\end{array}$ & $\begin{array}{l}\text { "land } \\
\text { negotiations } \\
\text { were done... } \\
\text { targeting the } \\
\text { chiefs and } \\
\text { some few } \\
\text { influential } \\
\text { decision- } \\
\text { making } \\
\text { members of the } \\
\text { communities" }\end{array}$ \\
\hline & & & & $\begin{array}{l}\text { "promise of } \\
\text { future benefits } \\
\text { to certain } \\
\text { individuals" }\end{array}$ \\
\hline & & & & $\begin{array}{l}\text { "obtain local } \\
\text { authorities' } \\
\text { favor" }\end{array}$ \\
\hline
\end{tabular}

Table 4. Benoit's (1997) Five Typologies Applied in Cases

\begin{tabular}{|l|l|l|l|l|}
\hline Strategy & $\begin{array}{l}\text { Conceptual } \\
\text { Definition }\end{array}$ & $\begin{array}{l}\text { Operational } \\
\text { Definition }\end{array}$ & $\begin{array}{l}\text { Example of } \\
\text { what is } \\
\text { included from } \\
\text { cases }\end{array}$ & $\begin{array}{l}\text { Example of } \\
\text { what is not } \\
\text { included }\end{array}$ \\
\hline $\begin{array}{l}\text { Denial (simple } \\
\text { denial, shift the } \\
\text { blame) }\end{array}$ & $\begin{array}{l}\text { The accused } \\
\text { may simply } \\
\text { deny did not } \\
\text { perform act; } \\
\text { act performed } \\
\text { by another. }\end{array}$ & $\begin{array}{l}\text { Word, phrase, } \\
\text { or sentence } \\
\text { that alluded or } \\
\text { directly } \\
\text { referred to } \\
\text { denial } \\
\text { discussed in }\end{array}$ & $\begin{array}{l}\text { "It totally } \\
\text { unjustified to } \\
\text { suggest that } \\
\text { Shell, by virtue } \\
\text { of endeavoring } \\
\text { to carry out its } \\
\text { legitimate }\end{array}$ & $\begin{array}{l}\text { Word, phrase, } \\
\text { or sentence that } \\
\text { does not allude } \\
\text { to or directly } \\
\text { refer to denial. }\end{array}$ \\
\hline
\end{tabular}




\begin{tabular}{|c|c|c|c|c|}
\hline & & $\begin{array}{l}\text { the conceptual } \\
\text { explication of } \\
\text { the category. }\end{array}$ & $\begin{array}{l}\text { business of oil } \\
\text { exploration is } \\
\text { in some way } \\
\text { responsible for } \\
\text { such conflict or } \\
\text { the level of the } \\
\text { Nigerian } \\
\text { government's } \\
\text { response to } \\
\text { them ... } \\
\text { private } \\
\text { companies } \\
\text { have neither the } \\
\text { right nor the } \\
\text { competence to } \\
\text { become } \\
\text { involved" }\end{array}$ & \\
\hline $\begin{array}{l}\text { Evasion of } \\
\text { responsibility } \\
\text { (provocation, } \\
\text { defeasibility, } \\
\text { accident, good } \\
\text { intentions) }\end{array}$ & $\begin{array}{l}\text { Act was in } \\
\text { response to act } \\
\text { of another; } \\
\text { lack of } \\
\text { information } \\
\text { ability to take } \\
\text { action; Act was } \\
\text { a mishap; } \\
\text { meant well in } \\
\text { act. }\end{array}$ & $\begin{array}{l}\text { Word, phrase, } \\
\text { or sentence } \\
\text { that alluded or } \\
\text { directly } \\
\text { referred to } \\
\text { components of } \\
\text { the strategy of } \\
\text { Evasion of } \\
\text { responsibility }\end{array}$ & $\begin{array}{l}\text { "Inspired by a } \\
\text { desire to 'do } \\
\text { something' for } \\
\text { Africa after a } \\
\text { visit to war- } \\
\text { torn West } \\
\text { Africa in 1999, } \\
\text { our CEO, } \\
\text { Bruce Wrobel, } \\
\text { quit his job to } \\
\text { start Herakles } \\
\text { Capital with a } \\
\text { commitment to } \\
\text { using his skills } \\
\text { in large-scale } \\
\text { project } \\
\text { development } \\
\text { for the benefit } \\
\text { of sustainable } \\
\text { economic } \\
\text { development in } \\
\text { Africa" }\end{array}$ & $\begin{array}{l}\text { Word, phrase, } \\
\text { or sentence that } \\
\text { does not allude } \\
\text { to or directly } \\
\text { refer to } \\
\text { components of } \\
\text { the strategy of } \\
\text { Evasion of } \\
\text { Responsibility. }\end{array}$ \\
\hline $\begin{array}{l}\text { Reducing } \\
\text { Offensiveness } \\
\text { of Event } \\
\text { (bolstering, }\end{array}$ & $\begin{array}{l}\text { Stress good } \\
\text { traits; act not } \\
\text { serious, act } \\
\text { less offensive, }\end{array}$ & $\begin{array}{l}\text { Word, phrase, } \\
\text { or sentence } \\
\text { that alluded or } \\
\text { directly }\end{array}$ & $\begin{array}{l}\text { Herakles } \\
\text { officials told } \\
\text { investors "the } \\
\text { Cameroon }\end{array}$ & $\begin{array}{l}\text { Word, phrase, } \\
\text { or sentence that } \\
\text { does not allude } \\
\text { to or directly }\end{array}$ \\
\hline
\end{tabular}




\begin{tabular}{|c|c|c|c|c|}
\hline $\begin{array}{l}\text { minimization, } \\
\text { differentiation, } \\
\text { transcendence, } \\
\text { attack accuser, } \\
\text { compensation) }\end{array}$ & $\begin{array}{l}\text { act is placed in } \\
\text { a broader } \\
\text { context, reduce } \\
\text { credibility of } \\
\text { accuser, } \\
\text { reimburse } \\
\text { victim }\end{array}$ & $\begin{array}{l}\text { referred to } \\
\text { components of } \\
\text { the strategy of } \\
\text { Evasion of } \\
\text { responsibility }\end{array}$ & $\begin{array}{l}\text { Plantation } \\
\text { providing an } \\
\text { economically } \\
\text { underdeveloped } \\
\text { region of } \\
\text { Cameroon with } \\
\text { decades of } \\
\text { large scale } \\
\text { employment } \\
\text { and needed } \\
\text { infrastructure } \\
\text { including } \\
\text { roads, schools } \\
\text { and hospitals" }\end{array}$ & $\begin{array}{l}\text { refer to } \\
\text { components of } \\
\text { the strategy of } \\
\text { Reducing } \\
\text { Offensive of } \\
\text { Event }\end{array}$ \\
\hline $\begin{array}{l}\text { Corrective } \\
\text { Action }\end{array}$ & $\begin{array}{l}\text { Plan to solve } \\
\text { or prevent } \\
\text { problem }\end{array}$ & $\begin{array}{l}\text { Word, phrase, } \\
\text { or sentence } \\
\text { that alluded or } \\
\text { directly } \\
\text { referred to } \\
\text { components of } \\
\text { the strategy of } \\
\text { Corrective } \\
\text { Action. }\end{array}$ & $\begin{array}{l}\text { Herakles } \\
\text { officials said } \\
\text { "environmental } \\
\text { considerations } \\
\text { are now given } \\
\text { due attention to } \\
\text { right the } \\
\text { wrongs of the } \\
\text { past" }\end{array}$ & $\begin{array}{l}\text { Word, phrase, } \\
\text { or sentence that } \\
\text { does not allude } \\
\text { to or directly } \\
\text { refer to } \\
\text { components of } \\
\text { the strategy of } \\
\text { Corrective } \\
\text { Action }\end{array}$ \\
\hline Mortification & $\begin{array}{l}\text { Apologize for } \\
\text { act }\end{array}$ & $\begin{array}{l}\text { Word, phrase, } \\
\text { or sentence } \\
\text { that alluded or } \\
\text { directly } \\
\text { referred to } \\
\text { components of } \\
\text { the strategy of } \\
\text { Mortification }\end{array}$ & & $\begin{array}{l}\text { Word, phrase, } \\
\text { or sentence that } \\
\text { does not allude } \\
\text { to or directly } \\
\text { refer to } \\
\text { components of } \\
\text { the strategy of } \\
\text { Mortification }\end{array}$ \\
\hline
\end{tabular}

Note: while there was no direct apology from either of two companies analyzed, the notion of "revamped impetus" mentioned by Herakles Officials explaining the renewal approach they took in the second phase of the crisis could be seen as alluding to an apology. The same applies to Shell in which they described their new approach to the crisis as a result of the mistakes of the past. 


\section{Summary}

This chapter is a description of my methods in data collection, coding procedure, and thematic analysis. Conceptual and operational definitions of the categories are explained as well as the frames of analysis in this research.

In the following two chapters, I analyze two cases of transnational crisis rhetoric in African contexts using the model of communication. My effort is to inductively identify communicative dynamics and contexts that challenge the assumptions of these models in order to modify the renewal model as appropriate. In doing so, I intend to add to the current model and to contribute to the development of a more culturally grounded understanding of multinational crisis communication in Nigeria and Cameroon. 


\section{Case 1: Royal Dutch Oil Crisis in Nigeria}

\subsection{Introduction}

This chapter is an analysis of the Shell oil crisis in the Niger Delta region of Nigeria. To better situate the crisis within the context of the current research, the characteristics of Niger Delta are discussed by looking at the history, governance, and economic and social relations in the region. The chapter also provides a background for Shell's operations and its community relations in the Niger Delta. The overarching purpose is to understand Shell's corporate rhetoric in response by critically analyzing the points of conflict in this crisis set within contextual complexities and exigencies, situational contradictions, and tenacious histories. The chapter develops an assessment of lessons learned from the company's crisis communication response and a discussion of what these lessons mean for organizational crisis rhetoric and communication practices keeping in mind the political dynamics of postcolonial representation.

\subsection{Niger Delta Region}

The Niger Delta is located in Southern Nigeria and shares its eastern boundary with Cameroon (Niger Delta Development Commission (NDCC), "Master Plan,” 2007). The region has an estimated population of 32 million - that is, 22 percent of Nigeria's total population (Francis, Lain \& Rossiasco, 2011). The region covers 112,110 square kilometers or 43,286 square miles (NDDC, "Master Plan," 2007). According to the Ministry of Niger Delta Affairs (MNDA) and Niger Delta Development Commission (NDDC), there are 40 ethnic groups speaking some 250 languages and/or dialects (also 
see United Nations Development Program (UNDP) "Human Development Report," 2006). Agriculture and fishing constitute 48 percent of primary occupations and sources of livelihood (Francis et al., 2011).

The region's colonial experience effectively began when the area was established as a protectorate under British rule (Wikipedia, "Niger Delta"). In 1885 the region was known as British Oil Rivers Protectorate until 1893 when it was expanded into the Niger Coast Protectorate (Wikipedia, "Niger Delta"). In 1951, Niger Delta became part of the Eastern Region of Nigeria - one of three and later four regions of the country.

Nigeria is the largest oil producing nation in Africa and the world's fourth largest crude oil exporter (United States Energy Information Administration, 2016) thanks to the oil rich Niger Delta. The Niger Delta region originally comprised three states, namely, Bayelsa, Delta, and Rivers (Alagoa, 2004). However, the region was expanded to include all nine of the petroleum oil and gas producing states (Nigeria has 36 states). The nine states include Abia, Akwa Ibom, Bayelsa, Cross Rivers, Delta, Edo, Imo, Ondo, and Rivers. Several reasons explain this expansion. Some scholars dispute the current geography of the Niger Delta on the grounds that what currently constitutes the region is based on political mapping and not the historical location of the region (see UNDP, 2006; Ibaba, 2005). The United Nations Development Program (UNDP) in its 2006 "Niger Delta Development Report" suggested the Nigerian government's decision to include all nine oil and gas producing states in the Niger Delta Region was for "administrative convenience," "political expedience," and "development objectives" (p. 19). Shell Petroleum Development Company is the largest oil company in Nigeria, alongside the 
Nigerian National Petroleum Company, Chevron/Texaco, Exxon Mobil, Total Fina, ELF Aquitaine, and Agip (see Orogun, 2010).

\subsection{The Niger Delta Question}

Enshrined in the history of the Niger Delta is what scholars refer to as "the Niger Delta question" (see Orugon, 2010). This question revolves around issues of ownership of oil resources in the region and asks why the Niger Delta region is so rich in oil yet communities live in abject poverty (Orugon, 2010; Alagoa, 2004). Control over oil resources has been a major point of contention in the region. Orugon (2010) explains the Niger Delta question as pointing to communities' "claims of landownership as well as mineral resources within their delineated territorial boundaries" (p. 466). The question also entails the impact of oil production activities in the region including environmental problems caused by oil spills and gas flaring (Orugon, 2010). The Niger Delta question must be understood as well through the perspectives of some militant groups in region.

Militant groups, including the most prominent militia - Movement for the Emancipation of the Niger Delta (MEND) - charge "internal colonialism," "political marginalization," and environmental neglect by both the oil companies and the host government (Orogun, 2010). The deplorable situation in the Niger Delta is also captured in a UNDP (2006) report which noted that the region is "suffering from administrative neglect, crumbling social infrastructure and services, high unemployment, social deprivation, abject poverty, filth and squalor, and endemic conflict" (p. 9). Several marginalized ethnic groups in the Niger Delta, particularly the Ogoni, Ijaw, Urhobo and 
Itsekiri, contest the role of multinational oil corporations in the region. Community protests that have turned into deadly riots evidence the ongoing unrest in this region.

The Niger Delta question has haunted the Nigerian government and transnational oil corporations operating in the region. Since the 1990s, the region has been engulfed in unending violence resulting to the militarization of nearly the entire region by ethnic militia groups and Nigerian military and police forces (Koos \& Jan, 2015). Elite and local politicians often fund competing militia groups to advance their economic and political agendas including gaining access to oil and gas resources in the region. The government of Nigeria regularly launches huge military crackdowns on militant groups as was the case in 2008 and 2009 and the MEND militant group has been a major target for government forces in the Niger Delta region (Fatade, 2009). The violence in this region has led to thousands of people fleeing their villages while hundreds are reported dead (Walker, 2009; IRIN Africa, 2009). The government of Nigeria has offered amnesty to members of militant groups and in return, the militants are required to surrender their weapons and undergo vocational training and rehabilitation sponsored by the Nigerian government (BBC News, 2011). However, this has not completely deterred militant violence in the region. The ongoing militant violence in the Niger Delta has been blamed on marginalization of the region by the Nigerian government as well as on oil operation activities of multinational corporations' oil exploitation and relations with local communities (see Orugon, 2010).

Oil companies are in the midst of the violence. Foreign oil workers including sailors are regularly kidnaped and held by militant groups for ransom. A regular target for 
militants has been pipelines operated by multinational oil companies with Shell as the largest foreign oil company operating in Nigeria being the most affected. In 2016, Shell Petroleum company was a major target when militants launched a heavy attack on pipelines run by the multinational. Oil production in Nigeria was reported to be down 300,000 barrels a day following a huge explosion on the pipelines (Uguru \& Faul, 2016). It was also in 2016 that a new militant group, the Niger Delta Avengers, announced its creation (BBC News, 2016). This militant group attacked several pipelines and oil facilities in the region; the attack resulted in a 20 -year record low oil production for Nigeria, dropping the country to the second largest oil producer in Africa after Angola. The significance is that Nigeria has always been the largest oil producing country in Africa and has frequently been ranked fourth largest producer of oil in the world (Holodny, 2016; The Economist, 2016).

\subsubsection{Governance}

Nigeria has three-tier administrative structure: federal, state, and local. The federal government level holds "exclusive powers" but sustains "concurrent powers" with state governments (NDDC “Master Plan,” 2005, p. 52). At the same time, the state and local government levels exercise "residual power" (NDDC "Master Plan,” 2007, p. 52). This means that the federal government has the power to veto certain state government decisions, and the same applies to the relationship between the state and local governments. Key actors in the affairs of this region can be broadly described as local communities, community leaders, local, state and federal offices and agencies, and multinational oil corporations. The United Nations Development Program in a 2006 study 
conducted in the Niger Delta pointed to prevailing "inequalities in the allocation of resources from oil and gas" (p. 19) and a heavy top-down administrative approach to management in the country noting that "transparency," "accountability," and "integrity" continue to elude governance in the region (p. 5). Scholars have argued that governance in the Niger Delta is strongly influenced by multinational oil companies, who are perceived as influencing policies and development programs in the region (Orugon, 2010; also see Alagoa, 2004). Given the overlap between the host government's authority and the power of the oil companies operating in the Niger Delta, inhabitants and scholars alike blame protests, killings, widening gaps of economic inequalities, and environmental problems plaguing the region, on both the government and the multinational oil companies (see Ojefia, 2004).

\subsubsection{Economic and Social relations}

Turning to the local level, history and communality play a role in governance and decision-making. As Alagoa (2004) observes, in the Niger Delta "[ $\mathrm{t}]$ he past is ... manifestly a part of the present" (p. 63) as present actions or conduct are contextualized within communities' history (Alagoa, 2004). In fact, Alagoa argued that conflicts occur in the region when "history" is not considered by parties involved. He pointed out that "policymaking...has proved ineffective to contain the enormous problems of the Niger

Delta region...in part, the result of disagreements over historical interpretation within communities, and the lack of a historical perspective or neglect of the historical factor by government and oil corporations" (p. 64). 
The economic and social relations among the local people of Niger Delta are generally described as "symbiotic" (Usuanlele, 2007, p. 484; also see Lloyd, 2007). Tracing the nature of these relations among ethnic groups, Usuanlele (2007) and Lloyd (2007) point to both group and communal structures as mutually beneficial to the people. Communities continue to sustain a group decision-making process and communal structures of power alongside government administration (see Amodu, 2013). These communal structures include several decision-making bodies and participation by families, women, and youth. A chief or traditional ruler along with a Council of Elders heads local communities. The Council of Elders whose members are from families constituting the community (Amodu, 2013) handles disputes at all levels of the community. A Trustee Board usually serves as the body that implements decisions (Amodu, 2013).

The struggle over who owns land and oil resources continues to deepen the antagonisms that characterize the economic and social relations in the area. Orugon (2010) noted that, "The issues of land ownership and proprietorship of crude oil resource endowment have pitched the Nigerian federal government and the transnational oil corporations against the feuding ethno-communities of the Niger Delta" (p. 469). These issues and conflicts are strongly enshrined in articulations of the Niger Delta question.

Another aspect characterizing economic and social relations in the region is social exclusion. The Niger Delta is the poorest oil-producing region in the world despite being the fourth largest exporter of crude oil (see US Energy Information Administration, 2016). For decades, communities in this region have felt neglected in the development 
process in Nigeria, while some groups within the region have further been marginalized (See UNDP “Human Development Report," 2006; NDDC "Master Plan,” 2007). A case often pointed to is the Ogoni people whose leader, Ken Saro-Wiwa, was executed by hanging in 1995 for confronting the government and oil companies over exploiting oil but doing very little for the economic and social development of Ogoniland. I will say more about this case shortly.

\subsection{Shell in Nigeria}

Shell is a global group of energy and petrochemicals companies with about 93,000 employees in more than 90 countries and territories ("Shell Nigeria"). The Royal Dutch Shell Group first established an oil venture with BP Plc in Nigeria in 1936 and two years later, the company was issued an exploration license to prospect for oil throughout Nigeria under the name Shell D'Arcy (“Shell in Nigeria”). The company first drilled an oil well in Nigeria in January 1956; that same year, the company name was changed to Shell-BP Petroleum Development Company of Nigeria Limited. The first export of oil from Nigeria by the company was in February 1958 (Shell Nigeria, "Our history"). In 1979, Shell Petroleum Development Company of Nigeria (SPDC) was created incorporating assets of the older Shell-BP consortium (Reuters, "Timeline Shell in Nigeria," 2013).

Shell Petroleum Development Company produces 39 percent of the total oil in Nigeria. Operations are in the shallow water and onshore in Niger Delta ("Shell Interests in Nigeria," 2012). The company holds a land lease contract of operation for an area of 
30,000 square kilometers and has a network of more than $9,000 \mathrm{~km}$ of flowlines and pipelines, 71 producing oil fields, nearly 1,000 oil producing wells, 87 flow stations, nine gas plants and two big oil terminals for export ("Shell Interests in Nigeria," 2012). SPDC's average production is over one million barrels of oil per day ("Shell Interests in Nigeria," 2012).

\subsection{The Crisis}

Shell's operations and community relations in the Niger Delta region have been disrupted by protests in many communities. Shell has been accused by communities of environmental degradation including heavy pollution, poisoning of fishing grounds, and destruction of farmlands by frequent oil spills and gas flaring. In addition, accusations of exploitation, human rights abuse, corruption, and killings continue to trouble Shell in the Niger Delta. This crisis can be understood by looking at the issues raised by local communities and other stakeholders regarding Shell's operations. Specifically, the following discussion addresses oil spills and gas flaring from Shell's operations in the region; the protests plaguing Shell's operations in Niger Delta communities; and the lawsuits against Shell.

\subsubsection{Oil Spills and Gas Flaring}

According to company documents, oil spills occur year-round. Between 2011 and 2016, there have been spills every month with the monthly average just over 11 spills a month in 2014 ("Shell Oil Spill Data"). A study published in 2010 by the Ecumenical Council for Corporate Responsibility (ECCR) describes what it refers to as "systemic 
problems" (p. 44) as the major causes of oil spills including aging pipelines and delayed spill response. Specifically, the study blames Shell for allowing oil to flow through 40year old pipelines. The study also pointed to delayed oil spill response by Shell, noting that oil spill inspection can take 24 hours to several days, weeks or even months, allowing much of the spill to disperse into widespread pollution and making the reported spilled amount seem smaller than what has actually been lost (p. 42). In addition, Shell contractors are accused of using topsoil transported from other localities to "mask contaminated sites" (ECCR “Three Challenges Facing Shell,” 2010). The ECCR study estimates that yearly oil spills in the Niger Delta region compare to the Exxon Valdese oil spill disaster. A United Nations Report (2011) estimated that it would take three decades to clean up oil spills in the Niger Delta at the cost of US \$1billion (also see Mark, 2011). An Amnesty International (2015) report accused Shell of making "false claims" (para 3) about cleaning spills in the region. The report pointed to the impact of the spills: "By inadequately cleaning up the pollution from its pipelines and wells, Shell is leaving thousands of women, men and children exposed to contaminated land, water and air, in some cases for years or even decades" (Amnesty International, 2015, para 3).

A 1993 newspaper report painted the picture of oil spills in the Niger Delta by quoting a resident of one of the communities in the region who watched for weeks as a "fine spray of petroleum coated the bamboo and palm trees around the Sasiga rivulet until, mixed with acid rain and humid air, it gave the plants the milky brown sheen of a chocolate forest" (McGreal, 1993, p. A8; also see Amanze-Nwachuku, 2011). The news 
report indicates that this was the result of a burst pipe from Shell's pumping station at Korokoro, another community in the region.

Strong demands for cleaning up spills, a share of oil profits, and a fairer compensation for land are at the center of the crisis pitting communities against Shell. In 1995, just months before his execution, Ken Saro-Wiwa, the leader of the Movement for the Survival of the Ogoni People (MOSOP), summed up the situation of the oil spills in Ogoniland: "Plants are now dying, land is flooded, fish are killed ... our lives are becoming unbearable ... we have scratches on our body and rashes on our skin any time we go into the water" (Vidal, 1995, p. T2). Shell pulled out of its Ogoni ground operations in 1993, although its network of oil pipelines still run through Ogoniland.

Gas flaring is another important aspect in this crisis. The Nigerian National Petroleum Company has reported that major oil companies in the country flared 23.5 billion cubic feet of gas in January of 2012 (see Reuter, 2012). Shell has been accused of this practice. In the Niger Delta, a fisherman recounted the gas flaring ordeal: "Because of the flares it is so hot, it is smoky, the air is thick and it is constantly daytime here" (Mark, 2012, p. 7). The fisherman further stated: "Our rivers are black and the [acid] rain eats our houses. Our bodies are covered in oil. You feel that if you live to old age here, it is a miracle" (Mark, 2012, p. 7). The World Bank (as cited in the press release by Friends of the Earth) pointed out that flaring in Nigeria contributes more greenhouse gas emissions than all other sources in sub-Saharan Africa combined. The press release from Friends of the Earth also states that "the cocktail of toxic substances which has been 
emitted in the flares for over 40 years, including benzene and particulates, has exposed Niger Delta communities to severe health risks and property damage" (para 3).

\subsubsection{Protests against Shell}

Anger against Shell in the Niger Delta is endemic as communities have struggled to cope with severe oil spills and gas flaring causing widespread pollution and other forms of environmental degradation including contamination of fishing grounds, farmlands, and destruction of the ecosystem (mangroves and forest products as well as animals). Additional infrastructure issues such as lack of social amenities (including water and electricity), roads, and overall underdevelopment are choking the Niger Delta communities. There is also anger over the failure to fairly distribute oil royalties. These layered complaints have for decades generated negative perceptions and little confidence in Shell among local peoples, plaguing Shell's operations (see Orugon, 2010).

Specific protests tell the story of Shell's exploitation in the Niger Delta. In 1990, the Etche people in the Niger Delta protested against Shell. Jonathan Steele of the London-based newspaper, The Guardian, described the protest as "peaceful" but noted that "Shell's response was to call for police in case of further action" (p. 3). The outcome was the massacre of 80 people and 495 homes destroyed (p. 3). According to the report, local communities "held Shell accountable" for choosing to invite the police rather than "negotiating" (Steele, 1995, p. 3). As protests spread against Shell, in the summer of 1992, the Mobile Police Force (MPF) was sent to quell a protest in the Gbaran oilfield where 30 people were reported shot and 150 others beaten (Steele, 1995). 
However, it was not until January 4, 1993, that Shell faced the largest protests in its history of operations in the Niger Delta. Three hundred thousand Nigerians from Ogoni communities held a mass protest (Reuters, "Timeline Shell in Nigeria," 2013; University of Maryland "Minorities at Risk," 2016). The MPF is reported to have killed 2,000 Ogoni people, burnt down 27 villages and forced 80, 000 out of their homes (Steele, 1995, p. 3). April 30, 1993, saw another protest against Shell by 10,000 Ogoni people. The protests came following the destruction of a newly planted farmland by construction work on a Shell pipeline. Soldiers are reported to have opened fire on protesters leaving at least 10 wounded (University of Maryland "Minority at Risk," 2016). The leader of the Movement for the Survival of the Ogoni People (MOSOP) was Ken Saro-Wiwa, who led protest movements first against Shell, then against the Nigerian Government for the neglect of the oil-rich region. These protests brought considerable national and international attention to the underdevelopment plaguing the people of Ogoni and the Niger Delta in general. Together with eight other Ogoni people, SaroWiwa was sentenced to death by hanging on November 10, 1995. This provoked anger and condemnation against Shell as communities accused the company of condoning the executions. Jonathan Steele (1995) pointed out that Ken Saro-Wiwa was paying the price for daring to "take action against the rape of their land, which left their soil and water polluted and gave them nothing except a legacy of rusting pipelines, thousands of unsightly wells and refineries, and no material benefits from the oil profits at all” (p. 3). The Movement for the Survival of the Ogoni people (MOSOP) vowed to continue protesting any resumption of oil production in Ogoniland (Amanze-Nwachuku, 2011). 
As in earlier protests, Durban protesters accused the oil company of "summary execution, crimes against humanity, torture, inhumane treatment as well as arbitrary arrest and detention" (Umar, 2009, para 1). In June 2016, Shell's pipelines in Forcados, a local community in the Niger Delta, were attacked (BBC Monitoring Africa, June 4, 2016). Clearly, Shell's crisis in the Niger Delta is prolonged and ongoing.

\subsubsection{Lawsuits against Shell}

NGO reports suggest the weak and corrupt judicial and legal system in Nigeria has been unable to adequately hold Shell accountable, hence, cases against Shell are tried in international courts (see Amnesty International, 2017). Shell was sued in a United States federal court in Manhattan by relatives of the nine Ogoni activists executed in 1995 (see ccrjustice.org). The lawsuit was filed on November 8, 1996, by the Center for Constitutional Rights (CCR) and co-counsel EarthRight International on behalf of the plaintiffs (ccrjustice.org). A statement on ccrjustice.org indicates that Shell was accused of complicity in human rights abuses against the Ogoni people in the Niger Delta, including summary executions, crimes against humanity, torture, inhumane treatment, arbitrary arrests, wrongful death, assault and battery, and infliction of emotional distress (CCR “Wiwa et al v. Royal Dutch Petroleum et al.," para 2; see Business Day, June 19, 2009). On June 8, 2009, the eve of the hearing, all parties in the case agreed to a settlement for all three lawsuits. Shell agreed "to compensate the injuries and the deaths of their family members, and also create a trust for the benefit of the Ogoni, as well as pay [some of] the costs of litigations" (Business Day, June 19, 2009, para 1). According 
to the Center for Constitutional Rights, the settlement provided a total of US \$15.5 million to be paid by Shell (ccrjustice.org).

In recent years, Shell has had to face several other lawsuits over its operations in the Niger Delta in European nations' courts. In January 2015, the company agreed to settlement in a case in the UK by paying $£ 55$ million as compensation to the Niger Delta community of Bodo for oil spills and other environmental damage (Alike, 2015). The company, on December 18, 2015, was scheduled for a hearing in a Dutch Court of Appeal for "its failure to stop and clean up decades of oil pollution" in the Niger Delta (Alike, 2015, para 1). According to Amnesty International (as cited in Alike, 2015), the case is a renewed attempt by the communities of Niger Delta "to hold Shell to account" (para 2) for its operations in the region.

\subsection{Shell's crisis communication and management approach}

Between 1993 and mid-2000s, Shell's response to the crisis haunting its operations in the Niger Delta very much contrasted with the approach it effectively engaged with between 2006 and 2016. Shell refers to its response to the crisis in the 1990s to mid-2000s as "old" or the "previous" approach. The "new approach" for the company's crisis response was effectively implemented starting in 2006. This company identified distinction aligns with my distinction between the apologia models of corporate crisis rhetoric and the alternative renewal model, as I explain below. 


\subsubsection{Old Approach to Crisis (1993-mid-2000s)}

Shell has described its old approach to events in the Niger Delta as top-down, which they now argue, was inefficient. Shell claims in the old approach, the company assumed "direct responsibility for development" in the Niger Delta region; and that there was "limited capacity building" for local communities ("Global Memorandum of Understanding," 2006). The company also noted that in the old approach, communities were "relegated to passive a role" ("Global Memorandum of Understanding," 2006). This, according to Shell, resulted in "lack of trust" and "transparency" in their relations with local communities.

This old approach was predominantly defensive (apologia) rhetoric (see, Benoit, 1995, 1997; Coombs, 2007; also see chapter 2 of this dissertation). Denial was the principal strategy Shell used in public communication. Other strategies vividly applied were scapegoating (blame) and attack the accuser. There were also several attempts to position the company as a victim (see Coombs, 2007). It is worthy of note that these crisis communication strategies were enacted by Shell leaders and spokespersons. The following paragraphs present evidence of defensive (reactive) strategies. When coding data to analyze Shell's early communication, Apologia typologies (see Benoit, 1995, 1997) were frames of analysis. The unit of analysis was direct statements from company leaders and spokespersons about the crisis. These strategies were identified by applying the coding procedure described in chapter 3.

In 1995, the communities in the Niger Delta repeatedly accused Shell of conniving with the Nigerian military (by paying them) to quell protests against its 
operations during which many deaths were often reported (see Viddal, 1995). Shell officials "denied completely" the company's involvement in the unrest in Ogoni, describing the accusations as "distorted and inaccurate" and blaming protestors' deaths on ethnic conflict between communities and disputes over territory (Vidal, 1995, p. T2). Responding to accusations of exploitation (which the people said had increased poverty) and the lack of social amenities such as water, electricity, and roads in the Niger Delta, Shell officials pointed to the Nigerian federal government as being responsible for development and wealth-sharing (Vidal, 1995, p. T2).

Denial and scapegoating are two strategies used in this instance by Shell officials. Shell International spokesperson, David Williams, used denial and attempts to scapegoat in his response: "It is totally unjustified to suggest that Shell, by virtue of endeavoring to carry out its legitimate business of oil exploration is in some way responsible for such conflict or the level of the Nigerian government's response to them ... private companies have neither the right nor the competence to become involved" (Vidal, 1995, p. T2).

On accusations of the killings in Ogoniland, and the eventual hanging of KenSaro Wiwa, a statement on Shell Nigeria's website denies the accusation. The statement reads in part:

Although SPDC was not responsible for those tragic events, and SPDC - and Shell International in London - had attempted to persuade the government to grant clemency, the family of Ken Saro-Wiwa and others brought a court case 
against Shell. The allegations being made are false and without merit. (Shell, "Ken Saro-Wiwa")

However, newspaper reports cite what the press widely referred to as "secret documents" -company memos, faxes, letters and witness statements which emerged from court cases - as showing that "in the 1990s it [Shell] routinely worked with Nigeria's military to suppress resistance to its activities, often from Ogoniland, in the delta region, some of them ending in deaths" (Oluwarotmi, 2011, para 1; also see Vidal, 2011).

Shell also used the denial strategy to respond to accusations that it was selling some oil wells in communities that protested against their operations. A news report quotes a Shell spokesperson as responding to this accusation, describing it as "false" (Ahon, 2011, para 3). In the same report, the national president of the Niger Delta Youth Movement, Godspower Ordenema, called on the Nigerian federal government and the international community to "stop" Shell from selling the oil wells (Ahon, 2011, Para 1). The Youth leader insisted "Shell had always acted in flagrant disregard to Nigerian laws and universally accepted regulations guiding oil exploitation and exploration" (Ahon, 2011, para 7).

Shell, through its leaders and spokespersons also applied rhetorical strategies of denial, blame, and scapegoating to address oil spills. The company has consistently pointed to "sabotage" and "theft" as causes of "85 percent" of oil spills ("Shell Oil spill data"). A company spokesperson stated that a "bulk" of the oil spills in the Niger Delta were "deliberately caused for economic gain" (The Irish Times, 2005, p. 13). The 
spokesperson also pointed to raids by heavily-armed criminal gangs or "compensation scams," adding that in 2004, ninety-seven percent of spills in terms of volume was the result of "willful damage" (The Irish Times, 2005, p. 13).

Company documents also show Shell's communication focusing on attacking the accuser. The company planned to "create coalitions, isolate the opposition and shift the debate" (Lubbers \& Rowell, 2010, p. 21). This strategy aimed to "challenge" the "basis" on which opposing groups "continue their campaign against Shell in order to make it more difficult for them to sustain it" (Lubbers \& Rowell, 2010, p. 21). This is a glaring example of Benoit's attack the accuser strategy (1995, 1997; also see Coombs, 2007).

Summarily, Shell's “old approach" to crisis management in the Niger Delta relied on defensive strategies of apologia including denial, blame, and scapegoating and attacking the accuser.

\subsubsection{New Approach to Crisis (2006-2016)}

An approach to the crisis emerged which focused on rebranding the company as the "New Shell" and, as I will show, this approach strongly reflected the Discourse of Renewal. In 2006 the company brought forth a Global Memorandum of Understanding (GMoU) designed to improve its community relations. The $\mathrm{GMoU}$ is a written statement

of understanding between Shell and clusters of communities that detail roles of all parties in the implementation of community development projects. Shell refers to this document as a "new way of working with communities" (See Shell in Nigeria, "Global Memorandum of Understanding,” 2012). 
According to Shell, "the GMoU represents an important shift in approach, placing emphasis on more transparent and accountable processes, regular communication with the grassroots, sustainability and conflict prevention" (see Shell "GMoU," 2012). Shell explains this new approach as one which prioritizes upward flow of information and decisions from communities to Shell and the government levels. Thus, the GMoU presents Shell, the state, and local governments in Nigeria as actors who simply facilitate the implementation of decisions made by communities. In concrete terms, Shell describes its role in the GMoU as a "funding" and "capacity building" body ("GMoU”, para 1). Shell explains that communities "take key decisions" and "drive" their own development as they elect representatives to Community Development Boards (CDBs); these boards decide on community developments ("GMoU," para 2). Shell contends that this approach has been successful, pointing to several benefits: (1) more representative and transparent management; (2) promotes cohesion and cooperation; (3) increased local ownership and accountability; (4) increased participation, including from women; (4) encourages innovation and learning; (5) creates platform for other development actors ("GMoU", para 3). In the following section, I detail the elements of a Discourse of Renewal in Shell's "new approach."

\subsection{Shell's Discourse of Renewal}

As stated in Chapter 3, the four theoretical dimensions that inform the crisis renewal model served as the frames of analysis. The unit of analysis was specific statements made during and about the crisis drawn from data in the study (see Chapter 3 for detailed descriptions of data and procedures). 


\subsubsection{Ethical Communication}

Shell's communication strategy to frequently evoke ethical standpoints aligns with Ulmer, Sellnow, and Seeger's (2011) argument that "organizations that institute strong, positive value positions with key stakeholders, such as honesty, responsibility, accountability, and trustworthiness" (p. 215) are able to attain renewal. The ethical communication element of the Discourse of Renewal emerged as the company's leaders repeatedly pointed to virtues of accountability, transparency, and responsibility in their communication. Company officials touted the new approach to managing the crisis as a strategy that "seeks to increase transparency and accountability around project delivery and give communities greater ownership of projects from their inception" (Nwachukwu, 2015, para 14). Following an oil spill in a local community called Bonga, Shell's Country Managing Director positioned the company as a responsible organization stating that, "as a prudent corporate citizen, [Shell] will tackle all the oil its teams can see offshore or which has come onshore in this area, including oil spilled by third parties" (Global Data “SNEPCO Update on Bonga Oil Leak," 2011). In another statement, the Country Managing Director praised the company for being socially responsible, declaring that "[t]his is one of the biggest corporate social responsibility portfolios operated by a private company in Sub-Saharan Africa, and it shows that we care for the wellbeing of the communities in which we do business" (Alike, 2011, para 5).

Company leaders and spokespersons frequently communicated Shell's “commitments" to working with communities (Oyadongha, 2011, para, 5) and would frequently portray the company as an organization that fulfils promises and respects and 
implements agreements reached with clusters of communities and international bodies. One such statement declares: "[Shell] has always been committed to contributing its share of the environmental restoration fund" (Alike, 2015, para 60; also see Onukwugha, 2011; Chinwo, 2013). The ethical component of the Discourse of Renewal as enacted by Shell also had company leaders identifying the company with principles of good leadership by regularly pointing to the importance of "quality community leadership" (Chinwo, 2013, para 6), and also noting that the company "believed in value-driven partnership" with communities (Oyadongha, 2010, para 10).

Further positioning the company as a virtuous organization, Shell's communication frequently emphasized that the company promotes "capacity building" and frequently mentioned the need for community projects to have "positive impact" on the people as seen in statements by company officials (see Onah, 2010; Daily Independent, November 10, 2014; Onukwugha, 2011). In another statement that directly references virtuous behavior, an official of the company noted that "we will continue to partner with communities that are well led by notable individuals" (Chinwo, 2013).

Finally, Shell's Managing Director evoked a sense of respect and trust in a statement to the recipient communities of development projects by pointing out that "communities decide and drive their development programs while Shell provides the funding and technical assistance to implement the programs" (Onukwugha, 2011, para 5).

\subsubsection{Organizational Learning}

Shell's communication approach has consistently emphasized learning as a significant outcome of the new crisis response approach. Sellnow and Seeger (2011) 
advise that organizational spokespeople "should illustrate how the organization is learning from the crisis and what they are doing to ensure the crisis does not happen again" (p. 215). In this light, the managing director of Shell in Nigeria is quoted in a 2011 news report that Shell has "improved upon how it engaged its host communities to deliver projects and programs," adding that the company "introduced the GMoU in 2006 as a novel way of working with communities" (Onukwugha, 2011, para 4).

This statement strongly suggests the element of organizational learning and willingness to implement lessons learned for positive change. Earlier in 2010, another company official evoked the fact that Shell has learned from previous failed management approach saying "the overall purpose [of the GMOU] was to eliminate the inherent weakness in previous social performance strategies and to involve communities in project identification, implementation and management" (Onah, 2010, para 7). In a meeting in 2012 with then Nigerian President Goodluck Jonathan, following his accusations that Shell had not done enough to clean up oil spills and prevent further spills, Shell's outgoing Managing Director Brindel evoked lessons learned by pointing out that "they [Shell] have come a long way which led to the fashioning of the Global Memorandum of Understanding (GMoU)" and that the company had proactively begun to address the issues (Ogbu, 2012, para 21). Statements from company officials also frequently pointed to how they "continue to seek ways to improve" community relations (Gbemudu, 2010, para 9). As might be seen from these statements, the company positioned itself such that stakeholders perceive it as being proactive in addressing the mistakes of the past. Proponents of the Discourse of Renewal suggest organizations that engage in 
communicating learning are able to move beyond defensive communication which focuses reactively on issues of blame.

\subsubsection{Prospective vs. Retrospective Vision}

Shell's communication also exhibits elements of prospective vision as opposed to retrospective vision. Ulmer et al. (2011) explain prospective vision as a situation in which organizational leaders focus their communication on a brighter future for both the organization and stakeholders, stressing the need for leaders and spokespersons to look beyond the crisis. In contrast organizations enact a retrospective vision during a crisis by applying blame tactics, and spending more time on attributing responsibility over the causes of the crisis. Seeger, et al., call on leaders and spokespersons to communicate in a manner that emphasizes a bright future, as this could spur optimism and willingness for stakeholders to collaborate with the organization to navigate the crisis.

In many press statements, Shell officials portrayed the company as being proactive rather than defensive, focusing on the future. For example, the Managing Director and Country Chair of Shell in a 2014 news report, promoted Shell's community development projects as indications of the "company's commitment to a long-term future for Nigeria" (Alike, 2014, para 5). On another occasion, the Director said, "Shell remains in the forefront of converting Nigeria's oil and gas resources to more jobs and opportunities for Nigerians" (Daily Independent, November 10, 2014, para 5). This clearly takes away the focus of blame for a past crisis and instead directs people to anticipate a bright future with the company. Describing the performance of the company in the Niger Delta, the Country Director, speaking to communities at an award ceremony, 
explained that the development projects in Niger Delta communities "provided the best road map towards ensuring that the communities achieved socio-economic empowerment and improve standard of living" (Oduma, 2011, para 9). In another instance, the Director assured that the company's projects are "on course to significantly increasing Nigeria's oil and gas production while at the same time, delivering great benefits to the host communities" (Daily Independent, February 20, 2011, para 4). The Managing Director told communities: "We remain committed to the sustainable development of the Niger Delta" (Oyadongha, 2011, para 9). By continually evoking the terms "sustainable development" and "sustainability," Shell's communication clearly tied the company to a future that was greater than the failed past, as espoused in the Discourse of Renewal.

A Discourse of Renewal is also instantiated in the "provisional" management practices characterizing Shell's revised relations with local communities. For example, Shell Nigeria's Managing Director lauded a cluster of communities in Rivers State for "thinking outside the box" (Chinwo, 2013, para 3) in achieving a major project, adding that "this community thought outside the box and it is a unique thing" (Chinwo, 2013, para 12). Praising a community for being provisional in their tasks aligns with the emphasis on the need for organizational leaders and spokespersons to be provisional (spontaneous) as much as possible. As could be noticed from statements by leaders and spokespeople, Shell's crisis rhetoric applied the ethical element of the Discourse of Renewal. 


\subsubsection{Effective Organizational Rhetoric}

Proponents of the Discourse of Renewal call on organizational leaders to effectively structure their crisis rhetoric such that organizational publics or stakeholders can make informed decisions. The emphasis is for leaders and spokespersons to structure reality in ways that allow stakeholders to see the bigger picture rather than focusing on immediate causes of a crisis. But in doing so, leaders and spokespersons are advised to "frame the crisis in a way that inspires, empowers and motivates" (Sellnow \& Seeger, 2013, p. 98).

In almost every instance in which company officials communicated with communities, there were explicit efforts to structure or construct public perceptions of the crisis and ensuing events. Company officials accomplished this by giving a bigger picture of Shell's operations in the Niger Delta. For example, addressing some communities in the Niger Delta during the launching of electricity generation power plants, Shell's General Manager for Sustainable Development and Community Relations told the people: "We recognize that electricity is key to socio-economic development, and that is why we have implemented these projects in addition to our interventions in economic empowerment, health, agriculture and human capital development" (Vanguard, May 13, 2010, para 3). In this statement, local communities are invited to perceive a "bigger" picture of Shell by looking beyond electricity which was actually the issue in question. In another address to communities, the Managing Director stated that the company has "a history of investing in social projects and programs in many communities in the [Niger Delta] region" (Onukwugha, 2011, para 2). This statement proffers a "history" of Shell as 
invested in the welfare of communities. Another Shell official addressing local communities said, "We will continue to invest in the wellbeing of our people as we do business in the Niger Delta, and ask other stakeholders including communities themselves to be part of this noble effort" (Alike, 2011, para 16). Officials promoted this theme of caring for communities by using catch phrases such as "powering progress together" (Alike, 2011, para 3).

This rhetoric seems designed to frame Shell in ways that organizational publics are "inspired" and "motivated" (Sellnow \& Seeger, 2013, p. 98). Similarly, Shell's Nigeria Managing Director told communities that the company "shall remain in the forefront of converting Nigeria's oil and gas resources to more jobs and opportunities for Nigerians" (Daily Independent, November 10, 2014, para 5). On another occasion, the Country Director of Shell explained that a gas and oil project that was being newly created was "good news for Nigeria" ("Shell First Oil Produced from SNEPCO”, 2014, para 1) adding that being "a new source of oil revenue," the project "strengthens Nigeria's deep-water expertise" ("Shell First Oil Produced from SNEPCO”, 2014, para 1), which the Director claimed is a "key driver of economic development" (Royal Dutch Shell "First Oil Produced", 2014, para 1). These are some instances of effective organizational rhetoric that not only attempt to structure reality, but do so in a manner that motivates. Thus, Shell's rhetoric evinces this feature of the Discourse of Renewal.

Summarily, Shell's discourse of renewal aimed at portraying the "New Shell" as being more transparent, accountable, responsible, and trustworthy in its relationship with local communities. This rhetoric also sought to show that the company was now engaging 
local communities in participatory processes, as emphasis was now being placed on working with communities and allowing communities to "decide" and "drive" development projects. The "New Shell" also portrayed itself as aligning with values of "sustainability"; that is, achieving sustainable development in those communities and sustaining peace among communities. Another feature of the New Shell rebrand was portraying the company as having learned from its past crisis management approach and showing how it was implementing lessons learned (which generally has been the outcome of the Global Memorandum of Understanding). Thus, Shell's crisis communication following its official rebranding as New Shell enacted a Discourse of Renewal. The next section discusses how communities in the Niger Delta responded to the New Shell's construction of the realities of Shell's presence in the Delta.

\subsection{Response to Shell's Discourse of Renewal}

This section discusses first, how local communities in the Niger Delta responded to Shell's Discourse of Renewal; and second, the response of international NGOs to Shell's "new approach."

Some newspaper reports indicated that "New Shell" was "welcomed" in some of the communities (see Chinwo, 2013; Onah, 2010; Gbemudu, 2010; Vanguard, "Why Delta Partners with Oil Firms," December 2, 2013). But this acceptance came primarily from members of the Clusters Development Boards (CDBs) set up within the framework of the new management approach adopted by Shell, individuals who directly benefited from the company's projects. For example, praising Shell for its new management approach, the 
traditional ruler of Nembe Kingdom described Shell's Global Memorandum of Understanding (GMoU) as highly successful, and suggested that the GMoU become the gold standard for all Nigerian communities (Alike, 2011). It should be noted that for members of the Cluster Development Boards (CDBs) success meant the number of socalled development projects implemented in communities by Shell (see Alike, 2011). Shell was praised in 2011 by some members of the CDBs and individuals for executing development projects such as roads, ICT center, printing presses, and guest houses (Alike, 2011).

Members of the CDBs are in principle representatives of local communities. However, evidence emerged that suggests wealthy elites, traditional rulers, as well as local, state, and federal government partisanship often influenced the membership of these boards and this often resulted in communities protesting against members of the CDBs (see Uwugiaren, 2016; Amaize, 2016). Members were often viewed by the local people as being puppets for Shell and the Nigerian government who, more often than not, put their own personal interests and gains over those of the communities. Articulating such perceptions, some 350 "shoreline communities" declared in a joint statement cited in a Vanguard newspaper report, "We wish to inform the whole world that the GMoU chairmen/members are not invested with any authority to discuss land acquisition and/or oil spill compensation as well as convert compensation into infrastructure on behalf of impacted communities" (Amaize, 2016). The communities wanted individuals they had chosen themselves to represent their community interests according to the joint statement: "[t]he accredited representative/attorney of all the shoreline communities 
remain Gbutse Property Limited and any negotiation without the presence and/or signature of our attorney shall be deemed null and void, and of no effect whatsoever" (Amaize, 2016).

Newspaper reports also show a disjuncture between local development needs and what members of the CDBs eventually agreed on as development projects for communities. Protests often arose over the choice for development projects, over who was to determine what was best for local people, and how these projects were conceived and eventually executed. Hence, persistent conflicts, disruptions, and general opposition to Shell were evident despite the company's adoption and implementation of a Discourse of Renewal.

The notion of ownership over resources (oil, gas, land) emerged as a significant aspect that rendered Shell's discourse of renewal ineffective in the Niger Delta. A majority of the protests that eventually turned into deadly riots involved local people contesting ownership over resources. Following a 2011 riot that left three persons dead and one hundred injured, the leader of one of the protesting communities asserted: "It is a known fact that Uzere kingdom/land has been blessed with oil and gas" (para. 9). The community leader also stated that it is common knowledge that "Shell took the advantage to exploit these natural resources on our fatherland for the past 52 years" (Amaize, 2011, para 9). Protesters from Koroama community also evoked ownership over resources stating that "Shell is taking our oil" adding that "We were told that gas Shell is taking from our land is the largest, our community being the largest natural gas reserve in West Africa" (Yafugborhi, 2012, para 4). Protesters of Nembe community (whose leader had 
earlier praised Shell) held placards displaying messages such as "sale of our wealth by Shell is theft against mankind" (James, 2015, para 4). Other protesters said the company would "never operate in our land" (Folaranmi, 2015, para 8) if their community's demands were not met.

A related issue was the claim that ownership over land is "ancestral" (Iwori, 2014, para 5). As mentioned in Chapter 2, ancestral claims over ownership of land are at the heart of a conflictual situation in which host governments lease out lands to multinational corporations and these corporations are confronted by oppositional struggles from local communities who not only see the land as their inheritance, but also consider the resources on these lands (such as forest products and crude oil) as belonging to the communities. It should be noted that differential claims over land exist in parts of Nigeria even when there is a legal body charged with the regulation of land ownership. Chapter 2 details the sources of these differential claims over land including pre-colonial landownership practices, colonial administrative land reforms, and government legislature.

Shell was also accused of not negotiating with local communities. As we shall see later on, the notion of negotiation from local communities' point of view created a disjuncture in the relationship between Shell and these communities. Protestors argued that "the company did not enter into any agreement with the people" and failed "to come to [our village] to discuss" and "sign GMoU with [our] kingdom" (Amaize, 2011, para 12). Failure to negotiate was also an issue when another community justified their protest action against Shell by asserting: "The protest and the shutdown of the two flow stations 
were due to the failure of the SPDC to respect the host communities" noting that "To our greatest displeasure and dismay, we were made to understand through the media" that an oil well "has been sold out, yet we are not in the picture" (James, 2015, para 7).

The element of negotiation is also related to another point of contention: community representatives. Who should negotiate with the oil company is a critical issue in the protests Shell faces in the Niger Delta. Protesting communities continue to contest who should negotiate on their behalf and insist Shell's companies in the Niger "commence negotiation, with the proper authorized agents of the communities" (Dugbe, 2014, para 2). In one case, Shell was accused of inviting "unauthorized members of affected communities" (Uwugiaren, 2016, para 6) and for getting "chairmen of 24 communities to sign nefarious agreements on behalf of the impacted communities" (Uwugiaren, 2016, para 8). These affected communities warned that they "will definitely file a separate claim against Shell in any court of law should Shell fails to commence negotiation with our said representative/attorney" (para 18).

Local communities have mounted protests against executive members of Cluster Development Boards as was the case with the Ughelli South Local Government Area in which the Umolo-Olomu community requested that Shell should "disband" the executive body of the CDB and allow an open process that will "bring in proper executives"individuals chosen by the Umolo-Olomu community to represent the interests of this community (Ahon, 2011, para. 4). In a letter written by the Umolo community and cited in a Vanguard newspaper report, the people of this community also said they "received with great shock and strong sense of disregard, the purported inauguration of an illegal 
executive for Ughelli South 2 Cluster Development Board on Tuesday, June 72011 without any prior notice to Umolo Community" (Ahon, 2011, para. 5).

Issues of social justice and equity also undermine Shell's new approach as communities accuse the company of not ensuring "equity" in the execution of the agreements including the GMoUs. Protesting communities clearly call on Shell "to ensure that all sections of the community are fully represented in the GMoU" (Onah, 2011, para 4). Also, women and youth have protested over the "partiality in the implementation of the understanding" (Onah, 2011, para 5). Women and youth want to be part of the GMoU implementation process and have protested against their exclusion (see Oyadongha, 2010; Oduma, 2014). Gender imbalance is a particularly important factor as women continue to protest their exclusion from the implementing processes of signed memoranda of understanding. Given that Shell initiated the GMoUs, the company seems culpable on this aspect. Hundreds of women protested by disrupting operation activities at an oil facility owned by Shell in Torugbene community. The women blamed the oil company "over the alleged connivance between the male dominated leadership of the community and Shell in the implementation of the GMoU" (Oyadongha, para 2). It is the case that CDBs are dominated by men throughout the Niger Delta region.

Another issue undermining the tenets of a Discourse of Renewal in Shell's new approach was that oil spills and gas flaring continued to disrupt communities. Although Shell blamed 85 percent of oil spills on theft and sabotage, local communities have argued that it is the responsibility of the oil company to protect its network of pipelines, clean up spilled oil, and tackle the considerable amount of gas flared more efficiently. 
Farmlands, fishing grounds, and the ecosystem in the Niger Delta continue to be affected by oil spills and gas flaring. As one resident stated in a newspaper report, "The water we drink here is from the Taylor Creek, contaminated with all the pollutants which make our people sick" (Yafugborhi, 2012, para 4). Shell had also come under criticism from then president, Goodluck Jonathan, who assigned responsibility to the corporation for clean-up when he expressed "deep concern over environmental pollution in the Niger Delta owing to oil exploration" (Ogbu, 2012, para 1) and requested that Shell "urgently take measures to ensure integrity of pipelines" (Ogbu, 2012, para 1; also see Alike, 2015; Alike \& Oyedele, 2016). Thus, both the spills and flares in themselves as well as Shell's failure to adequately address them troubled the local communities and eroded the relationship between the company and local communities.

Shell's corporate social responsibility implementation approach has also been questioned. Communities have protested and accused Shell of selective implementation of community development projects - that is, executing projects in some communities and not doing so in others; signing the GMoU with some communities and not doing so with others; and abandoning and defaulting on implementation in some cases. A community leader is quoted as saying "the protest was a warning signal to the management of the SPDC to review their policy and honor existing agreements with the communities" Segun, 2015, para 7); and upon failure to do so, the community "will shut down" Shell's operations (Onoyume, 2013, para. 5; also see Oyadongha, 2016; James, 2015; BBC “Monitoring Africa,” October 5, 2015). 
Meanwhile, in response to Shell's Discourse of Renewal, international NGOs including human rights and environmental groups - accused the oil company of not being transparent and accountable despite its "new approach." An Amnesty International (USA) report accused the company of not providing factual data on the amount of oil spilled and underestimating the impact of oil spills in the Niger Delta. The report pointed to the Bonga 2008 oil spill (two years after Shell's new approach went into effect) that devastated the Bodo community, noting that the "volume of oil spilt" surpassed "more than 60 times the volume" the oil company stated was lost (Amnesty International, "New Evidence Reveals", p. 2, n.d.). The report also indicated that Shell was not being honest when it stated that the oil spill at Bonga started on October 5, 2008, when community and Nigerian regulators "confirmed" the oil spill began on August 28, 2008. Additionally, "Shell repeatedly claims to its investors, customers and the media that the majority of the oil spilt in the Niger Delta is caused by sabotage ... Sabotage is a real and serious problem in the Niger Delta, but Shell misuses the issue as a PR shield and makes claims that simply don't stand up to scrutiny" (Amnesty International, "New Evidence Reveals," p. 2, n.d.). In another report authored by Audrey Gaughran (n.d.), Amnesty International further accused Shell of "not disclosing" important oil spill investigation information. As a direct attack on what can be called the ethical elements of transparency and accountability in Shell's discourse of renewal, the report explains that "a secretly videoed oil spill investigation" showed how the oil company unilaterally "changes" the cause from "operational failure" to "sabotage" (p. 1). The report stated that this is done "with no evidence" at the end of an "official investigation" (pp. 1-2). 
Another international NGO, EarthRights International, reported that similar accusations were part of a complaint filed in the Dutch Parliament against Shell by Amnesty International and Friends of the Earth. Jonathan Kaufman, a blogger with EarthRights, stated that Shell remains under public scrutiny for "misleading the public by misattributing the blame for oil spills in the Niger Delta to sabotage rather than its own substandard practices" (2011, para. 10). Kaufman argued that Shell "consistently publicized baseless figures about oil spill responsibility" (para. 12) wherein the company claims " $85 \%$ of all oil spills in the Delta were due to attacks by militants and sabotage by Delta residents" (para. 12).

Finally, the international environmental group Greenpeace continued to accuse Shell of failing to clean up past oil spills in the Niger Delta. A report published on January 11,2015 , stated that "contamination from hundreds of past spills continues to pollute water sources and land in the Niger Delta region of Nigeria" (Keates, 2015, para 1). The Guardian's reporter Adam Vaughan on October 9, 2014, reported that Greenpeace's "sustained pressure" against Shell on the basis of environmental contamination led the toymaker Lego to "not renew its marketing contract with Shell" (para 2). Vaughan explained that this was precisely the outcome of a "viral video against Arctic drilling" produced by Greenpeace. These accusations undermine Shell's discourse of renewal, particularly its ethical claims.

Shell's new approach as a discourse of renewal was also undermined by widespread public perceptions about corruption in the company. A news report (see ICIJ, 2016) indicated that "Entrepreneurs and corrupt officials across Africa have used shell 
companies to hide profits from the sale of natural resources and the bribes paid to gain access to them" (Shane, 2016, para. 1). The news report, also asserted that "three oil ministers, several employees of the national oil company and two former state governors who were convicted of laundering ill-gotten money from the industry" are "owners of hidden companies" whose "assets cycled through Shell" (paras. 2-3). The report stated that some of the hidden assets were used to "buy yachts, private jets, Manhattan penthouses and luxury homes in Beverly Hills, Calif.” (para. 3). Such stories of largescale corruption undercut Shell's ethical claims in its communications.

\subsection{Lessons Learned}

What follows is a discussion of lessons learned in this case based on evidence that Shell's new approach and the responses it evoked from local communities can illuminate shortcomings in the Discourse of Renewal model.

(1) The Discourse of Renewal assumes a corporatist representation of reality. The organization as rhetor structures the discourse from the point of view of the corporation. The ongoing politics of representation in the model summons a corporate vision that aims at aligning affected communities to the realities constituted through corporate biases. In this case, the realities advanced by Shell spokespeople were angrily and sometimes violently contested by the local populace.

(2) Even though the model insists on a stakeholder-centered approach to crisis response, the communities in this case are spoken for by the organization. This paternalistic approach to crisis response resulted in silencing voices, community histories, and 
indigenous practices, thus effectively denying the lived realities of local stakeholders. For example, for some local communities, ownership claims over land and oil are enshrined in historical relations that do not recognize land ownership through legal instruments but through ancestral claims. Ancestors may be dead, but for local communities, these ancestors live on and are treated as members of the community. Shell failed to engage with these divergent constructions of ownership and history.

(3) The element of "significant choice" discussed in the Discourse of Renewal model is inadequate to the alternative logics-in-use in the arguments about land and oil made by local communities. The very definition of "significant choice" as a rational determination is situated in a neoliberal frame that limits the ability of corporate management to engage with local stakeholders. Accordingly, when Shell shifted from apologia to a Discourse of Renewal, the basis for organizational learning was merely a reproduction of entrenched assumptions and arguments.

(4) Shell's crisis shows that the past cannot be ignored in favor of a prospective vision. Shell's prospective vision was debilitated by obscuring or (mis)representing the corporation's past abuses, denying or ignoring the realities of local stakeholders, and maintaining a position of economic, political, and material dominance that left little option for villagers and other stakeholders other than subordination of their interests and perspectives. 


\section{Summary}

The Shell crisis in the Niger Delta is a fitting example of organizational crises that require attention to contested realities. It is also a cautionary lesson about the need for multinational communication to avoid silencing histories and muting "voiceless" people. If there is an overarching lesson learned in this crisis, it is one that can be framed in response to Spivak's question: In the Niger Delta, the subaltern cannot speak. I find that this lesson highlights the limitations inherent to the Discourse of Renewal and the need for an amendment that responds to the complexities of crises based in multinational exploitation. The next chapter examines another such crisis occurring in a similarly vexed and complex context in Cameroon. 


\section{Case 2: Herakles Farms Palm Crisis in Cameroon}

\subsection{Introduction}

The overarching purpose of this chapter is to critically analyze major points of conflict to understand Herakles Farms' corporate rhetoric in response to the crisis over their palm oil plantation in Cameroon. The focus is to examine how contextual complexities and exigencies, situational contradictions, and tenacious histories impacted the outcomes of the multinational's communication response to the crisis. I will offer an assessment of lessons learned from the company's crisis communication response, and then, a discussion of what these lessons mean for organizational crisis rhetoric and communication practices in relation to marginalized communities.

The chapter begins with pertinent aspects of the South-West region of Cameroon where the Herakles Farms operations are located. The chapter also provides a background on Herakles Farms' establishment as a company in Cameroon and the oppositional struggles against its plam plantations there.

\subsection{South-West Region}

Following is a description of the South-West region including history, governance, social and economic relations, and indigenous modes of organizing. 


\subsubsection{History}

The country that is now Cameroon was constituted by joining two separate colonial regions after their independence. French Cameroun gained independence from France in 1960 and Southern Cameroons gained independence from Britain in 1961 following a plebiscite overseen by the United Nations. It is important to note that according to the United Nations Resolution 1349, adopted at the UN General Assembly on March 13, 1959, Southern Cameroons, then a Trust territory under Britain, was to achieve independence by either voting to join the independent Federal Republic of Nigeria or to join the independent Republic of Cameroun (UN General Assembly). An independent Federal Republic of Cameroon was created following this plebiscite. In 1972, following a referendum, the Federal Republic was transformed into a unitary state. The "unitary state" appellation was later changed to the Republic of Cameroon. These regions had been previously united in the late nineteenth century when this area was colonized by the Germans in 1884 .

The country's colonial history has complicated governance and economic and social relations, particularly in regard to tensions between Anglophone and Francophone Cameroon. For example, governance follows both the Common Legal System modeled after British legal tradition and the Civil Legal System modeled after French legal tradition and cases can be tried by using either national or customary law (Garcia, n.d., para. 9). Thus the legal system in Cameroon is mired in colonialist legacies and complexities that can create tensions in litigations. It is important to note that Anglophone lawyers in Cameroon have undertaken several protest actions calling for the 
effective separation of common law practice from the civil law system (see Mbunwe, 2015). There are strong sentiments within the Anglophone part of the country that its people are being unfairly treated by the central Government dominated by Francophone Cameroonians (Geschiere \& Nyamjoh, 2000; also see Musoro, 2015). This has created a lot of suspicion surrounding particular actions by the central government on aspects affecting Anglophone Cameroon. Musoro (2015) has indicated that "[f]or decades since the independence of Cameroon, the Anglophones have constantly been in a battle of trying to negotiate their identity in the country" (para. 3). Musoro also asserted that "[t]here has always been a call [from Anglophone Cameroonians] to denounce the Frenchification of Anglophone Cameroon" (para. 3).

At the time of completing this chapter, there is an ongoing protest by teachers and lawyers of English speaking expression in Cameroon over claims of the marginalization of the English-speaking communities in the country (Andzongo, 2016). The protests have turned into riots and riot police are reported to have shot dead four demonstrators (Okie, 2016). The protests have grown to include demands for the restoration of the former twostate federation while others call for the outright breakaway of Anglophone regions from the Francophone regions (Okie, 2016, para. 2; also see BBC, "Bamenda Protests," 2016).

Anglophone Cameroonians have persistently raised what is now known as the "Anglophone Problem, a question of how to address the marginalization of the Anglophone portion of the country by the central government heavily dominated by Francophone Cameroonians. These tensions and history cannot be neglected when addressing crisis situations involving governmental actions in this region. Herakles Farms 
palm oil plantation sites are all located in the South-West Region, one of two regions that constitute the Anglophone portion of the country. The project is seen by local communities as an imposition (on their land) by the central government working in collaboration with the multinational.

\subsubsection{Political Geography of Plantation Sites}

The colonial experience in the British and French parts of the country was enacted through two different systems: indirect rule for the British and assimilation for the French (as previously discussed). However, the people of both sections of the country sustain social relations that, though not entirely similar in all aspects, are generally reflective of the country's ethnic group arrangements. Traditional institutions such as customary law, clan heads, chiefs, and communal organizing continue to organize ways of life of the people, even if the influence of these institutions and modes of organizing are being weakened by both endogenous and exogenous forces (Lockhart, 1994). There are about 250 ethnic groups in Cameroon, and close to 270 indigenous dialects (Gale, 2007). The country has 18 national parks and protected forest areas estimated to cover 2 million hectares (6 million acres) (Gale, 2007).

The South-West region currently comprises six administrative divisions, namely, Fako, Meme, Ndian, Kupe-Muanenguba, Lebialem, and Manyu. The estimated population of South-West region is nearly 1.5 million according to the 2013 population estimate (see "Regions of Cameroon"; Gwillim, 2005). The Herakles palm oil plantation sites are located in two of the six administrative Divisions of the South-West region, namely, Ndian, and Kupe-Muanenguba. Land tracts demarcated for the project are in 
Toko and Mundemba districts (also called subdivisions) in Ndian Division, and Nguti district (subdivision) in Kupe-Muanenguba Division. Appendix B shows the map of this region.

Toko district is estimated to have a population of 66,000 according to a village population survey conducted in 2011 (“Communal Development Plan Toko," 2012). Although another village study (cited in "Communal Development Plan Toko," 2012) puts the population at 14,045 , this figure is contested by local government representatives who insist the population stands at 66,000 on grounds that this was the total count following a survey conducted through Village Development Associations (p. 6). There are 49 villages in this district. Toko district has a total land mass of 103,413 hectares and much of this land is covered by forest reserves among which are Kurup National Park with a land mass of 49,105 hectares; the Rumpi Hills (5,445 hectares), and the Christian Philanthropic Community Forest $(4,928)$ (p. 7). Herakles Farms, according to a report by the Toko Council, had requested 13,303 hectares of land - this would account for 70 percent of the total land mass - leaving the communities in these areas with 30 percent of the land for farming and hunting ("Communal Development Plan Toko," 2012).

Mundemba, a neighboring district to Toko, is estimated to have a land mass of $1.557 \mathrm{~km}^{2}$ and comprises 50 communities ("Mundemba Communal Development Plan," 2012). The area has vast forest reserves including the Korup National Park, Rumpi Hills forest reserve, and a council or community forest reserve, as well as wide rivers including River Ndian ("Mundemba Communal Development Plan"; also see Herakles "ESIA 
report," 2011). The population of the area according to a field survey (as cited in "Mundemba Communal Development Plan") is estimated to be 30,044.

Nguti district has an estimated population slightly above 20,000 , and a land mass of 204,852 hectares (Rainforest Foundation, "Nguti Council,” 2016). There are 54 villages in this district. The area is covered by a council forest, three community forests, and two protected forest reserves, namely, Mbayang Mbo Wildlife Sanctuary, and Bakossi National Park (Rainforest Foundation). The Rainforest Foundation report published in September 2016 noted that local communities rely heavily on land and surrounding forests for "livelihoods" (p. 7). Communities also mostly rely on streams as sources for water supply, and as the Rainforest Foundation report put it, "poor water quality and insufficient water lines" are the immediate outcome of agro-industrial activities being undertaken in surrounding forests (p. 11).

\subsubsection{Governance}

Cameroon has a strong central government even though a semi-autonomous local government structure exists. Traditional institutions continue to play a noticeable role in local governance (Gale, 2007). The chiefs, for example, are considered as auxiliaries to the administration and coordinate with village development associations and cultural and social groups to facilitate the administration of villages or local communities. The following sub-section expands on the role of traditional institutions and associations in local communities. 


\subsubsection{Economic and Social Relations}

An important aspect of economic and social relations in Cameroon remains the significant role which community associations play in local, regional, and national life of the people in terms of economic, social, and political organizing (Yenshu, 2008). In an ethnographic study conducted on "association life" across Cameroon, it was found that association life "pervades all facets of national life" (Yenshu, p. 95) and that there continue to be a "proliferation of ethnic-based associations in the urban areas" (p. 96). These associations include regional development, village development, cultural, youth and women associations and typically identify with an ethnicity, village, or homeland. They are dominant actors in community, village, and regional development claiming to represent the peoples' interests (p. 96). Yenshu noted that “...more than a century of Christian missionary activity, colonial repression and attempts at obliteration by the postcolonial state have not succeeded in putting out the flame of association life at either the local or regional level" (p. 96). As such, Yenshu argues in the ethnographic study that "it is still worthwhile examining the value of local forces in building viable social projects if we still have to live within the pluralistic world that the imperatives of current nationstate system and the globalization process place on the diversity of peoples" (p. 97). Such associations have proliferated throughout South-West region of Cameroon including the South-West Elite Development Association (SWELA) which Yenshu studied.

Typically, governance in associations having a national spread, occur at several

levels, namely, Executive committee, General Assembly, Advisory Council or Council of Elders, and Nationwide branches (Yenshu, 2008). Such associations, according to 
Yenshu, arrive at decisions by way of "consensus" or "open ballot" as "proposals for decisions" on major issues are brought before the General Assembly (p. 109).

The people of these areas are heavily involved in communal organizing practices. For example, villages have a "Palaver House" locally called "Etane" ("Communal Development Plan Toko", 2012, p. 15). Etane is a community hall used "for conflict resolution and other social gatherings" (p. 15; see also "Mundemba Communal Development Plan", 2012). During these gatherings, discussions on community values, vision, and development prospects are discussed. There is a strong attachment to community or group organizing as these groups are enshrined in the social and economic relations of these communities. Community leaders and local government representatives rely on group associations for task accomplishment. An example of the important role these groups play in a community's operations was seen when local government representatives in these areas contested a village survey's findings that had reported the total population to be 14,045 . Instead, they supported another survey conducted through village development associations that set the population at 66,000 ("Communal Development Plan Toko", 2012).

Nguti district is not particularly different from Mundemba and Toko. Village development associations, family groups, quarter associations, including youth and women meeting groups, play an important role in the social life of communities. While associations play a significant role in community organizing, key decisions affecting the wellbeing of the community are arrived at following consultations with various 
representatives of associations, before the decisions are sanctioned by the traditional council headed by the Chief.

The relationship between the people and their traditional rulers during a crisis that pits the community against the government or multinational depends on which side the chief decides to stand. A rift quickly builds between the people and their leaders if they suspect personal interests are taking center stage on the part of these leaders.

\subsection{Land ownership}

Ordinance No. 74-1 of July 6, 1974, sets general land tenure rules and regulates ownership of land in Cameroon. Another ordinance tied to this law is Ordinance No. 74-2 of July 6, 1974, which specifically relates to the management of state land (USAID, 2010). These laws allow for individual, communal, or state ownership of land. Communal land must be registered and titled to separate it from state or national land. All unregistered land, including unoccupied land and land held under customary law is government property (USAID, 2010). A 1976 law ordinance allowed government to lease and share rents off national lands. In principle, the state receives $40 \%$ of the rent, the local Council in whose jurisdiction the land is situated gets $40 \%$, and $20 \%$ goes to the village community where the leased land is located (Assembe-Mvondo, Brockhaus, \& Lescuyer, 2013).

Within this customary law framework, "land rights are heritable" (USAID, 2010, p. 6; see Joko, 2006; Fombad, 2009). Formal courts adjudicating land matters are required to apply customary laws as applicable in Anglophone regions of the country, 
while in the Francophone regions, the jurisdiction of customary laws is to handle civil matters considered to be outside the jurisdiction of formal courts (USAID, 2010).

The land registration process can be cumbersome and expensive; this explains why only 125,000 certificates of title had been registered by 2008 , and only about 3 percent of rural land had been registered (USAID, 2010; World Bank, 2009b). It takes 93 days and 18 percent of the value of land to get land registered in Cameroon, while in subSaharan Africa as a whole, it takes about 81 days on average and 10 percent of the value of the land to get land registered and titled (USAID, 2010). Communities wanting to register land must apply to Land Consultation Boards to reclassify the land as private, failure of which such land is considered public or national with the state as administrator. The Land Consultation Boards were created as a means to decentralize land tenure in the country. Members of the board include: the district officer, a representative of the Lands Service, a representative of the Land Surveying Service, a representative of the Town Planning Service (in the case of an urban project), a representative of the Ministry concerned with the project, the chief and two leading members of the village or the community where the land is situated (Center for Environment and Development, 2013, p. 2).

Despite the existence of these legal frameworks for land tenure in Cameroon, several studies have suggested that individual and community land rights are endangered. The USAID (2010) report noted that "only a relatively small percentage of Cameroonians have registered their land rights" adding that "most continue to claim rights based on diverse customary laws, at times in direct conflict with the government, which seeks to 
use statutory law to enforce its own access to unregistered land" (p. 1). Rural communities, smallholders, pastoralists, and marginalized ethnic groups, as well as occupants of informal settlements "lack secure rights to land" (p. 2). These conflicts become manifest when the government leases land to multinational corporations who in turn, face oppositional struggles with local communities who claim ownership over land based on ancestral rights (Rainforest Foundation, 2016). This is the case with the Herakles Farms palm oil plantations.

\subsection{Herakles Farms in Cameroon}

Herakles Farms began as an American multinational corporation according to an Environmental Social Impact Assessment (ESIA) report by the corporation published in February 2011. Other sources describe Herakles Farms (HF) either as affiliated or fully owned by Herakles Capital, headquartered in New York, United States of America (“Zoom Company Information,” 2016; US Embassy Diplomatic Cables, March 24, 2014). The company targets telecommunications, energy, infrastructure, mining and agro-industrial projects in Africa (Oakland Institute "Understanding Land Investment Deals," 2012). During its initial foray into Cameroon, the Chairman and Executive Director of Herakles Capital was also the head of All for Africa, a transnational organization focusing on development in Africa (Oakland Institute "Understanding Land Investment Deals", 2012).

Herakles Farms is developing long-term large-scale palm oil production on more than 200,000 acres in West and Central Africa (“Zoom Company Information”, 2016). 
When fully developed, the palm oil plantation project "will be one of the largest commercial palm oil operations in Africa" ("Zoom Company Information”, 2016, para 1). The company was originally identified as a member of the Roundtable of Sustainable Palm Oil (RSPO), an international organization created in 2004 to promote sustainable practices in palm oil production including among others, environmental protection and inclusion of local stakeholders in the palm oil sector (see RSPO "Factsheet", 2016). Subsequently, the company left the Roundtable over its plantation plans in Cameroon. This study will use "SGSOC," "Herakles," "Herakles Farms" or simply "HF" when referring to the company.

\subsubsection{Bruce Wrobel: Benevolent Capitalist?}

The original CEO of Herakles Farms, the American investment capitalist Bruce Wrobel, articulated the presence of the company and other subsidiaries across Africa with representations that seemed to paraphrase Spivak's criticism of the white salvation ethos (see Spivak, 1988). In a tersely worded open letter to both local and international publics responding to accusations of wrongdoing by Oakland institute, Wrobel represented himself, his family, and colleagues as benevolent people, philanthropists who are interested in salvaging the people of Cameroon and the African continent from poverty, diseases, and unemployment as well as protecting young women and offering education and housing to Cameroon's and Africa's poor. He explained how his family “endured malaria, gastrointestinal illnesses, strange infections and bites from a wide range of insects and reptiles" in order to establish the palm oil project (“Open Letter," 2012, 
para.10). Here is Herakles Farms' CEO describing his mission to save Africa's 'marginalized':

I witnessed first-hand the extreme poverty caused in part by the serious conflicts in West Africa at the time. In the wake of this trip, I gathered some of the brightest and most idealistic managers and engineers I had worked with over my career, and together we made a commitment to the identification and development of specific opportunities designed to generate sustainable economic growth on a regional or national level ... We seek to identify a barrier to economic growth within a country or region, and then we design a solution which, if implemented, would eliminate the barrier and facilitate further economic activity always with the goal of building a sustainable middle class. (“Open Letter, 2012, para. 11-12)

Here we see a CEO envisioning a corporate salvation of African peoples through neoliberal economics and AngloAmerican hubris.

As CEO of the philanthropy "All for Africa," Wrobel further articulated the vision of the company through representations that aligned the beneficence of multinational capitalism with the "implementation of philanthropic projects," noting how "Herakles Farms embraced this as a great social initiative and a way to spread the benefits of our project across a much wider geography" including "everything from a school for disadvantaged girls in the Democratic Republic of Congo to a women's vocational training center in Monrovia, Liberia" (“Open Letter," 2012, para. 40). These representations of Herakles Farms as "benevolent capitalism" were strongly contested by 
the marginalized villagers in the plantation regions in Cameroon. Wrobel died on December 10,2013, but the rhetoric of benevolent capitalism continued to characterize the corporate crisis rhetoric of Herakles Farms. As I will show, the association of such a project with the ambitions of Cameroon's Vision 2035 is a disturbing example of how the fate of local communities is reframed in ways that reproduce the subordination and exploitation of those very communities.

\subsection{The Palm Oil Plantation Project}

Herakles Farms set out plans for a large-scale palm oil plantation and processing mills project in Cameroon in 2008 when a senior Herakles Farms' representative met with then Cameroonian Prime Minister Ephraim Inoni (US Embassy Diplomatic Cables, March 24, 2014). This meeting came after the company had "hired" a Cameroonian consultant to prospect land for the project (US Embassy Diplomatic Cable, B5). On September 17, 2009, Herakles Farms was established in Cameroon following the signing of an "Establishment Convention" (see "Establishment Convention", 2009; also see US Embassy Diplomatic Cable, March 24, 2014).

Herakles Farms reported in its 2011 ESIA report that the company had acquired 80,506 hectares of land in Mundemba, Toko, and Nguti in the South-West region of Cameroon. Of the 80,506 hectares, the company noted that 70,000 would be used for plantations while the remaining 10,506 hectares would be used for the company's infrastructure including factories (Herakles, "ESIA report," 2011). Of the total number of hectares acquired, 42,886 were in Nguti district, and 38,020 hectares were located in 
Mundemba and Toko districts. Herakles projected it would invest US\$760 million on the project: \$295 million on plantations and the remaining amount to be used for other operations over a 20 to 25 year-period (Herakles, "ESIA report," 2011). Herakles Farms also estimated that by 2020, the company would have developed 90,000 hectares of nurseries, implying the company would acquire more land (Herakles, "ESIA report", 2011). The Establishment Convention signed was to expire after 99 years (Achobang, 2013; also see Reuters, November 26, 2013). It also stipulated that the company would pay US\$0.50 per undeveloped hectare and US\$1.00 per producing hectare (Oakland Institute, 2016).

It is important to mention here that following oppositional struggles the company faced with local communities, government officials, and local and international environmentalist groups and organizations, the size of the land for the plantation was drastically reduced to 19,843 hectares (this marked a major point in the crisis). This was the outcome of an executive order by the president on November 25, 2013, after nearly three years of the company's operations. The executive order also readjusted land rents. Herakles Farms would now pay approximately US\$7.00 per hectare of land (Oakland Institute, 2016). This decision will be discussed at length in this chapter. The new lease according to the executive order is probationary and subject to renewal with the first expiration date being November 2016 (Oakland Institute, 2016). Herakles Farms began full operations in Cameroon in 2010, clearing forests and developing three palm oil nurseries (Oakland Institute "Understanding Land Investment Deals," 2012). 


\subsubsection{The Plantation Project Sites}

The project sites have provoked considerable contestation. Even though Herakles Farms indicated that 14,000 people would be affected by the project in these localities, a petition by Save the Wildlife Conservation Fund states that there are 38 villages within the demarcated land area where the company operates; and an estimated 45,000 people would be impacted in these areas ("Stop the palm oil plantation in Cameroon"). Further, large-scale palm oil operations disrupt the primary occupations of the people, which include subsistence farming, hunting, fishing, and collecting forest products, as well as the production of common crops like millet, cocoa, cassava, beans, rice, and fruits (Mousseau, 2012, p. 2). There are also conservation issues at these sites. The sites for the palm oil plantations are connected to protected forest reserves and parks including Korup National Park, Bakossi National Park, Banyang Mbo Wildlife Sanctuary, Nta Ali Forest Reserve and Rumpi Hills Forest reserve (Mousseau, 2012). According to Mousseau, these sites are "biodiversity hotspots" (p. 5). It is estimated that 80 percent of the World's remaining Drills are in Cameroon and the sites of the plantations are considered important habitats for this species (Greenpeace, "License to Launder," 2014, p. 3). In addition, certain areas within the demarcated areas are classified as High Conservation Value Forest (HCVF), according to Mousseau. Finally, many sacred sites (shrines) venerated by local people are located in these forests areas. 


\subsection{Herakles Farms Crisis}

Similar to the Shell case in Nigeria, Herakles Farms in Cameroon is facing an ongoing crisis of confidence and a breakdown in organizational operations. These crises disrupt organizational routines and pose heavy threats to the survival of the organization. And just as in the Shell case, Benoit's $(1995,1997)$ two conditions in determining whether or not an organization is in a crisis hold true in the Herakles Farms situation: first, Herakles is accused and held responsible for actions or occurrences; and second, these actions or occurrences are considered offensive by Herakles' stakeholders (see Benoit, 1997, p. 178).

The crisis confronting Herakles in Cameroon has two phases/periods. The first period dates back to the early years of its operations in Cameroon (2009-2013). This period covers the company's early struggles with government officials concerning the legalization of the company's operations. This period was also marked by oppositional struggles with villagers and environmentalists (local and international NGOs). The second period of the crisis runs from 2014-2016. During this period, oppositional struggles with villagers and environmentalists (local and international NGOs) intensified. To better situate the complexities and situational exigencies in this crisis, these two periods of the crisis are discussed separately. 


\subsubsection{Crisis Phase I (2009-2013)}

Three actors - the host government, the villagers, and the environmentalists (local and international NGOs) - vigorously opposed Herakles Farms' palm oil plantation project during this period.

\subsubsection{Government Opposition to Herakles Farms}

Government opposition came particularly from the Presidency of the Republic; the Ministry of Forestry and Wildlife; and the Ministry of Agriculture, Planning and Rural Development. These institutions must be involved in "development" projects in the forestry and agriculture sector that cover vast forestland in the country.

In May 2011, the Presidency of the Republic of Cameroon, "rejected" a land title application from Herakles Farms on the grounds that the land title application needed “additional review" (US Embassy Diplomatic Cables, March 24, 2014). Officials in the Ministry of Agriculture and Rural Development stated that the "primary problems" with the Herakles' project had to do with the "size and location" which is "adjacent to several national parks and protected areas" (US Embassy Diplomatic Cables, March 24, 2014, B6).

By this time, the company had already begun developing the forestland for the project. The Ministry of Forests issued a stoppage order against the clearing of forestland by the company on February 1, 2012 until the company provided "supporting documents that empower" the company "to proceed with the clearing" (Regional Delegation of Forestry, February 1, 2012). The Forestry official's correspondence also highlighted the 
need for a map that clearly identified the area to be cleared. Herakles was also accused of extending $1 \mathrm{~km}$ (1.6 miles) outside the land prospected for the project. The Ministry of Forestry also accused the company of unlawfully felling trees (Regional Delegation, 2012). The Ministry issued a subpoena for the company to appear before an investigating committee on April 25, 2012.

Another charge against Herakles by the Ministry of Forestry was that the company's palm oil project was directly competing with the livelihood of the local population. The Ministry also stated that "the loss of opportunities offered by forest resources" is huge compared to a "few precarious employments in the plantation" (Ministry of Forestry, "Fact Finding Mission Report”, 2013, para 1).

On April 22, 2013, Cameroon's Ministry of Forestry issued an order stopping Herakles Farms operations in the country. The US embassy in Yaoundé, in diplomatic cables released on March 24, 2014, quotes an "independent forest observer" recruited by the Government of Cameroon who justified the stoppage order: "SGSOC conducted tree felling without authorization inside the permanent forest estate" (B7(A)). The forest observer added that "SGSOC did not follow the procedures and legal terms guiding the alienation of permanent forest estate" (B7(A)). The diplomatic cables also quoted the forest observer as saying "the Ministry of Agriculture and Rural Development and the Ministry of Forests and Wildlife were not associated to the implementation of the [...] project in the area requested, according to the regulations in force" (B7(A)). The stoppage order from the Ministry of Forestry carried a US\$50,000 fine as penalty, and “condemned the tree-cutting as illegal" (US Embassy Diplomatic Cables, March 24, 
2014, B7(A)). The order also "required HF to renegotiate its Establishment Convention" (US Embassy Diplomatic Cables, March 24, 2014, B7(A)). On May 18, 2013, Herakles Farms announced in a press release that it was suspending its operations in Cameroon and laying off 690 workers (Musa, 2013; Hinshaw \& Tumanjong, 2013; Makia, 2013; Viban, 2013).

\subsubsection{Community Opposition to Herakles Farms}

Early opposition to Herakles farms by villagers emerged in 2009. The first recorded community opposition came from the Batanga community in Ndian (Mundemba and Toko Districts) division. This community opposed the issuance of a land certificate to Herakles "on all lands presently owned and occupied by the Batanga" (para 1). The communities raised worries over the destruction of their forests should a land title be issued to Herakles Farms. The local communities also pointed to problems of environmental degradation and stated that "we find this current move to deforest our lands by Sithe Global Sustainable Oils contrary to the preservation of the biosphere" (Mbile, 2009, para 3).

As community opposition grew against the company, between 2010 and 2012, there were 26 recorded petitions in which villages sought to or effectively did stall the operations of Herakles Farms. Issues raised in these petitions revolved around the loss of farmlands (a major source of livelihood), "abusive invasion" of sacred shrines, and destruction of forest products (another source of livelihood) (see Ngoe, 2010; Fabe, 2011a; 2011b; Masaka, 2012; Bita, 2012). Besides the issue of land loss, local communities stalled the company's operations for "developing land without the consent 
of the communities that surround and depend on it" (Cannon, 2016, para 1). In 2012, villages in the surrounding operations area of the palm oil plantation project accused Herakles of "grabbing communal land" and land which they said was inherited from their ancestors (Opio, 2012, para 7).

\subsubsection{Oppositional Struggles by Local and International NGOs}

Local and international environmental organizations including SEFE, Oakland Institute, and Greenpeace charged the Herakles project for non-compliance with guidelines on environmental protection. Baboon populations in the region as well as water rights issues were reported to be at stake. Notably, the Herakles Farms environmental and social impact assessment report indicated the potential danger to the quality of groundwater as a result of the chemicals and fertilizers and pesticides that would be used in the plantations sites (see Mousseau, 2012, p. 2).

The Oakland Institute, an environmental conservation agency based in California, published a report in 2012 detailing the impact of Herakles palm oil plantation and calling the project a "deceit" of local communities. The NGO noted that the Herakles palm oil plantation project would lead to "irreversible environmental impact" since the area of the company's operations is "an important area for high biodiversity" (para 15). The Oakland institute report also pointed to the displacement of village populations as a major potential impact of the project. The organization accused the company of "the destruction of livelihoods for thousands of Cameroonians" (para. 8) and stated that because the primary occupations in these villages are farming, hunting, fishing, and 
collection of forest products (e.g., wild food, medicinal plants, and fuel wood), Herakles Farms palm oil plantation project would result in loss of livelihood (para. 8).

Greenpeace, in a press release of February 19, 2013, accused Herakles Farms of undertaking a project that would result in "massive carbon emissions and the destruction of habitats critical to threatened animal species" (para. 1), and stated the company must be "stopped" (para. 1). The Greenpeace press release also quotes a local Cameroonian environmentalist, Nasako Besingi, Director of Struggle to Economize Future Environment (SEFE), a local NGO, who stated that "the proposed plantation is located between five protected areas and any attempt to open it up will have catastrophic effects on the environment" (para. 5). Greenpeace and Oakland Institute also reiterated accusations of land grabbing which communities had already raised.

Along with environmental concerns and stripping local communities of land, there were accusations of corruption and intimidation of villagers who opposed the plantation project. On corruption allegations, Greenpeace, in a report published on September 6, 2016, pointed to allegations that Herakles Farms "used bribery" and the "promise of future benefits to certain individuals to obtain support from local communities and administrative authorities" ("Herakles Farms chaotic history," p. 5). Greenpeace also cited another study conducted by the Ministry of Forestry in 2013 which found that land negotiations were done "with [a] lot of intimidation and bribery, targeting the chiefs and some few influential decision-making members of the communities" (p. 5). The Greenpeace report also cited a French newspaper, Le Monde, in which the Director of Operations for Herakles' subsidiary (SGSOC) at the time "promised to secure 
employment for family members of a high-level employee" (p. 5) who worked with Cameroon's Ministry of lands. According to US Embassy cables there were accusations that suggested Herakles Farms "may have violated the Foreign Corrupt Practices Act" (B6).

Regarding accusations of intimidation, the company came under criticism for arresting and putting into detention villagers who protested its operations. Greenpeace, in a report on May 3, 2013, stated: "When residents protested against the plantation ... they met with intimidation and arrests" (p. 5). The Greenpeace report also noted that in November 2012, when members of the local environmental NGO SEFE and their leader prepared "a peaceful demonstration" they were "arrested" at the NGO's main office and "held without charge" (p. 5).

However, on November 25, 2013, Cameroon President, Paul Biya, signed a decree allowing Herakles to carry on its operations on 19,843 hectares (49,033 acres), down from the initial 73,086 hectares the company had already prospected. The decree described the nearly 20,000 hectares as a "temporal concession" to the company (Achobang, 2013, para 1). A Reuters news report of November 26, 2013 stated that the decree required that Herakles pay US\$408,600 as land tax (Djoyum \& Bate, 2013). Herakles memos had earlier stated that the government of Cameroon agreed to a 99-year land lease with the company (also see Hinshaw \& Tumanjong, 2013).

Summarily, the major accusations Herakles faced in the first phase of the crisis in Cameroon revolved around disrespect of Cameroonian law, land grabbing (including loss 
of livelihood for communities who rely on farmlands and forest products to survive), destruction of forest reserves and biodiversity, particularly endangered animal species (e.g., baboons, drills), corruption, and intimidation and arrest of protesters.

\subsubsection{Crisis Phase II (2014-2016)}

Once Herakles Farms obtained its authorization from the Cameroon President, oppositional struggles came primarily from local communities and environmental groups. But because the company's community relations had severely been damaged, operations were stalled. Herakles Farms in this period gradually shifted attention to timber logging and exporting to foreign markets including China (Greenpeace, "License to Launder", 2014).

Environmental activists accused Herakles of illegal logging on grounds that the company was not registered as a timber company. Their reports also cited the "Establishment Convention" in which it is suggested that all trees felled during the clearing of forests would be handed over to the government of Cameroon. One Greenpeace report quotes a Herakles official who in 2012 said, "As we are not commercial loggers, we will cut it, trim it and stack it for the government" ("License to Launder,”2014, p. 7). Yet in 2014, Greenpeace reported that Herakles was facing "financial difficulty" and was turning to illegal logging ("License to Launder," 2014).

On May 29, 2015, Herakles Farms abandoned "all operations" in Mundemba and Toko in Ndian division according to a press release by the local NGO SEFE published on the website of Forest Peoples' Program ("Herakles Abandons All Operations," 2015; 
also see Ndi, 2015). The release quoted a spokesperson of the company who blamed management for "prioritizing timber extraction over planting of palms" (para. 2). An environmental reporter in Cameroon, Manka Grace, confirmed that Herakles Farms "no longer have an office" in the location (personal communication, July 20, 2015). Manka added that the signboard of the company "together with office properties" had been moved (personal communication, July 20, 2015).

Evidence of a Herakles reorganization was reported by Greenpeace on September 15, 2016. Herakles reported new investors and a new Chairman and General Manager, Jonathan Johnson-Watts, who was installed in November 2015. The Greenpeace report also mentioned that "Herakles Farms is confirmed to have sold SGSOC to new investors" (p. 9). Johnson-Watt and his business associate James Stevenson-Hamilton are shareholders of several UK registered companies. It is important to note that they are both also directors of Volta Red Ghana. Volta Red Ghana is the new company that has taken over Herakles Farms palm oil plantation project in Ghana following similar community oppositional struggles (see "Herakles Farms' Failed Venture Ghana," 2014).

Oppositional struggles against the company continue. Some 244 farmers in Cameroon, on September 27, 2016, filed complaints against the company for "trespassing" ("244 Cameroonian farmers," para. 1; also see Ngalame, 2016). The complaints filed in the Court of First Instance in Bangem (Nguti), one of the administrative districts hosting Herakles Farms operations, accused the company of failing to "respect a $5 \mathrm{~km}$ buffer zone around their farmlands" ("244 Cameroonian Farmers,”2016, para. 2). Greenpeace claimed that the initial land demarcated by 
Herakles "encroaches on many farms in the forest areas" ("244 Cameroonian Farmers," para. 2).

Summarily, this second phase of the corporate crisis faced by Herakles Farms in Cameroon entailed principally accusations about illegal logging and land grabbing.

\subsection{Herakles Farms Crisis Management and Communication Approach}

The discussion in this section focuses on the communication process with which Herakles sought to engage stakeholders in addressing the oppositional struggles they encountered.

\subsubsection{Phase I Crisis Communication Response}

During Phase I of the crisis, the company responded to accusations and confrontations with rhetorical strategies that denied the legitimacy of the claims levied by opposing government officials, local communities, and international environmental organizations. However, while the denial strategy dominated the company's communication, other strategies used by company leaders included: transcendence, bolstering, differentiation, and ingratiation. These strategies emerged during the coding process described in Chapter 3. I elaborate on these strategies in the following paragraphs.

Company leaders denied accusations that they were operating illegally and in disrespect of Cameroonian laws. In two Open Letter webpage entries addressed first to the public in September 2012 and then to investors in March 2013, then CEO Bruce 
Wrobel stated, "Herakles Farms has a long-term agreement with the government of Cameroon [and had acquired] all necessary consents, approvals and permits required to operate legally within the country" ("Investment Opportunity," p. 3). Company executives also denied allegations that the company was facing opposition from the government. Herakles told investors that the project has "Strong government support and commitment," which they explained, "is a result of the Cameroon Plantation providing an economically underdeveloped region of Cameroon with decades of large scale employment and needed infrastructure including roads, schools and hospitals" (“Investment Opportunity,” 2013, p. 3).

In response to accusations that the company was grabbing land and stripping locals of their land rights, hence taking away the source of livelihood for village communities, the company denied these allegations. Instead, in another response published on March 20, 2012, it was stated that the company is committed to "not planting on land where villages and farms currently exist, leaving land for their future generations' expansion, as well as buffer zones to ensure plantation operations do not impact them" ("Response to Inquiries," p. 4). The company also stated that "in the few cases in which villages have wished to be excluded from the plantation area, we have accommodated these requests by removing the land from our leased area" ("Response to Inquiries," 2012, p. 5). Yet in 2011, an Environmental Social Impact Assessment (ESIA) study conducted on behalf of the company pointed out that "traditional livelihood activities inside the Concession such as subsistence agriculture, gathering and use of NTFPs [non timber forests products], and hunting will be adversely impacted by the 
Project due primarily to the loss of land available for these activities" (ESIA, 2011, p. xxvii).

Addressing accusations of environmental (biodiversity) destruction, Herakles Farms denied these allegations and clearly stated in an Open Letter in September 2012 that "none of the distribution maps showing important areas of birds, mammals, reptiles, amphibians and plants showed the project site as an important biodiversity conservation site" (Herakles Farms, 2012). The company not only denied the allegations but also shifted blame to local communities" farming methods, stating that "we recognize the value of the environment which surrounds us, its importance to the local people and to the global community" ("Herakles Exposed," 2013, p. 6); further, "activities that have contributed to the area's reduced biodiversity include [past] logging in some places, and small scale farming in others" (p. 6). The company said "slash-and-burn small-scale agriculture and other unsustainable practices have enhanced land degradation" ("Herakles Exposed," 2013, p. 6). The company explained that the location for project sites was chosen, among other criteria, because the land "had been previously logged and is not covered by any existing ecological protections, thereby enabling SGSOC to build-out a sustainable oil palm operation" (ESIA, 2011, p. xiii).

A rhetoric of denial was also applied to the corruption charges made against the company. The company cited the anti-corruption policy of the organization, asserting "Corrupt business practices will never be tolerated at Herakles Farms" (Anti-Corruption Policy, cited in "Herakles Exposed," 2013, p. 2). In another response, the company stated: 
Herakles Capital and SGSOC take corruption very seriously. All of our employees, contractors and subcontractors are required to sign a document committing to compliance with the Foreign Corrupt Practices Act (FCPA), and as an American company that utilizes multilateral financing, we cannot afford to engage in or be associated with any corruption (nor do we wish to partake in such activity) (“A Response to Inquiries,” 2012, p. 6).

The Company responded to accusations of illegal logging by denying it was involved in logging: "We surrendered the timber to the government ... We are not commercial loggers. We will cut it, trim it and stack it for the government" ("Open Letter," 2012, as cited in "Herakles Exposed," 2013, p. 1). There was a subtle shift in the company's response to the allegation of illegal logging in 2013. The company stated: "We would also like to clarify that our company only has rights to the area's timber and natural resources as needed for the plantation's development. Therefore, any timber that we fell beyond that amount is for the government's use and sale" ("Herakles Exposed," 2013, p. 1).

The company also used the strategy bolstering. This strategy was used in statements pointing to other sectors of the African economy where the company was doing well. Other statements pointed to the good characteristics of the company and its CEO; yet, other statements reminded and even praised stakeholders for standing with the company (see Coombs 2007). For example, the creation of the company was depicted as beneficial and sustainable for Africa: "Inspired by a desire to 'do something' for Africa after a visit to war-torn West Africa in 1999, our CEO, Bruce Wrobel, quit his job to start 
Herakles Capital with a commitment to using his skills in large-scale project development for the benefit of sustainable economic development in Africa" ("Response to Inquiries," 2012, p. 1). The company presented its successes in other sectors: "Herakles Capital has helped found several award-winning projects across the continent, bringing numerous benefits to the corresponding regions... and we are developing our latest project, SGSOC, in the same spirit" ("Response to Inquiries," 2012, p. 1). This is also an example of what Coombs calls the bolstering sub-strategy of "reminder" (2007, p. 170). Thus, there is evidence of rhetorical strategies seeking to enhance the company's public reputation.

The company praised some stakeholders in order to advance a social responsibility image. For example, Herakles Farms praised the government of Cameroon for its Free Trade Zone program stating that "such incentives are important to attract foreign investment to supplement the fragile investments the state is capable of making," adding that "the region in which we operate has very little cash in the economy, as most of the population lives subsistence lifestyles" ("Response to Inquiries, 2012, p. 4). The company also stated that "the government alone cannot develop markets in the area, and taxing these people is nearly impossible when they operate in an informal economy with very little cash income" (p. 4). In another statement, Herakles Farms praised the women in a village community called Fabe. While the village had opposed its operations, the company's website applauded a Women's Day ceremony acknowledging SGSOC. The company stated: "For International Women's Day this year, we were honored that the women of Fabe in Mundemba district demonstrated their appreciation for SGSOC's presence with a ceremony" ("Response to Inquiries," 2012, p. 5). Coombs (2007) has 
referred to this kind of crisis communication strategy as "ingratiation" (p. 170) which is a sub-strategy of bolstering.

The company also used a strategy called differentiation (see Benoit, 1995, 1997; Harlow et al., 2011, p. 81). In this strategy, organizational leaders and spokespersons talk about the differences between the company's actions as compared to similar acts that might have occurred in other sectors or with other companies especially competitors. For example, in a statement to stakeholders, the company stated:

Unfortunately, we launched this project at a time when there have been an increasing number of speculative investors seeking land in African countries. Given some examples that have been set by others, we understand that the investment incentives we have been awarded have attracted the attention of critics" (“Response to Inquiries,” 2012, pp. 3-4).

This statement clearly sought to separate Herakles Farms operations from other companies in the same sector.

Another strategy the company used in its crisis communication is transcendence. According to Benoit (1995, 1997; also see Harlow et al., 2011), companies use this strategy when they position the act in a different context. Company leaders tell stakeholders to focus on a broader context within which the act occurred. In the case of Herakles Farms, the company attempted to situate the palm oil project in a bigger context so that communities might clearly see the benefits of the project. For example, the company stated that "through its work in Africa, Herakles Capital has identified food 
security as one of the major issues, and responding to the interest of the Government of Cameroon in being self-sufficient in basic food staples, Herakles Capital launched the SGSOC project in 2009" ("Response to Inquiries," 2012, p. 3). In this statement, the company situated the company within the context of "food security," an issue of local, national, and global importance.

It should be noted that bolstering, transcendence, differentiation, and ingratiation are strategies used to "reduce the offensiveness" of the crisis as perceived by organizational publics/stakeholders (Benoit, 1995, 1997). In other words, Herakles Farms used rhetorical strategies aimed at reducing perceptions of corporate wrongdoing and promoting an image of social responsibility and beneficence.

\subsubsection{Phase II Crisis Communication Response}

In Phase II, the company made a major shift in its approach to communication and crisis management. The approach emphasized elements in the Discourse of Renewal model as discussed in the next section.

\subsection{Herakles Farm's Discourse of Renewal}

\subsubsection{Ethical Communication}

Ulmer, Sellnow, and Seeger (2011) stated that "organizations that institute strong, positive value positions with key stakeholders, such as honesty, responsibility, accountability, and trustworthiness" (p. 215) are able to attain renewal. This ethical element of the Discourse of Renewal is evident in recent communications by Herakles Farms' leaders and other spokespersons. Speaking to the press following a joint 
governmental ministerial commission to assess the operations of the company in the project sites, a Herakles Farms' executive evoked such positive value positions by indicating that the company would be transparent in its relationship with local communities. The company executives stated that the company will "work with cooperatives societies and allow small scale holders to fully participate in the project" (Mvogo, 2016c). Cooperative societies as seen in this quote are "small scale holders," that is, local palm oil and other agriculture product producers in these communities.

These "small scale holders" are the backbone of community organizing in these communities. Communicating openly with these groups strongly suggests that the company was aiming at positioning itself as a transparent organization. The company executive also sought to align the company with being socially responsible, noting that Herakles would "train" small scale holders, "give certain privileges and amenities" to communities and undertake "timely salary payment" of workers from the surrounding communities (Mvogo, 2016c). In 2012, then CEO, Bruce Wrobel hinted at this ethical component in a news report published on June 12, but that discourse was eclipsed by increasingly defensive communication strategies which the company strongly adopted. For example, in the June 2012 news report, Wrobel stated: "Herakles Farms is committed to listening to the concerns of all stakeholders and modifying our practices where necessary. We want to be a responsible leader in developing sustainable agriculture that prioritizes community development" (Rothenberg, para. 6). Wrobel also stated, "Going forward, we want to foster greater openness, transparency and collaboration in our activities" (Rothenberg, para 6). 


\subsubsection{Prospective vs. Retrospective Vision}

The Discourse of Renewal suggests that organizational leaders and spokespersons communicate by focusing on a brighter future, a future that is more promising than looking back on the past. Leaders should not engage in defensive communication; they should avoid blame tactics, and instead show stakeholders that a more important future is achievable, that the crisis is actually an opportunity for growth and renewal. A company spokesperson stated in a news report that "in the future we plan to spend about 29 billion" (Mvogo, 2016d) and also told stakeholders that the company was now fully focusing its efforts on developing the plantations in a sustainable manner (Mvogo, 2016b). Another spokesperson in another news report stated that "there are new shareholders who have joined the company" (Mvogo, 2016b). This further communicated the notion of renewal through a prospective focus.

\subsubsection{Organizational Learning}

The Discourse of Renewal model prescribes that leaders "should illustrate how the organization is learning from the crisis and what they are doing to ensure the crisis does not happen again" (Sellnow \& Seeger, 2011, p. 215). In this regard, it is significant that Herakles' new communication approach was framed as a "revamped impetus" (Mvogo, 2016b). The company officials acknowledged that the problems of the past were a result of the company not having "duly respected" norms of forest exploitation, and also asserted that if further clearing of the forest for plantation land was to be undertaken, this would be done "reasonably" (Mvogo, 2016a). This clearly suggests that the company had learned from the crisis about forest clearing and environmental protection. 
To show how the company was willing to enact changes to rectify and avoid future problems, a Herakles Farms executive stated that "environmental considerations are now given due attention to right the wrongs of the past" (Mvogo, 2016a). The company executive also stated that "we have two environmentalists who are with us right now in the country and he [sic] is really tackling that particular area" (Mvogo, 2016a). Further, addressing one of the most contentious aspects in the crisis, the company official mentioned that "about 30 percent of the concession area would be preserved" to ensure that biodiversity is protected (Mvogo, 2016a).

\subsubsection{Effective Organizational Rhetoric}

The Discourse of Renewal suggests that organizational leaders effectively structure crisis rhetoric such that organizational publics or stakeholders can make informed decisions. Leaders and spokespersons are advised to "frame the crisis in a way that inspires, empowers and motivates" (Sellnow \& Seeger, 2013, p. 98). The new crisis rhetoric that Herakles Farms adopted was more measured compared to previous crisis rhetoric. There were visible attempts to contextualize the crisis in ways that indicated the company was moving beyond the crisis. Company officials sought to communicate a "bigger picture" for events surrounding the crisis. For example, one of the company's executives framed the palm oil project as a community project stating that the company is "encouraging small scale holders to develop individual farms to become an integral part of the palm project" (Mvogo, 2016c).

Summarily, the Discourse of Renewal endorsed by Herakles Farms was a clear contrast with its previous crisis rhetoric that was both defensive and reactive. The new 
communication approach aimed at rebranding the company in ways that suggested to stakeholders that the company was adopting a more ethical stance to management and that the company had learned and was willing to implement lessons to prevent future crises. The company's rhetoric was more optimistic and future oriented. The ethical dimension of the discourse sought to effectively align the company with important community values including transparency. The following section is a discussion of how local communities and international environmental organizations responded to Herakles Farms' Discourse of Renewal.

\subsection{Communities' Response to Herakles Farms' Discourse of Renewal}

Herakles Farms’ Discourse of Renewal failed to convince local communities and international environmental organizations. In public venues, Herakles Farms adopted a new communication approach beginning in January 2016. By September 27, 2016, some 244 local farmers filed "two collective complaints" against the company (Greenpeace, "244 Cameroonian Farmers," 2016, para 2). The farmers argued that negotiation did not occur between local communities and the company before lands were given to the company. A villager stated: "One day, I came to my farm and I found that they had bulldozed everything. I knew I was going to develop this place to earn my living and when I die, my children would remain there, but today, I have no place. We are all crying here, and we don't know how we can be rescued" (Greenpeace, "244 Cameroonian Farmers," 2016, para. 4). Cannon (2016) quotes a former local government official in Mundemba who pointed out that the company started work on the lands "without local 
communities' knowledge" (para 20). At issue is how negotiation is understood within these local communities.

In the same report by Greenpeace (2016), Sylvie Djacbou, a Cameroonian environmental activist, reiterated charges earlier raised against the company: "SGSOC violated the law many times and didn't fulfill the numerous promises they made to the communities, such as the building of roads and schools, so one can't think how they could improve" (para. 8). Djacbou also emphasized "always protecting local communities and the great biodiversity that surrounds them," characterizing the company as "a destructive project" which "must end" (para. 8). She also pointed to earlier accusations made against the company: "SGSOC activities are tainted with illegalities: not only does their establishment convention with the Cameroonian government violate the law, but they also cleared the forest without a permit, intimidated several traditional chiefs and used bribery and promises which are yet to be realized to obtain local authorities' favor" (para. 7). Thus, despite the company's attempts at renewal, activists and community members remained disaffected by the company's rhetoric.

In another report published on April 7, 2016, author John Cannon quotes a French agronomist-geographer, Laurène Feintrenie who had worked in Cameroon with CIRAD, the French agriculture and development research organization. Feintrenie stated that "informed consent of local communities" was not sought "at all" ("Lessons from Herakles," para. 6). The French agronomist is quoted praising community actions, noting that it was a good thing that local communities stood up to "the abuses of the government and the company" (para. 8). 
Meanwhile Greenpeace stated in its October 4, 2016 report that, together with a coalition of NGOs, it has launched a petition in Cameroon and outside the country calling on the government of Cameroon "not to extend nor to renew" the provisional land lease issued to Herakles Farms through a presidential decree ("244 Cameroonian Farmer," 2016, para. 7). Clearly, the Discourse of Renewal enacted by Herakles Farms in Phase II of the crisis did not resonate with local communities. Oppositional struggles continue as seen in the suit filed against the company by 244 farmers from communities within the operation areas of the company barely months after the company executives and spokespersons emerged with a Discourse of Renewal.

\subsection{Lessons Learned}

What follows is a discussion of lessons learned in this case and the limitations of the Renewal model.

(1) Herakles' Discourse of Renewal failed to address the socio-cultural, communal modes of organizing characteristic of communities within which the company's operations occurred. Communication failed to reflect the important role of traditional communal institutions that bond these communities.

(2) The company's focus on community titular leadership failed to acknowledge how communities themselves identified leaders. There is need to attend to the situationality of leadership, what it means to be a leader in these communities, and how leadership is represented or constituted. 
(3) The company's prospective vision failed to address the past (history) of these communities. Oppositional struggles over land ownership are situated within an ancestral past that justifies community land rights based on ancestral ties irrespective of the existence of legal instruments regulating ownership of these resources.

(4) The Discourse of Renewal was overly organization-centric. The organization as rhetor structures the discourse from the point of view of the corporation. The ongoing politics of representation in the model summons a corporate vision that aims at aligning affected communities to the realities constituted by corporate systems of representation.

(5) The belief system of a people is an indispensable variable in an effective communication approach that aims to address situated exigencies. Communities accused the company of disregarding their ancestors by demarcating forestland that cuts across ancestral shrines. Ancestors are considered part of the community.

\section{$\underline{\text { Summary }}$}

Contestations over land ownership by communities, land grabs, destruction of livelihood, manipulated negotiation, environmental degradation, illegal logging, and intimidation, unlawful arrest and detention and accusations of disrespecting Cameroonian law were at the center of the crisis. The company generally denied accusations from local and international stakeholders. A change in communication strategy and crisis management that, whether intentionally or not, endorsed a Discourse of Renewal, did not remedy the situation. The lessons evince the limitations of the model. In the next chapter, 
a philosophy of Africentric communication and its principles is reviewed in order to consider whether such a perspective might usefully amend the Discourse of Renewal. 


\section{African Communication Concepts}

\subsection{Introduction}

This chapter conducts a review and critique of concepts drawn from African communication philosophy. The overarching goal is to address the second research question: which elements of Afri-centric communicative principles are most salient to a multinational crisis renewal response? The case analyses in Chapters 4 and 5 showed that the crisis renewal model is not universal and must address both crises and communicative relations more responsively. The larger significance is rethinking the Discourse of Renewal through multiple frames of knowledge, history, ethics, and power in order to develop a more contextually and situationally responsive model. This chapter therefore introduces African communication philosophy and considers how the principles of such a perspective apply to the corporate crisis response.

\subsection{Review of African Communication Concepts}

African communication scholars generally agree that communicative practices are situated geopolitically, culturally, and historically and they advocate for a paradigm that reflects the structure and relations of African communities. Faniran (2008), for example, thinks communication education in Africa "remains largely an import from Western Europe and North America" (p. 146). For Faniran, Africa needs a communication framework that can be said to be "homegrown" (p. 146). It is against this backdrop that African communication scholars propose an "indigenous paradigm" which conceptualizes communalism as paradigmatic to communication in Africa (Faniran, 2008, 
p. 146; also see Ansu-Kyeremeh, 1997, 2005; Tarawalie, 2008; Wilson, 2008; Langmia, 2013).

This conceptualization posits that communication is "primarily concerned with confirming, solidifying, and promoting the communal social order, while its secondary purpose is to maintain or improve interpersonal relationships" (Faniran, 2008, p. 152). Thus, communication exists as "human interrelationships that build up the community" (p. 153). For Faniran, communication cannot be separated from communalism as there is a "consensus" among African scholars that "the powerful, taken-for-granted framework of understanding or the root paradigm of these [African] cultures remains communalism" (p. 150; also see Ikuenobe, 2006; Famakinwa, 2010; Oyeshile, 2004). As such African cultural communalism is seen as the "template for African communication" (Faniran, 2008, p. 149). Ansu-Kyeremeh $(1997,2005)$ also argues for the communalistic nature of communication by explicitly calling for a return to small group, interpersonal, community-oriented communication structures. To paraphrase Ansu-Kyeremeh, communal communication basically is small group-oriented, rooted in the local culture, dialogical, interpersonal, instantaneously produced, interactive, and "utilizing concurrently the senses of sight and sound in face-to-face encounters" (p. 20).

Other scholars who support communalism with an emphasis on its participatory character include those who have vigorously called for the revalorization of indigenous knowledge systems in communicative practices (e.g. Mogweku, 2013; Awotiya, 2013; Langmia, 2013). 
Scholars advancing the communal paradigm insist relations in African cultures are tied to duties that emphasize the moral supremacy of the community, such as respect for community values, sensitivity to the plights of community members, and respect for the elderly (Gyekye, 1997, 2003; Famakinwa, 2010; Ikuenobe, 2006). Hence, communication's primary purpose is to foster these humanistic duties. These duties are enshrined in community values that emphasize the common good of the community and include mutual aid, caring for others, selflessness, interdependence, solidarity, reciprocal obligations, social harmony and mutual trust (Oyeshile, 2004, pp. 294-295). Oyeshile explains the importance of these communal values noting that "it is these values that define and guide the social relationship in the form of attitude and behavior that should exist between individuals living together in a community" (p. 294). Oyeshile is explicit in his call for a return to these communal values if Africa is to overcome its slow development.

However, it is important to note the differential perspectives underpinning the practice of communalism in cultures across Africa. For example, while African communication scholars and African philosophical thoughts agree on the communal character of African communities, there are also disagreements on the nature or manifestation of communalism. For instance, even though African philosophy scholars agree on the moral supremacy of the community, and communication scholars push for communalistic frameworks capable of adequately addressing these communal relations, there is disagreement on which factors promote the moral supremacy of the community. Gyekye (1997) argues that the individual is morally obligated to the community by virtue 
of the individual's natural community membership; that duties such as respect for community values, sensitivity to the plights of others, and respect for the elderly are accomplished by virtue of the individual's natural membership in the community; and that even though the individual holds certain rights as an independent human being, in the case where those rights clash with community values, the primacy of the community must prevail. For Gyekye such individual rights must "enhance the cultural development and success of the community" (p. 64). Gyekye (2003) also argues that communalism "cannot make a fetish of rights ... priority will not be given to [individual] rights if doing so will stand in the way of attaining a more highly ranked value or a more preferable goal of the community" (p. 308). But whereas Famakinwa (2010) agrees on the moral supremacy of the community and that individuals owe obligations to the community for duties (such as respect for community values, sensitivity to the plights of community members, and respect for old age), he contends that such duties are not accomplished by virtue of the individual's membership to the community. For Famakinwa, belonging to a cultural community does not justify the performance of those duties by the individual; other factors such as poor health of an elderly relative (for respect of old age, for example) might justify why an individual renders the duty, not because she or he is a member of that community.

I am bringing up these conflicting views on the practice of communalism in African cultures to suggest that while communalism is advanced as a paradigm for African communication, and while African philosophers agree that communalism defines 
relations in African cultures, there is need to critically examine the specificities of this framework.

\subsection{Key Concepts of African Communication}

Scholars explaining communication in Africa have suggested a conceptualization of communication that brings the following themes together: indigenization of communicative practices, grassroots participation (e.g., Ansu-Kyeremeh, 1997, 2005), the valorization of indigenous knowledge (e.g., Mogekwu, 2013; Awotiya, 2013; Langmia, 2013), blending or hybridization (e.g., Faniran, 2008), and structural overhauling of communication processes from centrifugal to centripetal (e.g., AnsuKyeremeh, 1997).

\subsubsection{Indigenization}

The concept of indigenization of communication is explained by Ansu Kyeremeh (1997) as the transformation of external or exogenous communication practices into what appears to be uniquely native. The purpose is to valorize native practices such that any

communicative practice (including the use of symbols) that does not reflect native norms is converted into what is customary in native practices. Emphasis is on how external or exogenous experiences are transformed such that they reflect or reproduce local norms, values, traditions, and beliefs systems characterizing the indigenous community.

In its most basic form, indigenization is making something (e.g., idea, approach, or device) to suit the local practices of the community. In contemporary Africa, for example, it is not uncommon to notice how African artists are transforming American 
hip-hop music into native traditional music by giving this brand of music traditional rhythms and even ways of dancing that appears to be unique to the native people. The sounds and rhythms produced that appear uniquely native are achieved using traditional instruments such as nzan, ficaw, nkor, makak, mbem, muyang, egyuk, kwi fon, disam, kala, (Blench, 2009). Mbufong (2013) uses the expressions "Cameroonization" and "nativization" to explain how indigenization has affected the speaking of English. He states that "mixing words, phrases, clauses, and idioms from [local] Cameroonian languages" or "switching from one language identity [French, English] into another Cameroonian language is becoming a means through which Cameroonians express their identity and a 'linguistic belonging' to a geographical location called Cameroon" (p. 476). Such forms of indigenization according to Mbufong also occur for the sake of “convenience" (p. 479). Nsamenang (2013) concurs and insists that "the domesticated patterns of the external cultures have become inescapable components of the African experience" (p. 42).

Ansu-Kyeremeh (2005) sustained his exploration of indigenous communication and maintained,

"Any form of exogenous communicative system, which by virtue of its origin from, and integration into a specific culture, serves as a channel for messages in a way and manner that requires the utilization of the values, symbols, institutions, and ethos of the host culture through its unique qualities and attributes. (pp. 1617) 
He holds that "communication does not occur in a cultural vacuum"; rather, "it is a derivative from the sociocultural context in which it takes place" (p. 19).

\subsubsection{Grassroots Participation}

The emphasis on grassroots participation as a communicative principle and practice in African communication philosophy is on how to address the legacy of colonialist communication structures. This principle as articulated is not about "how people in local communities communicate among themselves to solve local problems but how people at the grassroots level can articulate their views, needs and interests up to the district, regional and national level" (White, 2008, p. 7). Working on a project on development communication launched by the Food and Agricultural Organization (FAO) in Southern Africa, Mefalopulos presents results that suggest participation at all levels by the primary stakeholders was critical for the identification and appropriate implementation of policies to fight poverty. He pointed out the need for an inclusive approach in which "primary stakeholders" initiate, design, implement and evaluate or "at least they would need to be involved in a significant way"; the point is that they cannot be excluded from the process (para. 6). This form of communication is particularly preferred in Africa on grounds that most communities rely on their group actions and organizing to survive (Langmia, 2013; Ansu-Kyeremeh, 1997, 2005). But the concept of participation is more complicated than these simple structures of how communication should flow and the involvement of primary stakeholders.

Grassroots participation as a salient communicative principle and practice must be attentive to issues of power - empowerment, agency, legitimizing marginalized and or 
muted voices (Penderis, 2012). Participation becomes ineffective for the marginalized communities if it is all about corporate entities engaging, consulting, and involving the local people: there is the danger that corporations and state governments may "appropriate" participation by using it as a "manipulative tool" to legitimize their actions and promote their neoliberal agenda (Penderis, 2012). Power relations must be considered if issues of inequality, social justice, empowerment, and grassroots agency are to remain the pillars of effective participation (see Escobar, 2011; Cornwall, 2004; White, 1996).

To ensure that participation is not appropriated, a thorough analysis of power relations in these communities is necessary. By analyzing power relations, we can delineate the "spaces" within which participation occurs and determine the degree or level of agency that emanates from such spaces. ${ }^{1}$ While Cornwall (2004b) explains that these spaces within which participation occurs are permeable and never static, it is important to note that these spaces are venues for power struggles, created for particular motives by different power structures, with specific "terms of engagement" (Penderis, 2012, p. 11). Unless a participatory approach that builds on grassroots agency is enacted, participation remains a "legitimizing device" (Penderis, 2012, p. 3) for corporations and state governments; participation becomes, in short, a way to promote social exclusion. In the communication process, grassroots participants must have agency, be architects, and

\footnotetext{
${ }^{1}$ Participatory spaces have been categorized as institutionalized and non-institutionalized (see Penderis, 2012). Institutionalized spaces are portrayed as 'close', 'well-behaved', 'patronizing', 'summoned', 'invited' and 'provided'. Non-institutionalized spaces or popular spaces are explained to be 'contested', 'claimed', 'captured', 'invented', 'resisted' and 'conquered' sites of interaction (see Aiya, 2010; Escobar, 2011; Gaventa, 2004; Cornwall, 2002a, 2002b).
} 
act proactively, and not reactively if marginalized voices are to be emancipated and legitimized.

Recall the tensions that ensued over community representatives working in the GMOU framework in the Shell case in Niger Delta. Villagers contested the legitimacy of people sent to 'negotiate' with local communities and insisted their own chosen representatives talk with the oil company. In the Herakles Farms case, villagers vehemently contested the role of local leaders and chiefs whom they rejected as speaking for them. These people wanted to speak for themselves through their traditional communal structures and practices, insisting that if any negotiations were to occur, the multinationals should come to their land and talk with them in ways that respected these existing processes.

\subsubsection{Sankofa or Renaissance}

Sankofa is a call for the rejuvenation of what is African yet with a willingness to incorporate what will work within communities. Sankofa emphasizes the need for "finding answers from within" (Ansu-Kyeremeh, 1997, p. 79). In this sense, sankofa could be seen as being complementary to hybrid experiences. The concept originates from the Akan language in Ghana and was coined into communication studies by AnsuKyeremeh (1997). In the Akan tradition, sankofa means "go back and get it": San - to return; $k o$ - to go; $f a$ - to fetch, to seek and take ("Sankofa," 2016). The concept was introduced into African communication studies as an invitation to scholars to return to their African roots and re-ignite traditional African values and knowledge systems in theorizing communication. Sankofa "seeks to achieve the recognition of the capacities 
and attributes of indigenous communication systems as the basis for exploring other forms of communication" (p. 80). Contemporary use of the concept is an invitation for Africans to go back and reclaim their past so they can move forward and also understand why and how they came to be who they are today.

Other interpretations of the concept hold that no matter how far away one travels they must always return home. The basic underpinning of sankofa is that one's past is an important aspect of one's future; that is, in order to make the best of one's future, one must visit one's past. This concept is depicted in the Akan tradition in the symbol of a bird whose head is faced in the opposite direction of its body emphasizing the fact that even though the bird is advancing, it periodically makes it a point to examine or return to its past for a better future (Armwood, 2012). While this principle was found to be salient in a multinational crisis response in these contexts, the principle also risks repeating the silencing of marginalized communities. Scholars should therefore be cautious in how the principle is articulated such that it does not become another occasion for speaking for and about the marginalized.

That said, there is very strong evidence that villagers in the Nigerian and Cameroonian case lay claims on land and oil ownership based on their ancestral past. The past in the two cases was constitutive of the present. The legal instruments regulating ownership of these resources were not sufficient to deter ancestral claims. Thus, the Discourse of Renewal tenet that a prospective rather than a retrospective vision should characterize corporate crisis rhetoric must consider what is meant by prospective and retrospective if understood through sankofa. 


\subsubsection{Hybridity}

While proposing communalism as paradigmatic to communication in Africa, scholars acknowledge the need to hybridize communicative practices in African cultures. Nsamenang (2013) explains the social and cultural situation in Cameroon arguing that the social reality in the country (just like in other parts of contemporary Africa) "is characterized by an uneasy co-existence of endogenous and exogenous value systems and hybrid generation of Cameroonians" (p. 42). The social status quo in Cameroon and Africa in general is seen as being characterized by the "triple existence" (p. 41) of African heritage cultures, Eastern traditions, and Western legacies. Hybridization becomes inescapable for survival within the social and cultural spaces in the continent. The "hybrid generation of Cameroonians" referred to by Nsamenang, is understood in the Cameroonian context to define three groups of people: those who lived through colonialism, those born in the postcolonial era, and those with extensive Western interaction by virtue of their education, career and living experiences abroad. Thus, hybridization is socially and culturally multi-layered and multidimensional, not a simple additive process combining different elements.

It is important to notice that African communication scholars are unanimous that hybridization is an important component for any communication paradigm that aims at effectively addressing complexities and exigencies in African communities. In his call for a return to African communal values to enhance Africa's stagnating development, Oyeshile (2004) suggested the need to "adopt new values and ideas such as will promote future development" in Africa (p. 291). Oyeshile contends that "it is no longer possible to 
maintain cultural isolation" noting that "any attempts to postulate a "unique African personality' involving African ways of knowing, thinking and acting ... would be spurious" (p. 300). For Mogekwu (2013), African indigenous knowledge "adopts from, and adapts to, the world around it" (p. 62). However, while hybridization is another salient communicative principle and practice for the cases analyzed in this dissertation, such calls for hybridity must also be situated within the tensions that characterize differential power relations and ongoing politics of representations. I will have more to say about power and representation in my discussion of hybridization as an element in the amendment proposed in Chapter 7.

\subsubsection{A Shift from Centrifugal to Centripetal Structures}

For communication to be meaningful in African communities, scholars have also suggested a shift from centrifugalism to centripetalism (Wilson, 2008; Tarawelie, 2008; Ansu-Kyeremeh, 1997). It is argued that centrifugal and centripetal structures organize power struggles, with the former seeking to appropriate the source of power, and the latter seeking to decentralize the source of power in communication. In centrifugal communication "power radiates from the center with ripple effect, in centripetal power at the center depends on the collective co-operation of peripheral units" (Ansu-Kyeremeh, 1997, p. 92). These scholars champion centripetal communication flow, if the grassroots are to be part of the power structure for a participatory path towards development in African nations. The focus is a transformation of centrifugal structures of communication. 
Ansu-Kyeremeh sees centrifugal communication as the direct outcome of colonialism in African colonies. He explains that when newly independent nations emerged, the elites who had been trained within the colonial administration inherited and fortified centrifugal communicative practices through the central government structures. For Ansu-Kyeremeh, the centrifugal structure of communication is not only "authoritative" but is also a "unidirectional approach to knowledge transmission" (p. 92) (emphasis in original) which marginalizes community participation and deprives the local people from having a voice in the communication process. In the Shell crisis, the GMOUs exemplify this kind of centrifugal flow that on one hand seems to empower local communities and on the other hand nullifies that empowerment through a paternalistic execution of the agreements.

\subsection{Lessons Learned for Multinational Crisis Communication}

Following are two critical lessons learned for multinational crisis communication in relation to the discussion and case application of salient Afri-centric communicative principles and practices to the Discourse of Renewal.

(1) Multinationals need to reconsider the notion and application of ethical responsibility. The two case analyses indicate that ethics as conceived in the Discourse of Renewal model does not have to be a universal application of the principles of "doing good" for the greater majority of people (utilitarian principle) and being "open" and "honest" during crises (transparency principle). Clearly utilitarianism and transparency are often commendable 
stances but their limitations as universal principles must be acknowledged rather than ignored through claims of moral leadership. The dangers of paternalistic ethos and imperialism under the guise of moral rectitude require vigilance. Ethics must be responsive to the specific geopolitical, moralreligious, and sociohistorical relations wherein the multinational is operating.

(2) There is also the lesson of significant choice articulated in the Discourse of Renewal principally as rationality. This conception of "significant choice" impels the need for organizational leadership to communicate about "what is best for the stakeholders" (p. 217), a requirement to disseminate complete information that allows stakeholders to make rational choices in their decision-making processes. However, the idea that all stakeholders will employ rational criteria in decision-making, that epistemological transparency and completeness can be realized, or that actualizing such ideals is simply a matter of corporate transmission is in itself flawed. In the context of multinational crises in West Africa, the assumptions about western logic and/or rationality do not acknowledge such alternative sensemaking logics as the ancestral claims over land and oil ownership in Nigeria and Cameroon.

(3) Crisis communication by the multinationals addressed contextual issues as problems that locals could resolve (as in the GMOUs), administrative/regulative issues to be managed (as in Herakles' assumption about government permits) or obstacles to be removed (as in Shell/government crackdowns). Yet, my analyses pointed to the complexities 
of indigenous organizing practices, existing interest conflicts such as those among local people, traditional rulers, and wealthy elites, and relations among multiple, often fluid interests including governing authorities, NGOs, tribal groups, even language traditions.

The lessons learned point to the need for a model of renewal that engages with indigenous practices and principles in addressing a crisis affecting subaltern groups. Yet principles of Africentric communication philosophy are abstract. They are ideals rather than working practices. In the following section, I offer reminders of the situational complications that characterize multinational operations in the Sub-Saharan countries. In particular, these complications trouble the ethical mandate at the core of the Discourse of Renewal. Specifically, I consider the prevalence of bribery and corruption as taken-forgranted practices of governance and social life. In engaging such realities, are the moral commitments of a Discourse of Renewal merely forms of imperialism that require denigrating and disciplining Others? Or does complicity with such practices as the "cost of doing business" render such commitments moot? Or do ethical commitments become strategies of manipulation in themselves?

\subsection{5. MNCs and Capitalistic Corruption}

Issues of bribery complicate relations between MNCs, host governments, and local communities because even though bribery is arguably a ritual in governmental structures in both Cameroon and Nigeria, bribery is a nuanced term (in practice) when situated within global relations. According to Lambsdorff (2010), bribery is contextual 
and therefore no universal notion of bribery can capture the concept in a holistic manner. In a study on the perception of bribery tapping 70,000 households in 66 countries (including Nigeria), Lambsdorff noted that a victim's perception of bribery differs from the person who benefits from the act. Lambsdorff's argument that perceptions of bribery might be embedded in specific social relations is an important consideration in understanding what constitutes bribery as an unethical practice. Lambsdorff's research suggested that "bribes are not globally condemned to an equal extent" (p. 18). He argued for moral relativism, urging attention to specific contexts in order to clearly ascertain notions that explain bribery as an unethical phenomenon.

But critics of moral relativism argue that such an approach to ethics/morality "perpetuated the rule of geographical morality by allowing multinational corporations to hide behind 'culture' as the reason for their participation in corrupt business transactions in Africa, Asia and Latin America" (Ala'i, 2000). For these critics, "geographical morality" - a concept introduced by Edmund Burke (See Ala'i, 2000) suggesting the nonuniversal nature of moral principles - needs to be eliminated by "requiring uniform standards of conduct by private and public officials, irrespective of geography" (Ala'i, p. 877). These struggles between the universal/particular binary in conceptions of ethics have not succeeded in dissipating support for geographical morality as the notion continues to inform contemporary anti-corruption movements.

Inconsistencies between laws and morality-in-practice in Cameroon is another relevant complication. The Organization of Economic Cooperation and Development (OECD) whose members are principally developed countries explains a "facilitating 
payment" as not constituting bribery, but rather as "a payment done to speed up an administrative process where the outcome is already pre-determined" (Walters, 2006). According to United States federal legislation, a "facilitating payment" or "grease payment" as defined by the Foreign Corrupt Practices Act amended in 1988, is a payment to a foreign official, political party or party official for 'routine governmental action' such as processing papers, issuing permits, and other actions of an official, in order to expedite performance of duties of non-discretionary nature, i.e., which they are already bound to perform. (Deming, 2005, p. 15). Such payment is explained as "not intended to influence the outcome of the official's action, only its timing" (Deming, 2005, p. 15). Consequently, facilitation payments are exempted from US federal anti-bribery law (Deming, 2005).

But these definitions of "facilitating payments" or "grease payments" as explained by the OECD and US law appear to be incongruous with specific national-cultural contexts. For example, in Cameroon, public officials' approach to routine tasks is often discretionary; and when these tasks are being performed, it is with some form of inertia. Further, public officials more often than not do not feel they owe an obligation to the public when discharging their duties; their allegiance is to the government authority who appointed them to that position. Given such circumstances, defining "facilitating payment" or "grease payment" as bribery becomes more complex. Yet this Cameroonian situation creates difficulties for an American multinational especially in the process of obtaining permits or other licenses to operate in the country, and also when responding to charges of bribery from local stakeholders. What constitutes bribery in the American and 
European contexts appears to conflict with how bribery manifests within social, economic, and political relations in Cameroon. Indeed, local appellations are used in specific Cameroonian contexts by various actors to "water down" the "pejorative meaning attached to bribery" (Fomumdam, 2011, p. 1). These include: "choko", "Kola nut", "myjar", "petrol”, “chokuchoku” (Fomumdam, 2011, p. 1); and I will add "mimbo." Bribery is "informally" accepted in the Cameroonian context.

Even though bribery is an offence punishable by law in Cameroon, Justice Mbah Rose Acha Fomumdam who is currently in charge of the Supreme State Control (a government body whose responsibility is principally to purge the Cameroonian government of corruption) asserts that bribery is almost an accepted norm in the economic, social, and political relations in the country. In a 2016 "most corrupt countries" ranking by the NGO business monitor Transparency International, Cameroon and Nigeria ranked among the countries perceived to be most highly corrupt. Cameroon's corruption perception index is 27 and Nigeria's is 26 so both countries fall within the category of "highly corrupt" zones in the world (Transparency International 2016; also see U.S. Department of State, 2010; Fominyen, 2010). A Reuter's report has described the corruption phenomenon in Cameroon as a "worst-kept secret" (Fominyen, 2010) because although citizens are aware of the phenomenon, and acknowledge it in daily conversation, no one has the courage to take corrupt practitioners to court. The judiciary, penitentiary, the police, business, and all sectors of governmental structures in Cameroon are implicated in this phenomenon. The country's government officials do not see it as strange to accept or push for bribery while performing state functions and public services. 
Not surprisingly, a recent drive to purge the country of corruption has led to the arrest and imprisonment of dozens of persons, many of whom are former government ministers, on charges of embezzlement/misappropriation of public funds.

Nigeria has been described as a powerhouse of corruption. In a recent BBC news report, previous British Prime Minister David Cameron described Nigeria as being "fantastically corrupt" (BBC News; The New York Times). Transparency International noted in its 2016 corruption report that Nigeria has consistently maintained its ranking as one of the most corrupt nations. The report notes that while the fight against corruption is one of current President Muhammadu Buhari's priorities, corruption was "rampant" under the previous administration headed by Goodluck Jonathan. For example, the former petroleum minister of Nigeria is currently seeking refuge in the UK from corruption charges during her term under the former government. The Transparency International 2016 report also notes that "more than US\$157 billion has left the country illicitly" (p. 1); and "corruption hits hardest at the poor in Nigeria who make up more than 40 per cent of the 179 million people" (p. 1). Corruption, the report states, is "everywhere" in Nigeria with all sectors of the government indebted to the phenomenon. Otusanya, Lauwo, and Adeyeye (2012) in their study of multinational companies' anticorruption policies in Nigeria found that MNCs are heavily involved in bribery and money laundering contrary to their mandates for so-called "responsible social conduct" (p. 1). Otusanya, et al., argued that "MNCs have used the political elite in developing countries to seek to advance their global earnings and competitive advantages by offering bribes and other inducements to secure government contracts in Nigeria" (p. 1). 
The point here is that ethical ideals and universal moral principles are not only differently articulated across cultures but that these ideals and principles are unhelpful as operating practices in a crisis communication model. There is need to understand how context affects conceptions and practices of corruption:

(1) Notions of corruption (as in bribery) in some Western contexts appear to be incongruous with notions of bribery in some non-Western contexts.

(2) How corruption manifests itself in relations within some non-Western contexts reframes the ethical, legal, political, and economic implications of such acts and cannot be judged by Western laws or standards.

(3) At the same time, the level of corruption in countries like Cameroon and Nigeria renders social and legal protections for those most affected by MNC exploitation ineffectual without recourse to international courts operating under transnational legal systems.

(4) The impact or offensiveness of the act of bribery attenuates within specific social, economic, and political contexts in Cameroon and Nigeria.

I have described the complications of bribery and corruption at length to demonstrate the need for more responsive strategies of renewal that might engage more effectually in local situations that do not accord with the assumptions underlying the dimensions of the model. A Discourse of Renewal must include not a prescribed ethical stance but reflexivity and vigilance in response to such contextual complexities. 


\section{Summary}

An emerging African communication philosophy offers communicative principles and practices salient to multinational crisis renewal response while at the same time espousing ideals that evoke tensions of their own. The lessons learned are takeaways that inform the amendment I offer. The discussion of capitalistic corruption through the lenses of moral relativity and geographical morality pointed to complex contexts that unsettle the moral rectitude underlying the Discourse of Renewal model. The amendment I offer in the next chapter must be seen as adding to the current Discourse of Renewal so that a responsive approach to crisis communication between multinationals and local communities may be established. 


\section{Discourse of Renewal: Amendments}

\subsection{Introduction}

The lessons learned in the cases analyzed in Chapters 4 and 5 and the discussion of African communication principles and practices in Chapter 6 are important resources for amending the Discourse of Renewal and this is the principal focus of the current chapter. First, I begin with a review of what went wrong in the multinationals' crisis communication approaches taken by Royal Dutch Shell in Nigeria and Herakles Farms in Cameroon.

\subsection{Communication Issues}

Issues emerged based on assumptions about communicative relations and the operationalization of communicative processes in the cases analyzed. These issues point to important power inequities and limitations that inform the proposed amendment.

\subsubsection{Organization as Rhetor}

A major issue that created conflicts in the entire communication process between the companies and local communities was that communication emerged predominantly from the corporate standpoint. The Discourse of Renewal enacted by Shell and Herakles Farms positioned the corporation as the rhetor and defined "renewal" from the corporate perspective. Even though Shell championed transparency, accountability, and open communication with local communities as the backbone of its new community relations, evidence from documents analyzed show the multinational was only transparent in what 
the company wanted the public to know and how the company chose to represent information. For example, information about the volume and impact of oil spills was restricted to what the company decided to share. Amnesty International insisted that Shell manipulated data from an investigation by underestimating the actual volume of oil spills, the duration, and the impact. As such, transparency and accountability, important ethical elements in the Discourse of Renewal, were determined from the corporate standpoint. Further, it was actually the corporation that conceived, designed, and determined how to communicate and eventually implement the Global Memorandum of Understanding. Community relations were largely managed from the corporate standpoint. Even though the company explained that the GMOU arrangement allows local communities to "decide" and "drive" their development, evidence emerged that indicated Shell was at the center of the entire process. The organizational rhetors (company leaders and spokespersons) ensured that the corporate interests and goals of the company were protected. It is possible to see that in this crisis, "renewal" for Shell was to create an enabling environment to do business at any cost.

Similarly, a major problem with the communication approach adopted by Herakles Farms was that the company itself emerged as the primary communicator after the death of the CEO Bruce Wrobel. This entitization of the company meant that all communication was to be conceived, designed, and disseminated by leaders, spokespersons and other decision makers in the organization; this, even as Herakles Farms' Discourse of Renewal claimed the company was engaging in an open relationship with stakeholders. Thus, suspicions about the company's lack of transparency could not 
be resolved. By remaining at the center of communication, a corporate-centric discourse emerged that disregarded communities' norms, practices and modes of organizing.

Additionally, the corporate-centered approach to communication is heavily topdown. This largely affected how stakeholders and the companies' publics perceived, related to, and sought to engage with the organizations. Social justice, stakeholder protection, accountability, and open dialogue were clearly subordinated to corporate interests even in the case of Herakles' part in All for Africa's grand visions for "saving Africa." Further, speaking for the Other was apparent in both cases as corporate representatives articulated community needs and interests for jobs, housing, and education (Herakles) and community development and infrastructure projects (Shell); or denigrated locals as destructive and lawless. This pattern exhibits an implicit sense of superiority/inferiority that warrants ignoring indigenous modes of deliberation and communality. It reproduces the colonialist legacy in the assumption that the corporate rhetor is the only one with something worth saying (or a way of saying it that is worthwhile). The colonialist representation of self vs. the "Other" is characteristic of the rhetor in these complex relations between MNCs and local populations. As postcolonial theory tells us, the Other can only be recognized in these relations (of the colonizer and the colonized) through oppositions of superior/inferior as well as a "diminished" version of the dominant self (cite here-Fanon? Bhaba?). This requires mimicry - in which the Other mimics the representations of the corporation such as going along with the GMoU (in the case in Nigeria) or repeating the promises of Herakles Farms (in the case in Cameroon)(cite here—again, Bhaba?). 


\subsubsection{Communication as Transmission}

Another significant communication issue compromising the Discourse of Renewal is the transmission approach to communication. Here I want to make a distinction between the idea of a transmission model based in the classic Shannon and Weaver frame and transmission as a manipulation within a social construction model of communication. The Discourse of Renewal model itself is premised on a constructionist conception of communication in which the corporate rhetor becomes ethically responsible for disseminating (and enacting) a prospective vision capable of altering the view of reality for stakeholders. However, as evidenced in the case of Shell in Nigeria, communication became a transmission tool prioritizing dissemination of corporate messages while rendering the company's public as passive receivers. In the crises in Nigeria and Cameroon, local communities complained they were not consulted nor engaged in negotiations. Even though both multinationals revised their communication strategies to incorporate what can be recognized as aspects of the Discourse of Renewal, both retained the prerogative of the corporate rhetor to define realities about the enterprise from a corporate perspective as they sought to rebrand and market the new Shell and the revived Herakles as renewed corporations.

\subsubsection{Participatory Communication from Above}

It would be misleading to think that Shell never attempted to engage local stakeholders in its communication process. But the issue is the manner in which the company enacted participation. Communication continues to flow from top to bottom with company officials firmly determining the process. When some half-nude women 
protested against Shell, accusing the company of not implementing the GMoU, in response, a company spokesperson is quoted in a telephone interview saying the company has a channel through which the women should transmit their grievances (Eze, 2014). The implication was that unless the protesting women used the company's existing channels for their grievances, the company would do little or nothing to engage them in dialogue. But perhaps most revealing was that the half-nude (sexuality) protest not only called out the linear, hierarchical structure of Shell's community relations but the paternalistic nature of these relations as well. Shell, it should be recalled, described its new approach to confronting the lingering crisis in the Niger Delta as participatory, with communities deciding and driving their own development while the company serves as funding and capacity building partner. However, local communities protested they are unilaterally clustered into the GMOU framework without consultations. ${ }^{2}$

Communication by Herakles Farms in Phase II of that crisis emphasized that the company was effectively engaging local communities in the palm oil project. As noted earlier, a company executive clearly stated that Herakles Farms "plans to revamp community participation by encouraging small holders to develop individual farms to become an integral part of the palm project" (Mvogo, 2016). The company official also stated that the company would "work with cooperative societies" which are an important economic and social mode of organizing within these communities. Yet cooperative societies in local communities are heavily autonomous community groups whose modes

\footnotetext{
${ }^{2}$ Recall from Chapter 4 that some states were added to the regions' map for "administrative convenience" and "political expediency" (UNDP, 2006; Ibaba, 2005).
} 
of organizing entail dialogue, deliberations, contestations, and eventual agreement by consensus. A top-down communication flow from the corporation to these societies disregards this process. Participation within local cooperative societies does not simply require a show of hands to arrive at decisions. These cooperatives function as community meeting groups and members are bound by community values.

\subsubsection{Renewal}

The last major issue in the communication process adopted by Shell and Herakles Farms revolves around the notion or concept of "renewal" which is a key concept that informs the Discourse of Renewal model. Renewal as described in this model requires organizational leaders and spokespersons to look beyond the crisis and focus on the future by exploiting the opportunities for growth and changes in an organization following a crisis. This requires a prospective and optimistic focus and not a retrospective and strategic focus. Yet even though the Discourse of Renewal encourages organizational leaders to be proactive rather than defensive and reactive, the notion of renewal largely remains corporate-centric.

Unsurprisingly, then, local communities still accuse Shell of applying "divide and rule tactics" in managing the crisis, pitting communities and segments of the population against each other by working with "friendlier" communities and isolating communities perceived to be "hostile" to the company (Amaize, 2012). Local communities accused Shell of creating "antagonism between members of the [Cluster Development Board] and the community development committees" (Amaize, 2012, para 6) by wanting to work instead with members of the development committees in the management of the oil spill 
rather than work with the $\mathrm{CDB}$ as enshrined in the GMoU. The same accusations were made by 300 communities who "accused the oil multinational of using divide and rule tactics against the people" according to Vanguard's July 11, 2016 edition (Amaize, 2016, para 1). The accusation was that the company was "sidetracking" the agency chosen by communities to negotiate. Similar accusations of "divide and rule" tactics have been raised by other communities (see Uwugiaren, 2016; Dugbe, 2014; Onah, 2011; Eze, 2014). My point is that "renewal" was enacted by Shell as a ploy to manage community resistance. Build within a paternalistic framework, Shell's discourse of renewal sustained 'benevolent' relationships that failed to address the logics-in-use in these contexts.

\subsection{Summary Comparison}

The crises analyzed in this study occurred in two different countries and in different economic or industrial sectors. In the Niger Delta region of Nigeria, the crisis was in the extractive industry (crude oil) while in the case in Southwest region of Cameroon, the crisis occurred in the Agro-industry (agricultural sector). The cases differ in terms of duration, violence, MNC size, value of the products, intra- and inter-tribal relations, environmental contamination and destruction, the role of the state, and industry and investor tolerance. However, it is clear that both multinationals struggled against local opposition apart from the intricacies of state corruption and complicity as well as international investment, regulation, and market discipline. In both cases, major points of conflict revolved around ancestral ownership of resources. In the Niger Delta region of Nigeria, local communities laid claims over crude oil and land; in the Southwest region of Cameroon, communities made similar claims over land and forest resources. Other 
major issues raised by local communities in the crises in both cases were on issues of negotiation, participation, disrespect of traditional institutions, marginalization, and exploitation. The multinationals responded to these claims by attempting corrective measures; however, these measures failed to situate the multinationals' efforts within community practices, modes of organizing and sociocultural, economic and even political relations that define the lives of the region's inhabitants.

Crisis communication by the multinationals addressed contextual issues as problems that locals could resolve (as in the GMOUs), administrative/regulative issues to be managed (as in Herakles' assumption about government permits) or obstacles to be removed (as in Shell/government crackdowns). Instead, the analyses pointed to the complexities of indigenous organizing practices, existing interest conflicts such as those among local people, traditional rulers, and wealthy elites, and relations among multiple, often fluid interests including governing authorities, NGOs, tribal groups, even language traditions.

Evidence from the analyses also pointed to important communication issues in the crisis responses of Shell (Nigeria) and Herakles Farms (Cameroon). In both cases, evidence pointed to limitations in the conceptualization of communication inherent to the Discourse of Renewal model of crisis communication. The first is the overarching role of the organization as the rhetor in the communication process. Communication emerged from the corporate standpoint with little attention to local exigencies. The second major problem is the distortion of the social constructionist premises of the model by practices of transmission. Communication in these cases became a tool to transport and 
disseminate information while anticipating an intended impact on an audience arguably perceived to be passive, docile, inferior, and gullible. The third major issue that emerged is the self-serving corporate definition of participation as complicity. Participatory communication was orchestrated from above, that is, under the guidance of the corporations. The fourth significant issue is the conceptualization of "renewal" itself. The Discourse of Renewal model conceptualizes renewal as serving the interests of the corporation even while the impulse may be benevolent. Thus in the case of mulinationals operating in postcolonial arenas, renewal reproduces colonialist legacies that disregard, denigrate, and suppress indigenous alternatives in favor of corporatization and neoliberalism as organizing principles.

Taking into consideration these significant issues, I argue on the basis of the two cases that an adequate model of corporate crisis communication must acknowledge the colonial and neocolonial experiences and residual tensions drawn on the histories of these communities and relevant contexts critical to multinational relations with local communities.

\subsection{Amending the Discourse of Renewal}

The amendment I offer to the Discourse of Renewal advances a concept I call responsive hybridity. This notion of hybridity is informed by African communication philosophy. Adding this tenet (responsive hybridity) to the Discourse of Renewal is intended to make the model more culturally responsive and expands on the ethical component already included in the Discourse of Renewal. Ulmer, Sellnow, and Seeger 
(2011) argue that crisis situations inherently involve ethical issues and dilemmas given that blame, responsibility, fairness, justice, and rights are inherent to such exigencies. Yet they recognize that moral frameworks differ from one group, one corporation, or one culture to another and that there are differing values and definitions framing ethical conduct. Sellnow and Seeger (2016) argue that "Organizations are part of a larger social context and thus should adhere to the larger norms and values that govern that context" (p. 222). At the same time, they advance what appear to be transcultural ethical criteria: --responsibility/blame, significant choice based in transparency, and the open and free flow of information (“open, truthful, honest and immediate," p. 227);

--care for the well-being of others (to "'hear, understand, and be responsive to the subjective voices, experiences, and contexts of community members rather than operate on assumed knowledge of members' (Simola, 2003, p. 358)");

--virtuous conduct by leaders; and

-- adherence to standards of justice, equity, and fairness (with particular regard for the benefit of the least advantaged members of society).

The Discourse of Renewal builds on ethical relationships with stakeholders that Ulmer, Sellnow and Seeger (2011) describe in equally transcultural terms: "Organizations that institute strong, positive value positions with key organizational stakeholders, such as openness, honesty, responsibility, accountability, and trustworthiness, before a crisis happens are best able to create renewal following the 
crisis" (p. 215). The model assumes that corporations have crystallized such core values to guide their decision-making and communication in crisis situations.

Even though they recognize that cultures differ, the Ulmer, et al. Discourse of Renewal model promotes a normative conception of ethics and implies that there are transcultural ethical standards that obligate MNCs. However, there are both differing values and differing definitions of seemingly shared values across cultures, places, histories, and situations. Thus, while corporations and their leaders may design ethical statements and codes of conduct applicable to the corporation's operations and expectations, there is need for a less prescriptive ethical approach in the design and delivery of communication with local stakeholders. Hence, my amendment is for "responsive hybridity" - this suggests that renewal will create hybrid forms, relationships, practices guided by self-reflexivity and ethical vigilance. To be selfreflexive is to pay "careful consideration of the ways in which ['our'] past experiences, points of view, and roles impact ['our' very own] interactions with, and interpretations of, the research scene" (Tracy, 2013, p. 2). That means to be self-reflexive in crisis situations is to be continually sensitive to the ways that personal, organizational, community, or in more general terms, cultural contexts affect perspectives, possibilities, and actions. The ethical vigilance which my amendment summons is conveyed through the African communicative concept of sankofa which I argue, calls for ongoing monitoring of our being and that affects how we relate within the crisis context.

This means that renewal as a creative process of cultural hybridity entails ongoing monitoring of both corporate and community standards and values in order to address the 
inevitable gaps and differences between cultures (geonational, cultural, corporate/community, etc.). For example, definitional differences and conflicts can derail efforts to renew commitments with stakeholders or to recover a positive image. For example, the GMoU in the case of Shell in Nigeria allowed company executives to prescribe to communities what the company perceived as good leadership: "we will continue to engineer development and partner with communities that are well led by notable individuals," a spokesperson for Shell told members of the Romourianwo community during the inauguration of the community town hall (Chinwo, 2013, para. 7). The spokesperson also prescribed the ability for community leaders to "think outside the box" (Chinwo, 2013, para. 3). But these prescriptions and the underlying characterization of what constitutes leadership clashed with communities, and these communities often protested this approach to leadership noting that these so-called community leaders did not represent the aspirations and interests of their communities but the self-interests of these leaders as well as the multinationals.

In another example, the quandary of bribery and corruption as taken-for-granted modes of doing business in both Cameroon and Nigeria is of interest to my argument in support of responsive hybridity. American and European definitions of "facilitating payments" or "grease payments" as propounded by the Organization of Economic Cooperation and Development (OECD) and United States law appear to be incongruous across specific cultural contexts. In Cameroon, public officials' approach to routine tasks is often discretionary; and when these tasks are being performed, it is with some form of inertia. In this context, defining "facilitating payment" or "grease payment" as bribery 
becomes more complex. What constitutes bribery in the American and European contexts appears to conflict with how bribery manifests within social, economic, and political relations in Cameroon.

In both of these examples, a Discourse of Renewal that is amended to include ethical self-reflexivity and vigilance would engage more effectively with local cultures and practices. So, hybridity might mean that MNCs and local communities seek out alternative definitions of what is in crisis; they include local knowledge about the crisis, its causes, and responses; they work through local decision-making structures; they remain open to hybrid projects that reconstruct relationships, infrastructures, and build new opportunities. All of this would be subject to vigilance about ethical issues and dilemmas and responsive to differences in values and moral codes.

My conceptual approach to responsive hybridity draws from a postcolonial theorization critical of the concept of hybridity (Kraidy, 2005, 2002). The underlying theoretical explication of hybridity from Kraidy's argument is that hybridity is never neutral; it carries with it ideologies of particular contexts. Hybridity is a "risky notion" when taken as a simple "association of ideas, concepts, and themes" (Kraidy, 2005, p. vi). The "emptiness" of the concept is even more vivid when given a universal frame that ignores or fails to acknowledge the complexities of situational tensions. This explains why Kraidy argued for the need "to situate every analysis of hybridity in a specific context where the conditions that shape hybridity are addressed" (p. vi). Kraidy's framework of critical transculturalism primarily deconstructs uncritical discourses and conceptions of hybridity which he argues generally promote "ideologies of integration 
and control - not pluralism and empowerment" (p. vii). Thus, for failing to show how issues of power and control play out in processes of hybridity, the concept becomes "strategic rhetoric" that "facilitates a broader negation of power" (pp. vii-viii) and "frames hybridity as natural, commonplace, and desirable in intercultural relations, and therefore noncontentious" (Kraidy, 2005, pp. vii-viii). Further describing an uncritical approach to hybridity as "hegemonic," Kraidy (2002) argued that seeing hybridity as a simple "mixture" in global cultural relations fails to explain the concept as a "communicative practice constitutive of, and constituted by, sociopolitical and economic arrangements" (p. 319); and this blurs the tensions within the contexts in which the concept is applied. Kraidy (2005) maintains that while issues of inequality are not adequately addressed by this simplistic conception of hybridity, "when hybridity is posited as a naturally occurring and globally desirable condition in public discourse, it reproduces the prevailing global order" (p. 152) and in this light becomes the "cultural logic of globalization" (p. 148). This has provided the impetus for corporations including foreign media to use the concept of hybridity as "transcultural wedges" (p. 148) for their activities in local communities.

Frello (2005) also evoked the need to consider contexts and power in hybridity processes in her discussion of what she termed "transgression concepts" (i.e., hybridity, creolization, transculturalization, syncretism) noting that forms of cultural mixture occur in environments "that are always marked by unequal relations of power (p. 5). Frello has argued that hybridity must be seen from a critical dimension "since the celebration of hybridity sometimes works in favor of hiding unequal power relations" (p. 4). There is 
always the need to pay attention to the interests which hybridity serves in public discourses. Frello also evoked the element of context noting,

Hybridity can be articulated in many different ways, depending on the context and on who defines the situation: It can be seen as a threatening contamination of a much valued purity; it can be seen as a creative mixture of disparate cultural elements; it can be seen as a subversive insistence on equality through difference - displacing the 'givenness' of the centered perspective; and it can be seen as yet another strategy for upholding existing power relations. (p. 5)

At one point, hybridity could be seen as erasing binaries in a world in which "we no longer have the secure capacity to draw the line between us and them" (Ang, 2003, p. 141), yet hybridity could be seen as reinforcing these binaries as in "pure" and "impure" cultures. The argument is that if there is never a pure culture, there would be no need for a mixture. In contrast, Jonathan Friedman and Modood (1997; also see Werbner, 1997) think all cultures are always already hybrid.

Silliman (2015) draws from these arguments to insist that hybridity must not just mean "simply mixture nor should it refer simply to cultural encounters in 'zones of difference"" and should not just be another "window dressing" (p. 282) for theoretical frameworks. To reduce hybridity to a synonym of "mixture," "fusion," or "intercultural encounters" (p. 282) neutralizes the interpretation of these encounters which hybridity must be able to "unpack" (p. 283). As such there is the risk for binaries to emerge, as well as the danger 
of marginalizing rather than empowering disempowered communities when hybridization occurs within the framework of simplistic mixtures or fusion (Silliman, 2015).

Discussing the multinational corporation as a hybrid space, Frenkel (2008) has noted that "the transfer of management knowledge and practice within the MNC is increasingly a matter of relations between dominating and dominated societies" (p. 925). Thus, hybridization does not often occur on a "level ground of equality" even as some scholars see it this way (Smith, 2004, in Frenkel, 2008, p. 927). The conception of hybridity in the proposed amendment is sensitive to these issues of power and difference. In the following section, I discuss how responsive hybridity might affect the existing dimensions of the Discourse of Renewal model.

\subsection{Reframing the Discourse of Renewal}

\subsubsection{Ethical Leadership}

Beyond the fact that leadership in the crisis renewal model is heavily individualistic and paternalistic as seen in the role of the corporate rhetor, there is also the neocolonialist assumption of white men and capital saving Africa. This is clearly illustrated in Chapter 5 in discussions of Herakles' CEO Bruce Wrobel's narrative about his company's investments in Cameroon and Africa. Because neoliberalism expands opportunities for profitable capital accumulation (Harvey, 2006; El-Ojeili \& Hayden, 2006) multinationals tend to avoid forms of inclusivity that appear to constrain this open market and profiteering approach to management. As the analysis of Shell's GMoUs in Nigeria suggests, communities dependent on or subject to the operations of 
multinationals are only marginally included with little or no power to affect the parameters of their relationships. This calls for a more radical approach to the notion of inclusivity.

Mumby's (2013) critical communication perspective of leadership not only points to disempowering approaches in communication, but argues that leadership should be thought of as a "socially constructed phenomenon" (p. 256), noting that social, economic, and political conditions interact to frame our perceptions of what leadership entails. Mumby warns against the framing of "leadership" by "a discourse" emerging from centers of power, and calls for the need to problematize what we think we understand to be "leadership" by exploring the concept of leadership as "complex, ambiguous, and uncertain" (p. 257). The critical communicative perspective offers a different view on leadership by disrupting the commonplace organization-centric explication of leadership.

In Mumby's words, leadership is clearly “coproduced among organizational members"; and emphasizes the notion that "leadership is [a]socially constructed process in which social actors interdependently create what leadership means in specific organizational contexts" (Mumby, 2013, p. 270; see Fairhurst, 2007; Fairhurst \& Grant, 2010). Communication is "central to the ways leadership is socially constructed." By analyzing talk or texts, for example, it is possible to see how leadership is socially constructed. The critical communication perspective "decenters" the "great man" as leader. Instead, leadership is seen as being distributed throughout the organization and occurring through interactions. Another major focus of the critical communication 
perspective sees leadership as entangled with issues of power and control (see Zoller \& Fairhurst, 2007; Conrad \& Poole, 2012).

There is evidence that supports this idea from the data analyzed in this study. In both the Nigerian and Cameroonian cases, oppositional struggles between local communities and the companies exposed the disjuncture created by a community perspective of leadership and what the companies constructed leadership to be. For the companies, leadership is more about the organization - achieving efficiency and attaining organizational goals. This placed the multinationals in disparate power relations with the multinationals operating from a paternalistic standpoint; that is, organizational leaders determined action as in a father-child-relationship. The GMoU in the case of Nigeria allowed company executives to prescribe to communities what the company perceived as good leadership: "we will continue to engineer development and partner with communities that are well led by notable individuals," a spokesperson for Shell told members of the Romourianwo community during the inauguration of the community town hall (Chinwo, 2013, para. 7). The spokesperson also prescribed the ability for community leaders to "think outside the box" (Chinwo, 2013, para. 3). But these prescriptions and the underlying characterization of what constitutes leadership clashed with communities, and these communities often protested this approach to leadership noting that these so-called community leaders did not represent the aspirations and interests of their communities but the self-interests of these leaders as well as the multinationals. 
African communication philosophy points to the need for inclusivity in communication practices. White (2008) for instance noted that participation in communicative action should be about "how people in local communities communicate among themselves to solve local problems [and] how people at the grassroots level can articulate their views, needs and interests up to the district, regional and national level" (p. 7). Mefalopulos (2003) from a similar perspective insisted on a participatory approach in which "primary stakeholders" are able to initiate, design, implement and evaluate or "at least they would need to be involved in a significant way" (para. 6). Even these conceptualizations of participation or inclusivity appear to be too simplistic and fragile for marginalized communities in their relations with multinationals. In fact, this is the same form of participation which the leaders of Royal Dutch Shell touted in their GMoU with Niger Delta communities. Shell claimed communities conceive, design and implement their development projects while the company provides funding. But the relationship is such that communities rely on the benevolence of the company to secure funding for their projects. The "divide and rule" tactic which many communities decried in their relations with the company was partly the result of the perception that Shell was working with communities that aligned with the terms and values set down by the company while neglecting those that did not fully collaborate with the company (Amaize, 2016; Uwugiaren, 2016; Amaize, 2012). This form of participation constrains community empowerment and continually mutes already muted voices - e.g., muted histories.

In the Niger Delta case, issues of the appropriation of the negotiation process by Shell (Amaize, 2011; James, 2015), poor community representation (Uwugiaren, 2016; 
BBC Monitoring Africa, 2012; Oyadongha, 2016), and even the clustering of communities into Community Development Boards are examples of how a corporate paternalistic approach to participation impacts marginalized communities (see Amaize, 2011; James, 2015). Royal Dutch Shell exerted a lot of power in its community relations. Some communities accused the multinational of unilaterally deciding to "dissolve the board [a $\mathrm{CDB}$ ] against the provisions of the Global Memorandum of Understanding entered into by both parties" (Amaize, 2013). Other aspects in the Nigerian case that point to the need for a more critical conceptualization of participation include the accusations against the multinational concerning issues of selectively implementing or defaulting on the implementation of signed agreements with communities (BBC Monitoring Africa, 2012; James, 2015), and accusations of abandoned projects (Onoyume, 2013). Such inequitable power relations should be considered if issues of inequality, social justice, empowerment, and grassroots agency are to remain the pillars of effective participation (see Escobar, 2011; Cornwall, 2004; White, 1996). Reframed by responsive hybridity, the element of inclusivity ascribes to possibilities of responsive empowerment - communal empowering, communal agency, legitimizing marginalized and or muted voices - which as Penderis (2012) has argued cannot be neglected if the grassroots must become architects in the participatory process. This conceptualization of inclusivity challenges a simplistic approach to participation in which multinationals use participation as a "legitimizing device" (Penderis, 2012, p. 3). Participation for these companies thus becomes a means to portray the company as being socially responsible in order to fully establish its operations in these communities. 


\subsubsection{Prospective versus Retrospective Vision}

The Discourse of Renewal theorizes the importance of a prospective vision and cautions against a retrospective vision. That is, organizational leaders should focus on the future and avoid issues of blame which often is the result of looking into the past following with the intention to deny or scapegoat. Reframed through responsive hybridity, this component of the model entails a more collective vision and the need for respecting the role of the past - that is the past as constitutive of the present. The past constitutive of the present is also informed by the concept of 'sankofa' - a way of being that is responsive to your roots. Evidence from the crises in Nigeria and Cameroon suggests that in the existing Discourse of Renewal, "prospective vision" is largely flawed given the model's inability to theorize the present. The communities' claims over ownership of land and crude oil in the two cases analyzed clearly summoned the present. Further, these claims were based on communities' attachment to their ancestral past. In the Niger Delta, communities claimed the oil belongs to them because it was produced on land they claimed was owned by their ancestors and passed down to the current generation. Similarly, the claims of land ownership and accusations of land grabs against Herakles Farms emerged from the history of communities' reverence for their ancestral past as well as long-held practices of subsistence agriculture and resource use. In both cases, there is a reverence of the past that conditions the present and the future. Communication must be able to address this complexity of time. 


\subsubsection{Organizational Learning}

While the Discourse of Renewal holds that it is important to communicate and implement organizational learning following a crisis, I argue that learning cannot happen outside the contexts of organizational action and change. So, the power dynamics of a postcolonial encounter have to be engaged. Learning should not simply be the organization implementing and communicating lessons learned from the crisis to stakeholders (whether these lessons be mandated by regulatory agencies or simply implemented proactively by the organization). There is another kind of learning that is just as critical: the need for MNCs to move beyond the dominance/subjugation dynamics of the MNC/African encounter. MNCs must learn to reject the inherent sense of superiority that warrants ignoring indigenous modes of deliberation and communality treating these modes/practices as inferior or less worthy in these encounters.

Multinationals mustbe willing to learn from local norms and locally lived experiences. But the relationships that define the learning process must not be superior/inferior learning must occur in relations of equity, not paternalism. The outcome of such learning processes can become culturally responsive.

\subsubsection{Ethics}

Much has already been discussed about ethics but the focus at this point is to show how ethical applications must be responsive rather than prescriptive. I do this by looking at the aspect of Corporate Social Responsibility (CSR).

CSR is relevant to my amendment to the Discourse of Renewal because this model entails an ethical component that expands on the idea of "social responsibility" 
beyond the profit motive. While MNCs are profit-making endeavors, both the Discourse of Renewal and CSR are conceptions of corporations as subject to obligations beyond those imposed legally or through the market. CSR need not be counter to the profit motive; indeed, Hilson (2012) observes that it is generally accepted that "there are incentives for business to proactively embrace environmental and community development concerns" (p. 132). However, many multinationals take advantage of CSR activities to promote their profit-agenda, considering CSR to be good business strategy, not necessarily an obligation which the multinational must undertake. Multinationals' CSR activities are not "goodwill" but carried out in order to ensure smooth operations within communities. As such, for multinationals, CSR is "good business" and "good for business." Both CSR as a business strategy and the corruption of CSR for profits have particular ramifications for MNCs in developing countries. I turn first to a discussion of the profit incentive for CSR and then to the case of CSR by MNCs in the developing world.

According to Knox and Maklan (2004), five incentives drive CSR: (1) consumer preferences will increasingly favor products and services from socially responsible, transparent and trustworthy firms; (2) investors will increasingly favor responsible companies and irresponsible companies will find their cost of borrowing rises; (3) potential employees will be attracted to more responsible companies; (4) engaging with stakeholders encourages innovation; and (5) being trusted by stakeholders and pursuing socially responsible policies reduces risks arising from safety issues, potential boycotts and deteriorated corporate reputation (p. 506). Yet apart from these incentives, CSR 
properly managed is not solely about marketing or profit but must become integral to corporate policies and practices. Cash (2012) indicates that there has been a failure on the part of many MNCs to "integrate social responsibility policies within company frameworks ... [for] corporate accountability" (p. 132). Perceptions even become bleaker if the notions of avoiding regulation are evoked in this discussion of MNCs' corporate social responsibilities.

El-Ojeili and Hayden (2006) indicate that MNCs show very little social responsibility in the less developed world. While the presence of MNCs in Sub-Saharan Africa - and the African continent in general - was integral to the colonial governments in Africa, MNCs' influence became a dominant force in Africa in the 1970s when neoliberalists advanced the open-market doctrine. To gain easy access into African economies, MNCs used, among other strategies, promises of services and infrastructure provision and by the 1980s, the "obvious financial benefits" of CSR provoked a profitdriven agenda (Hilson, 2012, p. 132). The "development agendas" of MNCs portrayed corporate social responsibility as being significant to economic and social growth of African nations where there were huge potentials in the extractive industries especially in countries like Nigeria and Angola, and for agricultural products including cocoa, banana, and palm plantations in Cameroon and the Ivory Coast. Fonjong (2014), for example, points to the optimism that galvanized large-scale land acquisition in Cameroon following promises made by multinationals to create employment on and off farms, pay royalties and taxes, improve rural infrastructure including road, water, health posts, schools, and access to technologies. Yet without explicitly incorporating CSR into their 
policies and frameworks that govern their operations in overseas territories - such that CSR becomes a corporate obligation (see Cash, 2011) - CSR remains solely and cynically a marketing and profit strategy. MNCs tie their CSR to corporate benefits that will accrue as a result of undertaking such social responsibility.

At the same time, incorporating CSR as a market ploy into corporate structures and policies is not only unethical but damaging to communities and environments. For example, Hönke and Thauer (2014) criticize MNCs in South Africa for "commercial priorities" that limit CSR to the immediate vicinity where corporate operations are located, resulting in an "unequal distribution of collective goods" (p. 711). In SubSaharan Africa, MNCs have resisted "proactive CSR" (Ackah-Baidoo, 2012) as they failed to invest socially, environmentally, and economically in communities other than what is required by law or regulation. As Chapters 4 and 5 indicated, the lack of socially responsible operations can have devastating consequences. For example, in the case of the Niger Delta, local communities have seen the "economic exploitation of the region's vast crude oil reserves by multinationals ... and the specter of environmental devastation, excruciating poverty, and recurrent rule of impunity" (Orogun, 2010, p. 460). Thus, Hilson (2012) argues that crediting MNCs with CSR in developing nations - where for decades they have been involved, for instance, in the extractive industry, in shipping billions of tons of crude oil to markets across the Atlantic Ocean, polluting communities, grabbing lands, and engaging in corruption-is nothing but a "delusional assessment" (p. 132). Thus, there is need for a critical assessment of CSR by MNCs in developing countries. 
Clearly, this discussion of MNCs' distorted CSR is intended to show how complicated it is to want to use the current Discourse of Renewal to address crises involving MNCs entangled in differential relational complications. All components of the current model might contribute to the rhetoric of an MNC intent on protecting their profit-driven agenda. For example, a prospective vision might be geared to the need to protect corporate profits leaving key community concerns unaddressed. Organizational leaders might reframe reality during a crisis to favor corporate intentions. Using effective organizational rhetoric could mean the organization manipulating communities by minimizing issues that could affect corporate profits. In addition, the ability for organizations to "learn" from a crisis vis-à-vis local communities is not certain, after all, MNCs are in stronger power positions in their relations with local communities. For example, in discussing organizational learning as a component in the current Discourse of Renewal, Ulmer et al., mentioned three kinds of learning (systemic, paradigmatic, and behavioral) and suggested that organizations should aim for systemic learning - that is, organizations should show evidence of proactively or preemptively avoiding the reoccurrence of a crisis. I argue that with little or at least very weak obligation on the part of MNCs to justify their actions in relations with local communities, and with a focus on profits, this component could be problematic in the manner in which "learning" has been enacted in the current Discourse of Renewal.

A more critical sense of Corporate Social Responsibility in the contexts of the Discourse of Renewal's application to the cases analyzed is that CSR is in collusion with the Renewal model; both emerging from a corporate-centric standpoint and relating to 
local communities in strongly paternalistic ways that repeat the silencing of these communities. Reframed by the responsive hybridity amendment, the ethics of CSR must be responsive to the contexts within which the corporation operates in the world. The Herakles Farms crisis in Cameroon and the oppositional struggles Shell faced in the Niger Delta of Nigeria could well be examined from the point of view of these companies' failure to ethically situate their operations in terms of communal ethicalness. In Cameroon, Herakles Farms was perceived not to be interested in enhancing harmony and the overall good of these communities. Besides, signing the establishment convention with the government of Cameroon was not enough reason for communities to accept the Herakles Farms' operations, partly because the establishment convention failed to consider a historical past that the people remained attached to in the claims they made. Similarly, in the Niger Delta of Nigeria, oil spills (delayed cleanups), gas flaring, and the death of community activist Ken Saro Wiwa all contributed to exacerbating Shell community relations and these are not incidents that show Shell cared for the community. A communal approach to ethics goes beyond communicating a company's intentions or desires to be honest, transparent, and accountable - even if the company is perceived to be conforming to these ethical principles (which was not necessarily the case in Nigeria and Cameroon). 
Table 5. Amended model: Responsive Hybridity as addition

\begin{tabular}{|l|l|l|l|l|}
\hline Dimension 1 & Dimension 2 & Dimension 3 & Dimension 4 & $\begin{array}{l}\text { Dimension } \\
5\end{array}$ \\
\hline $\begin{array}{l}\text { Ethical } \\
\text { Communication }\end{array}$ & $\begin{array}{l}\text { Prospective } \\
\text { vs. } \\
\text { Retrospective } \\
\text { Vision }\end{array}$ & $\begin{array}{l}\text { Effective } \\
\text { Organizational } \\
\text { Rhetoric }\end{array}$ & $\begin{array}{l}\text { Organizational } \\
\text { Learning }\end{array}$ & $\begin{array}{l}\text { Responsive } \\
\text { Hybridity }\end{array}$ \\
\hline
\end{tabular}

\subsection{Implications for Current Crisis Renewal Model}

The two cases analyzed in this dissertation allow me to delineate some implications on the Discourse of Renewal, Multinational Communication, and crisis communication scholarship and practice.

The first implication is that the focus on "renewal" in this model may be too optimistic as a strategy of crisis response. There are crisis conditions that are simply beyond an optimistic focus--or beyond corporate crisis rhetoric in general-whether renewal or apologia. For example, in the case of Nigeria, decades of impoverishment of the people of the Niger Delta region, decades of corruption and environmental destruction, and the spiraling of intra- and inter-tribal conflicts in this region are truly conditions that cannot be addressed mainly through corporate crisis rhetoric. In addition, Shell's perceived complicity in the violence that has literally gotten out of hand in the Niger Delta region - militant groups competing with each other - as well as the company's disregard of suffering masses renders a Renewal Discourse quite insufficient.

The second implication is that if non-crisis conditions are such that ethical practice and Corporate Social Responsibility cannot operate without distortion and 
corruption, crisis communication responses become inadequate. The cases in Cameroon and Nigeria indicated that corruption has seemingly been normalized even though there are legal instruments regulating corrupt practices. When non-crisis conditions are such that ethical practice cannot thrive during crises, a corporate discourse in this regard becomes insufficient. The Herakles' case in Cameroon indicated how the multinational bribed government officials as well as tribal chiefs to have their operations established in the country negating effective participatory governance as well.

The third implication is that if multinationals cannot be held accountable by African governments, the power of the multinational will remain unchecked during crises - hence these multinationals will have little "obligation" to address the situation. Amnesty International (2017) noted that "Shell's US law firm is refusing to hand over more than 100,000 internal documents crucial to a legal case in the Netherlands which is alleging the oil giant's complicity in the unlawful arrest, detention and execution of nine men in Nigeria in the 1990s" (para. 1). This is the case concerning the "Ogoni 9" murdered by the military regime among whom was Ken Saro Wiwa. The widow to Wiwa was among those who filed the case in Netherlands after 20 years of fruitless legal battle in Nigeria.

This chapter has detailed the responsive hybridity amendment to the Crisis Renewal Model and discussed the way all dimensions of the model are affected by this amendment. In chapter 8 I return to the research questions that motivated the dissertation to summarize my findings and arguments. I also discuss limitations of this research and directions for future research. 


\section{Conclusion}

\subsection{Summary}

Chapters 6 and 7 addressed the research questions that motivated the case analyses and the amendments in this dissertation. I begin this chapter by summarizing the findings in response to the research questions. The research questions are as follows:

RQ1: What are the limitations of the Crisis Renewal model for multinationals operating in West African countries?

RQ2: How can this model be amended based on African communication principles?

\subsubsection{Summarizing Research Questions}

RQ1: My analyses indicated several limitations to the renewal model applied to crises faced by multinationals operating in West Africa. The failure of companies to recognize the complexities of the crises they faced or to respond ethically to the consequences of corporate exploitation as well as the resistance of local communities in Nigeria and Cameroon indicated that the renewal model fails to adequately engage the agency of marginalized stakeholders. Local norms, exigencies, and the complex relationships that are part and parcel of communities' lived experiences cannot be disregarded by multinationals as they craft a crisis response. While an amended renewal model cannot fix the corruption, politics, and the complex relationships between the multinationals and local communities in Nigeria and Cameroon, the purpose has been to rethink the concept of "renewal." 
The lessons learned indicated that there is need for a reframing of the conception of "renewal" in order to go beyond renewed ties between stakeholders and the corporate rhetor (as the model suggests). Rather, this dissertation argues for "renewal" as an emergent and ethically vigilant hybridization of local and multinational organizing practices rather than a corporate-centric paternalistic approach. This means that renewal as a creative process of cultural hybridity entails ongoing monitoring of both corporate and community standards and values in order to address the inevitable gaps and differences between multinationals' and communities' ways of organizing. In addition, renewal entails a co-constructed version of the realities of the present and the presence of the past. Rather than guilt and blame, the presence of the past involves respect for traditions and histories and an acknowledgment of corporate and community differences in values, knowledges, and realities. A responsive hybridity remains vigilant in the acknowledgment that extant inequities deny the subaltern the power of self-representation and that entrenched inequities and self-disciplining forces undermine corporate ethics.

Amending the renewal model with responsive hybridity has ramifications for all of the dimensions of the Discourse of Renewal.

(1) Prospective versus retrospective vision: Data analyzed indicated that organizational leaders cannot focus on moving forward, and remaining optimistic about the future (prospective vision) thereby not focusing on issues of blame (retrospective vision) and be responsive to the in situ communicative demands of a non-Western crisis context. In the Nigerian and Cameroonian cases, the theme of ancestral land rights and oil ownership pointed to the fact that communication 
must be able to address non-rational decisional criteria. The ancestral claims made by local people also entail sankofa or the renewal of past in present and this as well refigures the conception of retrospective vision beyond concerns over corporate reputation and relationships.

(2) Organizational learning: In applying this component of the Crisis Renewal Model, MNCs must learn to beat the inherent sense of superiority that warrants ignoring indigenous modes of deliberation and communality - treating these modes/practices as inferior or less worthy in these encounters. Organizational learning must be responsive to local norms and locally lived experiences. More importantly, the relationships that define the learning process must not be superior/inferior; learning must occur in relations of equity not paternalistic dependencies.

(3) Ethical leadership: When applying the renewal model, MNCs must be cautious about relying on titular leadership as a sufficient proxy for local communities. In addition, MNCs must be vigilant against reinscribing neocolonialist and neoliberal assumptions of white men and capital saving Africa. For example, in the Nigerian case, Shell's GMoUs allowed company executives to prescribe to communities what the company perceived as good leadership: "We will continue to engineer development and partner with communities that are well led by notable individuals," a spokesperson for Shell told members of Romourianwo community during the inauguration of the community town hall (Chinwo, 2013, para. 7). Communities often protested this approach to leadership noting that 
these so-called community leaders did not represent the aspirations and interests of their communities but the self-interests of these leaders as well as the multinationals.

(4) Effective organizational rhetoric: Ethical communication must be responsive rather than prescriptive. As discussed earlier in Chapters 2 and 7, the model's concept of "significant choice" is important, mandating both beneficence and transparency. That is, organizational leaders and spokespeople are exhorted to construct realities that are not skewed by corporate interests alone and to provide all necessary available information to stakeholders so they can make independent decisions. Yet there are such complicated extenuating circumstances in any crisis situation but particularly those involving deeply entrenched power differentials and alternative epistemological frames that these mandates are rendered implacable. This dissertation suggests that ethical communication must be focused on bettering communities rather than on bettering corporate stakeholder relationships and must be responsive to the intricate complications of histories, knowledges, ethics, and power enacted in local contexts in order to do so. This therefore, means, locally lived experiences and perspectives should be empowered in constructing realities during and following a crisis. 
RQ2: How can this model be amended based on African communication principles?

Having analyzed the Nigerian and Cameroonian cases, evidence emerged that showed the following are important African communication concepts with critical implications for enacting the renewal model in a multinational crisis response.

\section{(1) Sankofa}

This concept emphasizes the importance of how the present and the future are influenced by looking back in order to be conscious of who we are, where we come from, what our roots are. In the cases in Nigeria and Cameroon, the ancestral claims over land and oil could be interpreted as a function of the concept of sankofa. A multinational Discourse of Renewal must be responsive to differing cultural significances in relations among past, present, and future and find ways of integrating this into its renewal discourse.

\section{(2) Indigenization}

In its most basic understanding, this means transforming something, e.g., communication, an idea, or an approach to suit the local practices of communities. A renewal discourse (as seen through the GMOU in Nigeria) should be responsive to communities' practices and norms. While this may seem obvious, the discussion of corruption and bribery as indigenous practices suggests the complications that MNCs must address in global operations. 
(3) Hybridity

I have argued against a commonplace conception of hybridity as simply the melding or combination of endoganous and exoganous elememts. In addition, I have warned against an instrumental conception of hybridity that lends itself to corporate strategic rhetoric. Instead, I have argued for hybridity as a "transgressive" concept that compels responsiveness to inherent power inequities, implicit binaries, and superficial relations. By responsiveness, I mean both self-reflexivity and a deconstructive stance toward takenfor-granted meanings, relations, and practices in encounters between MNCs and local communities. I have argued that renewal can involve creating hybrid forms by seeking out alternative definitions of what is in crisis; including local knowledge about the crisis, its causes, and responses; working through local decision-making structures; and taking a risk on new relationships, infrastructures, and opportunities emerging from hybridization.

\subsection{Reflections}

In this section, I reflect on the limitations and future directions of my research. Perhaps more importantly, I discuss what I consider a critical argument for praxis in crisis communication.

\subsubsection{Limitations}

In part, the limitations of this research are inherent to the conventional methodology of crisis communication studies, that is, the use of publicly available data and case studies. I address each of these in turn. First, second-order data from newspapers, radio texts, and NGO reports can be considered a limitation of this research. 
These are, of course, not neutral sources. From my journalism background, I am aware that personal, organizational, political, economic, and market forces (e.g., advertising money) can have a huge impact on how stories get reported. At the same time, such publicly available texts clearly shape the meanings and trajectories of crisis situations as well as the lives and possibilities of those affected.

The use of case studies is a limitation in crisis communication research that has been acknowledged (Coombs). The specificities of a case study make this approach useful in understanding the complexities of crisis situations. At the same time, this very advantage makes generalizing from case studies difficult. Yin $(2009,2004)$ has argued that the potential to generalize research results using a case study approach is a rigorous process since the purpose in a case analysis is not always to generalize results to an entire population, but rather to theoretical propositions. However, and as Yin agrees, while multiple case analyses are appropriate for replicating results, a single case that critically challenges existing theoretical frameworks is sufficient for generalizing research findings. Nonetheless, I am sensitive to the limits of case analysis in forwarding an amendment to the renewal model.

\subsubsection{Proactive Renewal Studies as Engaged Scholarship}

A troubling limitation in the crisis communication literature that has become apparent to me is that while the renewal model advances a positive communication approach for recreating mutually beneficial stakeholder relationships, there remains a lack of critical reflection and engaged scholarship aimed at transforming oppressive conditions. I recognize that proposing an engaged role changes the nature of crisis 
communication research by foregrounding a critical political commitment that I argue is implicit in the proactive renewal model.

This dissertation set out to offer an amendment to the Crisis Renewal Model of crisis communication developed by Ulmer, et al. (2007). While there are other crisis communication models, this Renewal model was chosen specifically because of its proactive approach to crisis response, an approach that avoids reducing crisis communication to an image/reputation management practice. But even with this promise to avoid making reputation its central focus, the model remains tied to a classical rhetorical tradition that values the role of the corporate rhetor and the ethics of corporate leadership and falls short for not providing a global purview to the central tenets that constitute the model. My amendment, the outcome of lessons learned from cases analyzed on multinational corporate crises in Nigeria and Cameroon and informed by a review of African communication principles and concepts, sought a more complex conceptualization of the rhetorical strategies that comprise the model. The dissertation argues for renewal as an emergent and ethically vigilant hybridization of local and multinational organizing practices. Ethical vigilance is a call to be responsive to the logics-in-use in different contexts, and to engage in a constant monitoring of corporate/local stakeholder assumptions, meanings, practices, and power relations within crisis contexts. This emergent and ethically vigilant hybridization of local and multinational organizing practices and perspectives is supported by African communicative concepts including indigenization, hybridity, and sankofa. 
In doing this research I have come to realize a larger responsibility for scholars in this area. I realized that in crisis communication studies, it is not imperative for scholars to take a more critical and engaged role. Yet in cases of MNCs operating in the African continent, blending the activist and scholarly role may be more ethically imperative. I am in concurrence with observations by Manuh (2007) who pointed out:

I think that in Ghana and the Third World generally, researchers do not have the luxury to cleanly demarcate the separations [between activism and research]. If the person is genuinely concerned about justice and change then s/he will, whether activist or researcher, merge the two...Also because Third World intellectuals are still very much free to confront and struggle for all kinds of democratic and political changes, they/we are compelled to act. (p. 138).

In other words, the role of a public intellectual is significant in these contexts. In order to realize this role, the amendment I have developed must be refigured as an invitation to engaged scholarship. While conventional crisis communication scholarship is posed as case-driven and adopts the distanced stance of the researcher examining post hoc crisis data, engaged scholarship seeks to develop collaborative relationships with stakeholders in a crisis case in order to develop co-constructed understandings and promote transformations in oppressive conditions and relationships.

Putnam and Dempsey define engaged scholarship as "research that highlights practical problems, develops reflexive bridge between scholars and practitioners, and co- 
develops knowledge among stakeholders" (2015, p. 11). They identify five "faces" of applied scholarship: applied communication research; collaborative learning; activism and social justice; practical theory; and public scholarship (p. 13). Of these, my amendment to the Discourse of Renewal might most readily facilitate an applied communication research approach involving adapting principles of the renewal model modified by responsive hybridity to address community-identified problems and interventions that mediate corporate interests and community needs. However, I am drawn to the face of practical theory focused "on three activities: mapping, engaged reflection, and transformative practice" (p. 16). Adopting this approach would require refiguring the crisis case approach "as generative and as working reflexively with the tensions between theory and practice" (p. 16).

In such a refiguring, the engaged activity of mapping might entail in situ dialogue as a mode of data collection and organizing the detailed descriptions of a case around the practical implications of struggle against oppressive conditions. The activity of engaged reflection can be addressed by my argument for self-reflexivity and ethical vigilance as components of responsive hybridity. As engaged scholarship, such reflexivity would be part of a collaborative scholarly inquiry into the contradictions between corporate and community "norms or standards for evaluating practice" in a crisis situation. The goal is to eschew "a normative logic of technical moves designed to address problems" in favor of a grounded practice of responsive hybridity. Finally, the third engaged activity of transformative practice would take the renewal model as a mode of transformation 
bridging theory and practice together in the particular situation in order to "transform experiences through co-producing knowledge in conversations with practitioners" (p. 16).

While I have posed the lack of a practical scholarship orientation as a limitation, it is also a direction for future research and one that I am determined to explore. There are other trajectories that would contribute to the development of an amended model of renewal as well.

\subsection{Future research}

Future research is need to develop both the amendment I have proposed and its implications for the renewal model. I suggest activities such as conducting additional case studies and developing ethnographic studies of crisis renewal and responsive hybridity.

First, additional case studies should be conducted in order to enhance the value of the amendment and to consider its modifications in other situations. For example, there are certainly more $\mathrm{MNC}$ crises in Africa that would provide opportunities for further application of the amended model. Such cases might include the sweet potato project in Senegal by an Italian company, land rights crises in Ghana (Babator, Okumaning, and Brewaniase communities). Another important direction for future research is to apply the amended crisis renewal model to non-Western MNCs. While both of the corporations I studied were based in Western countries, there are Chinese MNCs operating on the African continent whose operations would provide an alternative context for considering crisis renewal. 
In this vein, another direction for future research would involve considering the appropriateness of the African communication concepts I have based my amendment on in corporate crises affecting marginalized populations beyond the African continent. For example, the recent stand-offs by Native American tribes against the Transcontinental Pipeline from Canada offers a case that might stretch such Afri-centric concepts as sankofa. At the same time, responsive hybridity is meant to offer possibilities for in situ adaptations. Hence, applying it to cases in which relationships between corporations and marginalized populations raise Spivak's question of "Can the subaltern speak?" seem critical.

A second direction for future research is to refocus corporate renewal by conducting ethnographic studies and qualitative interviews. Here again there are implications of this suggestion that do not accord with the conventions of crisis communication research. Specifically, the foregrounding of corporate reputation, leadership, and rhetoric would be displaced. Instead, doing ethnographic work would emphasize the lived experiences of corporate crises, both for those in the corporation and those in affected stakeholder groups. There is an extant literature detailing such cases; for example, the many studies of stakeholder experiences and the reputational crisis of the Federal Emergency Management Agency (FEMA) following Hurricane Katrina and Hurricane Sandy in the US. However, an ethnographic approach would have particular value in the crisis cases I have examined in this dissertation. For example, the lived struggle among those in the Cameroon forest who find their ways of life threatened by the MNC palm projects cannot be adequately conveyed through an examination of 
corporate apologia and renewal alone. Further, my own understanding of how Africentric concepts play out in actual interaction among stakeholders and the MNC would benefit greatly from ethnographic observation and immersion.

Finally, a third direction for future research might involve doing a focused study about corporate renewal discourse from the perspective of those charged with communication strategies in a MNC like Herakles Farms or SPDC in the Niger Delta. While the renewal model was initially developed on the basis of cases that focused on exemplary corporate leaders, it is clear that corporate spokespeople often create and disseminate corporate crisis responses. This role is one where the political struggles, ethical quandaries, and cultural clashes between a non-African MNC and local tribes and communities might come to the fore. This might happen because such spokespeople are themselves caught in double-binds and paradoxes in the effort to craft reputationsalvaging images and respond to demands and anger from stakeholders; or because such spokespeople become caught up in the complexities of MNC operations involving not only layers of company requirements and actors but the demands of industry, regulatory, and media entities. In any case, exploring crisis renewal and responsive hybridity from such a perspective would contribute to the development of the amended crisis renewal model.

In closing, there is a growing need to examine corporate crisis rhetoric on the African continent given the growing presence of multinational corporations incentivized by the need to exploit resources, labor, and land and entangled in complex interdependencies with local, state and international actors. This condition has resulted in 
a plethora of oppositional struggles with local communities. Issues of land rights and oil ownership point to the concerns about survival in this complex mix. These antagonisms invite corporate crisis rhetoric to not only engage in post hoc analyses, but to be responsive to the logics-in-use. Not only the success and profitability of multinational projects but the wellbeing and indeed the very survival of local communities in the African continent may depend on the responsiveness of crisis rhetoric.

Acknowledging the complexities of postcolonialism and global neoliberalism, the analyses in this dissertation sought to situate crisis rhetoric within the local experiences of multinational operations in order to critically confront relations of power that confound the crisis renewal model's goals of equity, transparency, and ethicality. A critical analysis of both apologia and renewal strategies in multinational crisis communication and the responses of local stakeholders precipitated lessons learned that informed an amendment to the Discourse of Renewal. Drawing on concepts of sankofa, indigenization, and hybridization, responsive hybridity mandates more responsive local engagements that integrate ethical vigilance, self-reflexivity, and creative hybridity into corporate crisis strategies. This amendment reframes the dimensions of the renewal model and sets the determination of renewal itself as contingent on the engagements of responsive hybridity. Reframing the renewal model in this way encourages a reframing of studies of corporate crisis rhetoric as engaged scholarship. 


\section{Bibliography}

Achobang, C.F. (2013, November 29). Cameroon President Authorizes Herakles Farms to destroy forests. Retrieved from, https://www.modernghana.com/news/505760/1/cameroon-president-authorizesherakles-farms-to-de.html

Achobang, C.F. (n.d.). Re: Cameroon: Open Letter from CEO of Herakles Farms in Response to Report on Land Deals in Africa. Retrieved from, https://www.savewildlife.org/downloads/save_the_forest/Response_C._Fon_Achobang.pdf

Alagoa, E. J. (2004). The Uses of Hindsight as Foresight: Refelections on Niger Delta and Nigerian History. Onyoma Research Publications.

Ala'i, P. (2000). The Legacy of Geographical Morality and Colonialism: A Historical Assessment of the Current Crusade Against Corruption. Vanderbilt Journal of Transnational Law, 33(4), 877-932.

Alike, E. (2011, July5). Shell seeks dialogue as Bayelsa Youths protest. LexisNexis Academic.

Alike, E. (2014, November 5). Shell Executes N2 Billion Projects to Mark Nigeria's Centenary. This day. LexisNexis Academic.

Alike, E. (2015, December 16). Again, Shell Faces Dutch Court Over Niger Delta Oil Damage. LexisNexis Academic.

Amaize, E. (2011, December 10). How Three People Died,100 Injured as Community Clashes with Security Agents. Vanguard. LexisNexis Academic.

Amaize, E. (2016, July 11). 300 Shoreline Communities accuse Shell of 'divide and rule tactics'. Vanguard. LexisNexis Academic.

Amanze-Nwachuku, C. (2012, July 5). 30 Oil Wells - FG plans new peace talks with Ogonis. This Day. LexisNexis Academic.

Amnesty International. (2015, November 3). Niger Delta: Shell's manifestly false claims about oil pollution exposed, again. Retrieved from https://www.amnesty.org/en/latest/news/2015/11/shell- false-claims-about-oilpollution-exposed/

Amnesty International. (2017, November 28). Investigate Shell for Complicity in Murder, Rape and torture. Retrieved from https://www.amnesty.org/en/latest/news/2017/11/investigate-shell-for-complicityin-murder-rape-and-torture/ 
Amodu, L.O. (2013) Community relations strategies and conflict resolution in the Niger Delta: A study of three major oil companies. Retrieved from http://covenantuniversity.edu.ng/Profiles/Amodu- Lanre/community-rela tionsstra tegies-and-conflict-resolution-in- the-niger-delta-a-study-of-three-major-oilcompanies.

Andzongo, S. (November 23, 2016). Cameroon security forces arrest 100 antidiscrimination protests. Retrieved 1/4, from http://www.reuters.com/article/uscameroon-protests-idUSKBN13I29X

Aniakor, C. (2011). Global Changes in Africa and Indigenous Knowledge: Towards Its Interrogation and Contestations. In Sam M. Onuigbo (Ed.), Indigenous Knowledge and Global Changes in Africa: History, Concepts and Logic. Nsuka: University of Nigeria.

Ang, I. (2003). Together-in-Difference: Beyond Diaspora, into Hybridity. Asian Studies Association of Australia. 27(2), 141-154. DOI: 101111/1467-8403.00147.

Ansu-Kyeremeh, K. (2005). Indigenous Communication in Africa: A Conceptual Framework. In Kwasi Ansu-Kyeremeh (ed.). Indigenous Communication in Africa: Concept, Application and Prospects. Accra: Ghana University Press.AnsuKyeremeh, K. (1997). Communication, Education and Development: Exploring an African Cultural Setting. Accra: University of Ghana Press.

Ansu-Kyeremeh, K. (1997). Communication, Education and Development: exploring an African Cultural Setting. In R. A. White (2008). Ten Major Lines of Research on Grassroots, Participatory Communication in Africa. African Communication Research, 1(1), 11-45.

Appadurai, A. (2010). Disjuncture and Difference in the Global Cultural Economy. In Day Kishan Thussu (Ed.), International Communication. Routledge.

Appadurai, A. (1996). Modernity at Large: Cultural Dimensions of Globalization. Mineapolis: University of Minnesota Press. In Kraidy, M. M. (2005). Hybridity, or the Cultural Logic of Globalization. Philadelphia: Temple University Press.

Assembe-Mvondo, S., Brockhaus, M. \& Lescuyer, G. (2013) Assessment of the Effectiveness, Efficiency and Equity of Benefit-Sharing Schemes under LargeScale Agriculture: Lessons from Land Fees in Cameroon. European Journal of Development Research, 25, 641-656. Doi:10.1057/ejdr.2013.27

Asong, S. (2013, September 2). MINFOF Evaluates Projects in SW. Cameroon Tribune.Retrieved from Lexis Nexis.

Argus, C. (2013, November 27). Herakles capital gets nod for controversial plantation. E2 Edition. Retrieved from Lexis Nexis. 
Awodiya, D. (2013). Transcultural Social Change and Development: A Critical Review of Paradigm Shifts. In Chuka Onwumechili and Ikechukwu Ndolo (Eds.). ReImagining Development Communication in Africa. Lexington Books.

Babensi II Village. (n.d.). Petition. against Herakles Farms Project. Retrieved from, https://www.oaklandinstitute.org/court-rulings-against-herakles-farms-project

Baro Village. (n.d.). Petition against Herakles Farms Project. Retrieved from, https://www.oaklandinstitute.org/court-rulings-against-herakles-farms-project.

Bhabha, H. (1994). The Location of Culture. Routledge.

Batanga Village. (2009, November 9). Letter of Opposition to Herakles Farms Project. Retrieved from, https://www.oaklandinstitute.org/court-rulings-against-heraklesfarms-project

Beoko-Ngolo Village. (2012, June 21). Letter of Opposition to Herakles Farms.

BBC News. (November 23, 2016). Bamenda protests: Mass arrests in Cameroon. Retrieved 1/4/16, from http://www.reuters.com/article/us-cameroon-protestsiduskbn13i29x

BBC News. (November 9, 2010). Nigerian Militants seize workers from Oil rig. Retrieved from, http://www.bbc.com/news/world-africa-11709762

BBC News. (May 16, 2016). Nigeria Arrests ‘Avengers' Oil Militants. BBC Online news. Retrieved from, http://www.bbc.com/news/world-africa-36301835

Benoit, W.L. (1997). Image Repair Discourse and Crisis Communication. Public Relations Review. 23(2), 177-186.

Benoit, W.L. (2004). Image Repair Discourse and Crisis Communication. In D.P. Millar, \& R.L. Heath, Eds., Responding to Crisis Communication: A Rhetorical Approach to Crisis Communication. Mahwah, New Jersey: Lawrence Erlbaum Associates

Blaney, J. R. (2002). Blowout! Firestone's image restoration campaign. Public Relations Review, 28, 379- 392.

Bobo, B.F. (2005). Rich Country, Poor Country: the Multinational as Change Agent. Connecticut: Praeger Publishers.

Cai, P., Lee, P.T. \& Pang, A. (2009). Managing a Nation's Image during Crisis: A Study of the Chinese Government's Image Repair Efforts in the 'Made in China' controversy. Public Relations Review, 35(3), 213-18. 
Cannon, J. (2016, April 7). Lessons from Herakles: sorting out a road map for palm oil in Africa: Conflict between Cameroonian communities and an American agribusiness reveals problems in low palm oil expanding across the country. Retrieved from https://news.mongabay.com/2016/04/lessons-herakles-sortingroad-map-palm-oil-africa/

Cash, A. C. (2012). Corporate Social Responsibility and Petroleum Development in subSaharan Africa: The Case of Chad. Resource Policy. 37(2), 144-151.

Chinwo, E. (2013, September 25). Shell GMoU Earns Community N50 Million MultiPurpose Hall, Others. This Day. LexisNexis Academic.

Coombs, W.T. (2007a). Protecting Organization Reputations during a Crisis: The Development and Application of Situational Crisis Communication Theory. Corporate Reputation Review, 10 (3), 163-176.

Coombs, W. T. (2007b). Attribution Theory as a guide for post-crisis communication research. Public Relations Review, 33, 135-139.

Coombs, W. T. \& Holladay, S. J. (2002). Helping Managers Protect Reputational Assets: Initial Tests of the Situational Crisis Communication Theory. Management Communication Quarterly, 16, 165- 188.

Coombs, W.T. (2004). Reasoned Action in Crisis Communication: An Attribution Theory-Based Approach to Crisis Management. Responding to Crisis: AS Rhetorical Approach to Crisis Communication. In D.P. Millar \& R.L. Heath. Mahwah, New Jersey: Lawrence Erlbaum Associates.

Coombs, W. T. (1995). Choosing the Right words: The Development of Guidelines for the Selection of the "Appropriate" Crisis-Response Strategies. Management Communication Quarterly, 8 (4), 447-476. DOI: 10.1177/0893318995008004003.

Coombs, W.T. (2013). Ongoing Crisis Communication: Planning, Managing, and Responding. 2nd Edition. Sage.

Conrad, C. \& Poole, M.S. (2012). Strategic Organizational Communication: In a Global Economy, 7th ed. Chichester, West Sussex, UK: Wiley-Blackwell.

Crable, R. E. \& Vibbert, S.T. (December, 1983.). Mobil's Epideictic Advocacy: "Observations" of Prometheus-Bound. Communication Monographs, 50, 380394.

Christians, C. G. (2004). Ubuntu and Communitarianism in Media Ethics. Ecquid Novi, 25 (2), 235-256. 
Daily Independent. (2011, February 20). Shell to Sell About \$1 billion of Assets in Africa. LexisNexis Academic.

Daily Independent. (2014, November 10). Shell Emerges Best Company in Stakeholder Engagement, Human Rights. LexisNexis Academic.

Dean, D.H. (2004). Consumer Reaction to Negative Publicity: Effects of Corporate Reputation, Response, and Responsibility for a Crisis Event. Journal of Business Communication, 41, 192-211.

Deming, S. H. (2005) The Foreign Corrupt Practices Act And the New International Norms", American Bar Association, ISBN 1-59031-326-7 p.15 (cite for facilitation payment).

Ding, H. (2014). Rhetoric of a Global Epidemic: Transcultural Communication about SARS. Carbondale: Southern Illinois University Press.

Dugbe, J. (2014, November 25). Shoreline Communities give SPDC seven-day ultimatum over Oil Spillage. Daily Independent. LexisNexis Academic.

Douglas Rasmussen: What can libertarians learn from Aristotle? [video] retrieved from, https://www.youtube.com/watch?v=b9_KGLqEljQ

Ebanga Village. (2012, March 31). Letter of Opposition to Herakles Farms Project. Retrieved from, https://www.oaklandinstitute.org/court-rulings-against-heraklesfarms-project

El-Ojeili, C. \& Hayden, P. (2006). Critical Theories of Globalization. Palgrave MacMillan.

Famakinwa, J.O. (2010). The Moderate Communitarian Individual and the Primacy of Duties. Theoria. 76, 152-166. DOI: 10.1111/j.1755-2567.2010.01064.x

Faniran, J.O. (2008). Towards a Theory of African Communication. In J.O. Faniran, Foundation of African Communication. Ibadan. Spectrum Books.

Fatade, W. (May 28, 2009). Niger Delta Offensive Intensifies. Retrieved from, 234next.com.

Fabe-Bima Village. (2011, April 5). Letter of Opposition to Herakles Farms Project. Retrieved from, https://www.oaklandinstitute.org/court-rulings-against-heraklesfarms-project

Fabe-Bima Village. (2011, January 23). Letter of Opposition to Herakles Farms Project. Retrieved from, https://www.oaklandinstitute.org/court-rulings-against-heraklesfarms-project 
Fairhurst, G.T. (2007). Discursive Leadership:In Conversation with Leadership Psychology. Thousand Oaks, CA: Sage.

Fairhurst, G.T., \& Grant, D. (2010). The Social Construction of Leadership: A Sailing Guide. Management Communication Quarterly, 24 (2), 171-210.

Financial Times Lexicon (2016): Foreign Direct Investment. http://lexicon.ft.com/Term?term=foreign-direct-investment. Accessed May 24, 2016.

Fokwen, M. (2015, November 6). Activist jailed over Herakles Farms' Project. Cameroon Tribune. Retrieved from Lexis Nexis.

Fombad, C. M. (2009). Update: researching Cameroonian law. Retrieved from http://www.nyulawglobal.org/Globalex/Cameroon1.htm.

Fomundam, A.R. (2011). Corruption Under Cameroon Law. http://fakoamerica.typepad.com/files/corruption-under-cameroon-law_justicembah-acha.pdf Accessed May 18, 2016.

Førde, A. (2013). Female Entrepreneurship in a West African Context: Network, Improvisation and Dependency. Journal of International Women's Studies, 14(3), 83-95.

Frenkel, M. \& Shenhav, Y. (2006). From Binarism Back to Hybridity: A Postcolonial Reading of Management and Organization Studies. Organization Studies, 27(6), 855-876. DOI: $10.1177 / 0170840606064086$

Friedman, J. (1997). Global Crisis, the Struggle for Cultural Identity and Intellectual Porkbarelling: Cosmopolitans versus Locals, Ethnic and Nationals in an era of De-hegemonisation. In P. Werbner and T. Modood (Eds), Debating Cultural Hybridity. 70-89, Zed, London.

Fuanya, N. (2015, November 9). Limbe Paramount Chieftaincy Crisis. The Median Newspaper. Retrieved from http://themedianpaperyde.blogspot.com/2015/11/limbe-paramount-chieftaincy-crisis.html.

Fuse, K., Land, M \& Lambiase, J. (2010). Expanding the Philosophical Base for Ethical Public Relatins Practice: Cross-Cultural Case Application of Non-Western Ethical Philosophies. Western Journal of Communication, 4(74), 436-455. DOI: $10.1080 / 10570314.2010 .492823$

Kwek, D. (2003). Decolonizing and re-presenting culture's consequences: A postcolonial critique of cross-cultural studies in management. In A. Prasad (Ed.), Postcolonial theory and organizational analysis: A critical engagement (pp. 121-146). New York: Palgrave. 
Gbemudu, E. (2010, December 21). Bayelsa Lauds SPDC on GMoU Implementation. Daily Independent. LexisNexis Academic.

Global Data. (2011, December 26). SNEPCo Provides Update On Bonga Oil Leak in Nigeria. LexisNexis Academic.

Global Data. (2014, August 6). Shell First oil produced from SNEPCO-operated Bonga North West deep- water project in Nigeria. LexisNexis Academic.

Gale, T. (2007). Cameroon. World Encyclopedia of Nations. Retrieved from http://www.encyclopedia.com/places/africa/cameroon-political geography/cameroon\#ETHNIC_GROUPS

Geschiere, P. \& Nyamnjoh, F. (2000). Capitalism and Autochthony: The Seesaw of Mobility and Belonging. Public Culture. 12 (2), 423-452.

Grant et al. (2004). (Introduction) Organizational Discourse: Exploring the Field. In David Grant, Cynthia Hardy, Cliff Oswick \& Linda Putnam (Eds.), The Sage Handbook of Organizational Discourse. Sage.

Greenpeace Africa. (2016, October 4). 244 Cameroonian farmers bring SGSOC palm oil plantation to justice. Retrieved from, http://www.greenpeace.org/africa/en/PressCentre-Hub/Farmers-against-SGSOC/

Greenpeace Africa. (2016, September 6). Herakles Farms/SGSOC: The chaotic history of a destructive Palm Oil Project in Cameroon. Retrieved from, http://www.greenpeace.org/africa/en/Press-Centre-Hub/Publications/HeraklesFarmsSGSOC-The-chaotic-history-of-destructive-palm-oil-project-in-Cameroon/

Greenpeace International \& Oakland Institute. (2013). Herakles exposed: The truth behind Herakles Farms' false promises in Cameroon. Retrieved from, https://www.oaklandinstitute.org/herakles-exposed

Greenpeace International. (2013, March 5). Herakles farms in Cameroon: A showcase in bad Palm Oil Production. Retrieved from, www.greenpeace.org/usa/wpcontent/uploads/legacy/.../usa/.../HeraklesCrimeFile.pdf

Greenpeace International. (2014, May). License to Launder: How Herakles Farms' illegal timber trade threatens Cameroon's forests and VPA. Retrieved from, http://www.greenpeace.org/international/en/publications/Campaignreports/Forests-Reports/Licence-to-Launder/

Grimes, D.S. \& Parker, P.S. (2008). Imagining Organizational Communication as a Decolonizing Project. In Conversation with Broadfoot, Munshi, Mumby, and 
Stohl. Management Communication Quarterly, pp. 1-10.

Doi:10.1177/0893318908327010

Gyekye, K. (2003). Person and Community in African Thought. In P.H. Coetzee and A.P.J. Roux (eds), The African Philosophy Reader ( $2^{\text {nd }}$ Edition), 297-312. New York: Routledge.

Gyekye, K. (1997). Tradition and Modernity. New York: Oxford University Press.

Gwillim, L. (2005): Provinces of Cameroon. Retrieved from, https://en.wikipedia.org/wiki/Regions_of_Cameroon

Hall, S. (1992). The West and the Rest: Discourse and Power. In Staurt, H. \& Bram G (Eds.) Formations of Modernity, Cambridge: Polity Press/Open University.

Hall, S. (1985). Signification, Representation, Ideology: Althusser and the PostStructuralist Debates. Critical Studies in Mass Communication, 2(2), 91-114.

Hall, S. (1997). Race, Articulation and Societies Structured in Dominance. In Sociological theories: race and Colonialism. UNESCO.

Harlow, W.F., Brantley, B.C., \& Harlow, R.M. (2011). BP Initial Image Repair Strategies after the Deepwater Horizon Spill. Public Relations Review, 37, 80-83.

Harvey, D. (2006). Spaces of Global Capitalism: towards a theory of uneven Geographical Development. London, New York: Verso.

Hearit, K. M. (2006a). Introduction: A Tale of Two Crises. Crisis Management by Apology Corporate Response to Allegations of Wrongdoing. $\neg$ Mahwah, New Jersey: Lawrence Erlbaum Associates.

Hearit, K. M. (2006b). Apologia, Social Drama, and Public Ritual. Crisis Management by Apology Corporate Response to Allegations of Wrongdoing. $\neg$ Mahwah, New Jersey: Lawrence Erlbaum Associates.

Hearit, K. M. (2006c). Legality and Liability. Crisis Management by Apology Corporate Response to Allegations of Wrongdoing. $\neg$ Mahwah, New Jersey: Lawrence Erlbaum Associates.

Hearit, K. M. (2006d). Apologetic Ethics. Crisis Management by Apology Corporate Response to Allegations of Wrongdoing. $\neg$ Mahwah, New Jersey: Lawrence Erlbaum Associates.

Hearit, K. M. (2006e). Institutional Apologies. Crisis Management by Apology Corporate Response to Allegations of Wrongdoing. $\neg$ Mahwah, New Jersey: Lawrence Erlbaum Associates. 
Hearit, K. M. (2006f). Apologia and Organizations. Crisis Management by Apology Corporate Response to Allegations of Wrongdoing. $\neg$ Mahwah, New Jersey: Lawrence Erlbaum Associates.

Heath, R. L. \& Millar, D. P. (2004). A Rhetorical Approach to Crisis Communication Processes, and Strategic Responses. In D. P. Millar \& R.L. Heath (Eds.).

Responding to Crisis: A Rhetorical Approach to Crisis Communication. Mahwah, New Jersey: Lawrence Erlbaum Associates.

Held, D. (2004). Global Covenant: The Social Democratic Alternative to the Washington Consensus. Cambridge, UK: Polity Press.

Herakles Farms. (2011, 2011). Environmental and Social Impact Assessment Report. Retrieved from, https://www.oaklandinstitute.org/environmental-and-socialimpact-assessment-report-august-2011

Herakles Farms. (2012, March 20). A Response to Inquiries Regarding the Sustainability and Intentions of the Herakles Farms SG Sustainable Oils Project in Southwest Cameroon. Retrieved from https://business-humanrights.org/en/a-response-toinquiries-regarding-the-sustainability-and-intentions-of-the-herakles-farms-sgsustainable-oils-project-in-southwest-cameroon

Herakles Farms. (n.d.) Investment Opportunity. Retrieved from, https://www.oaklandinstitute.org/herakles-farms-documentation

Herakles Farms. (n.d.). Executive Summary: Investment Opportunity. Retrieved from, https://www.oaklandinstitute.org/herakles-farms-documentation

Herakles Farms. (n.d.). Investment Opportunity Presentation. Retrieved from, https://www.oaklandinstitute.org/herakles-farms-documentation

Herakles Farms. (n.d.). SGSOC Convention with the Government of Cameroon. Retrieved from, https://www.oaklandinstitute.org/sgsoc-convention-governmentcameroon

Herakles Farms. (n.d.). Value Drivers. Retrieved from, https://www.oaklandinstitute.org/herakles-farms-documentation

Hesford, W. S. \& Schell, E.E. (2008). Introduction: Configurations of Transnationality: Locating Feminist Rhetorics. Special Topic: Transnational Feminist Rhetorics, 5(70), 461-470.

Hilson, G. (2012). Corporate Social Responsibility in the Extractive Industries:

Experiences from Developing Countries. Resources Policy, 37(2), 131-137. 
Holodny, E. (May 16, 2016). Africa's Largest Oil Producer has been Dethroned. Business Insider. Retrieved from, http://uk.businessinsider.com/niger-deltaavengers-nigeria-oil-production-crash-2016-5? $\mathrm{r}=\mathrm{us} \& \mathrm{ir}=\mathrm{t}$

Huxman, S. S. (2004). Exigencies, Explanations, and Executions: Toward a Dynamic Theory of the Crisis Communication Genre. In D. P. Millar \& R.L. Heath (Eds.). Responding to Crisis: A Rhetorical Approach to Crisis Communication. Mahwah, New Jersey: Lawrence Erlbaum Associates.

IRIN Africa. (May 22, 2009). Thousands Flee Violence, Hundreds Suspected Dead. Retrieved from, http://www.irinnews.org/report/84512/nigeria-thousands-fleeviolence-hundreds-suspected-dead

Ikuenobe, P. (2006). Philosophical Perspectives on Communalism and Morality in African Traditions. Lexington Books: Rowan \& Littlefield.

Iwori, J. (2014, November 26). Host Community Opposes Sale of OML 29. LexisNexis Academic.

James, S. (2015, May 23). Youths shut down oil production in Nembe Creek. This Day. LexisNexis Academic.

Jeong, S-H. (2009). Public Responses to an oil spill accident: A test of the attribution theory and situational crisis communication theory. Public Relations Review, 35, 307-309.

Jua, N.B. (1995). Indirect Rule in Colonial and Post-Colonial Cameroon. Frobenius Institute, 39-47. Retrieved from, http://www.jstor.org/stable/40341691.

Jua, N. (2003). Differential Responses to Disappearing Transitional Pathways: Redefining Possibility among Cameroonian Youths. African Studies Review, 48 (2), 13-36.

Koos, C., Jan, P. (January 1, 2015). The Effects of Oil Production and Ethnic Representation on Violent Conflict in Nigeria: A Mixed-Methods Approach. Terrorism and Political Violence, 1-24. DOI: 10.1080/09546553.2014.962021

Knox, S., \& Maklan, S. (2004). Corporate Social Responsibility: Moving Beyond Investment Towards Measuring Outcomes. European Management Journal, 22(5), 508-516.

Kraidy, M. M. (2005). Hybridity, or the Cultural Logic of Globalization. Philadelphia: Temple University Press. 
Kuhn, T. \& Jackson, M. (2008). Accomplishing Knowledge: A Framework for Investigating Knowing in Organizations. Management Communication Quarterly, 21(4), 454-485. http://online.sagepub.com.

Lambsdorff, J.G. (2010). Who Accepts Bribery? Evidence from a Global Household Survey. Volkswirtschaftliche Reihe, ISSN 1435-3520: Universitat Passau.

Legal Monitor Worldwide. (2016, January 25). Breaching and judicialo harassment of liberty of expression in Cameroon: assurance of Nasako Besingi. Retrieved from Lexis Nexis.

LexisNexis Academic. Shell Nigeria. (2012, April). Global Memorandum of Understanding. Retrieved from, http://www.shell.com.ng/sustainability/communities/gmou.html.

Lioyd, P. C. (2007). Ethnicity and the Structure of Inequality in Warri town in the Mid1950s. In Peter Palmer Ekeh (Ed.) History of the Urhobo People of Niger Delta. Buffalo: NY. Urhobo Historical Society.

Langmia. K. (2013). Moving the Signpost in Cameroon? Resolving Inter-Village Rivalry through a Form of Communication. In Chuka Onwumechili and Ikechukwu Ndolo (Eds.). Re-Imagining Development Communication in Africa. Lexington Books.

Lanning, G. (1979). Africa Undermined: Mining Companies and the Underdevelopment of Africa. New York: Peguin Books.

Lockhart, V. (1994). A Social-Historical Study of Social Change Among the Bangwa of Cameroon. Center for African Studies: University of Edinburgh.

Low, Y.S-Y., Varughese, J. \& Pang,A. (2011). Communicating crisis: how culture influences image repair in Western and Asian governments. Corporate Communications: An International Journal, 16(3), 218-242.

Makia, I. (2013, May 23). Gov't Indicts Herakles Farms (SGSOC), Suspends Activities. Retrieved from, http://cameroonlatest.blogspot.com/2013/05/govt-indictsherakles-farms-sgsoc.html

Malle, A. (2012). Responses to Inquiries Regarding the Sustainability and Interventions of Herakles Farms SG Sustainable Oils Project in South West Cameroon-20 March, 2012. Retrieved from https://www.scribd.com/document/87055579/Response-to-Herakles-Farms-PressRelease 
Manuh, T. (2007). Doing Gender Work in Ghana. In C.M. Cole, T. Manuh, S. F. Miescher (Eds.) Africa After Gender? (125-149). Bloomington: Indiana University Press.

Mark, M. (2012, May 31). Nigeria's penalty for gas flaring will not curb emissions, say campaigners. Retrieved from https://www.theguardian.com/environment/2012/may/31/nigeria-penalty-gasflaring

Massaka Bima village. (2010, June 19). Letter of Opposition to Herakles Farms Project. Retrieved from, https://www.oaklandinstitute.org/court-rulings-against-heraklesfarms-project.

Massaka Bima Village. (2012, April 13). Youth Letter of Opposition to Herakles Farms Project. Retrieved from, https://www.oaklandinstitute.org/court-rulings-againstherakles-farms-project

Massey, J. E. (2004). Managing Organizational Images: Crisis Response and Legitimacy Restoration. In Dan P. Millar, \& Robert L. Heath (Eds.). Responding to Crisis Communication: A Rhetorical Approach to Crisis Communication. Mahwah, New Jersey: Lawrence Erlbaum Associates.

Mitroff, I.I., Shrivastava, P. \& Udwadia, F.E. (1987). Effective Crisis Management. The Academy of Management, 1(4), 283-292. Retrieved from, http://www.jstor.or/stable/4164770.

Mitroff, I.I. (1988). Crisis Management: Cutting through the Confusion. Sloan Management Review, 2(29). Retrieved from, https://search.proquest.com/openview.

Mboka Village. (n.d.). Petition against Herakles Farms Project. Retrieved from, https://www.oaklandinstitute.org/court-rulings-against-herakles-farms-project

Mbonteh, R. (2013, February 6). Palm oil stakeholders drilled on best practices. Cameroon Tribune. Retrieved from, Lexis Nexis.

Mbufong, P. (2013). The Cameroonization of English. US-China Foreign Language. 11(6), 475-482.

Mbunwe, C. (2015, March 9). Attorney General Snubs Lawyers' Protests. Cameroon Postline. Retrieved from http://www.cameroonpostline.com/attorney-generalsnubs-lawyers-protests/

McGreal, C. (1993, August 11). Spilt oil brews up a political storm; Chris McGreal reports from the Niger Delta on the Ogoni people response to Shell's pollution record. The Guardian. LexisNexis Academic. 
Millar, D. P. (2004). Exposing the Errors: An Examination of the Nature of Organizational Crisis. In D. P. Millar \& R.L. Heath (Eds.). Responding to Crisis: A Rhetorical Approach to Crisis Communication. Mahwa, New Jersey: Lawrence Erlbaum Associates.

Ministry of Forestry and Wildlife. (2012, April 26). Letter to SG Sustainable Oils Cameroon: Unauthorized felling of Trees.

https://www.oaklandinstitute.org/herakles-farms-documentation

Ministry of Forestry and Wildlife. (2012, April). Minsitry of Forestry's Report on SGSOC. Retrieved from, https://www.oaklandinstitute.org/ministry-forestrysreport-sgsoc-april-2012

Ministry of Forestry and Wildlife. (2012, February 1). Letter to SG Sustainable Oils Cameroon: Intention to clear land in the Nguti Sub-Division. Retrieved from https://www.oaklandinstitute.org/herakles-farms-documentation

Ministry of Forestry and Wildlife. (2012, May 12). Letter to SG Sustainable Oils Cameroon: Unauthorized felling of Trees. https://www.oaklandinstitute.org/herakles-farms-documentation

Ministry of Forestry and Wildlife. (2012, May 12). Letter to SG Sustainable Oils Cameroon: Unauthorized felling of Trees. Retrieved from, https://www.oaklandinstitute.org/herakles-farms-documentation

Moas, A. \& Ini, E. (2015, November 18). Herakles Farms project rears its ugly head again. Retrieved from, http://www.greenpeace.org/international/en/news/Blogs/makingwaves/heraklesfarms-palm-oil-cameroon/blog/54802/

Mogekwu, M. (2013). Going back to Basics: Shifting Research Focus to Indigenous Knowledge Systems and their Role in Development. In Chuka Onwumechili and Ikechukwu Ndolo (Eds.). Re-Imagining Development Communication in Africa. Lexington Books.

Morrison, J. (2005). Forum Theatre: A Cultural forum of Communication. In Kwasi Ansu-Kyeremeh (ed.). Indigenous Communication in Africa: Concept, Application and Prospects. Accra: Ghana University Press.

Mudimbe, V.Y. (1988). The Invention of Africa: gnosis, philosophy, and the Order of Knowledge. Indiana University Press.

Mumby, D. K. (2013). Organizational Communication: A Critical Approach. Sage Publications. 
Mumby, D. \& Stohl, C. (1991). Power and Discourse in Organization Studies: absence and dialectic of Control. Discourse \& Society, 2(3), 313-332. DOI: $10.1177 / 0957926591002003004$.

Mundemba Council. (2010, February 15). Letter of Opposition to Herakles Farms Project. Retrieved from, https://www.oaklandinstitute.org/court-rulings-againstherakles-farms-project

Munteh, Y. N. (2012, February 22). Commercial Agriculture: Poorly negotiated land leases condemned. Cameroon Tribune. Retrieved from Lexis Nexis.

Musoro, D. N. (2015, June 1). The `Frenchification` Of Anglophone Courts in Cameroon. Retrieved from https://www.linkedin.com/pulse/frenchification-anglophonecourts-cameroon-darlene-nalih-musoro

Mvogo, B. [Blaise]. (2016a, January, 18). SGSOC Activities Assessed. [Facebook status update, Video file]. Retrieved from https://www.facebook.com/blaise.mvogo/videos/1198624420167744/?permPage= 1

Mvogo, B. [Blaise]. (2016b, January, 20). SGSOC: Environmental concerns given due attention [Facebook status update, Video file]. Retrieved from https://www.facebook.com/blaise.mvogo/videos/vb.100000605938973/11986244 $20167744 /$ ?type $=2 \&$ theater

Mvogo, B. [Blaise]. (2016c, January, 21). SGSOC: the out grower scheme. [Facebook status update, Video file]. Retrieved from https://www.facebook.com/blaise.mvogo/videos/vb.100000605938973/11991992 $03443599 /$ ?type $=2 \&$ theater

Mvogo, B. [Blaise]. (2016d, January, 21). SGSOC: 21 Billion spent no return on investment [Facebook status update, Video file]. Retrieved from Mvogo, B. [Blaise]. (2016d, January, 20). Retrieved from https://www.facebook.com/blaise.mvogo/videos/1199160466780806/

Nederveen, J, P. (2015). Globalization and Culture: Global Melange (3rd ed.). Rowan \& Littlefield.

Nguifo, S. (2013, October). Dispossessed at all costs? Remarks on the process of allocating land to SGSOC in Nguti sub-division. Retrieved from, www.relufa.org/documents/201310_Dispossessedatallcosts.pdf

Nguti Sub-Divisional Chiefs. (2010, June 12). Letter of Opposition to Herakles Farms Project. Retrieved from, https://www.oaklandinstitute.org/court-rulings-againstherakles-farms-project 
Niger Delta Development Commission (NDDC). (2005). The Niger Delta Region: Land and People. Niger Delta Regional Development Master Plan. Retrieved from http://www.nddc.gov.ng/masterplan.html

Nsamenang, A.B. (2013). The Indigenous and the Alien in Cameroon Writing. In H. N. Eyoh, A. Azeyeh, \& N. Lyonga (Eds), 37-54. African Books Collective.

Nyuylime, L.P. (2012, May 14). Oil palm production: Conservatists call for sustainability. Cameroon Tribune. Retrieved from, Lexis Nexis.

Nzeshi, O. (2013, February 6). House Tasks UNEP On Oil Pollution in Ogoniland. This Day. LexisNexis Academic.

Nwachuku, C. (2015, May 6). Social Investment, Key to Sustainable Development Shell. Vanguard. LexisNexis Academic.

Oakland Institute. (2011, 2012). Court Rulings against Herakles Farms Project. Retrieved from, https://www.oaklandinstitute.org/court-rulings-against-herakles-farmsproject

Oakland Institute. (2012, June). Europe Aid Independent Observer Official Report regarding SG Sustainable Oils Cameroon. Retrieved from, https://www.oaklandinstitute.org/herakles-farms-documentation

Oakland Institute. (2012, September). Understanding Land Investment Deals in Africa: Massive Deforestation portrayed as Sustainable Development: The Deceit of Herakles Farms in Cameroon. Retrieved from, https://www.oaklandinstitute.org/sites/oaklandinstitute.../Land_deal_brief_herakle s.pdf

Oakland Institute. (2016, August 29). Backroom Bulling: The Role of the US Government in the Herakles Farms' Land Grab in Cameroon. Retrieved from, https://www.oaklandinstitute.org/us-bullies-cameroon-herakles

Oakland Institute. (n.d.). Letter from Eleven Scientists on the Project. Retrieved from, https://www.oaklandinstitute.org/letter-11-scientists-project

Oakland Institute. (n.d.). Letters of Opposition to Herakles Farms project. Retrieved from against Herakles Farms Project. Retrieved from, https://www.oaklandinstitute.org/court-rulings-against-herakles-farms-project

Oduma, I. (2011, June 22). SPDC Splashes N103 Million On Self-Reliance Programme. Daily Independent. LexisNexis Academic.

Okie, E.B. (December 13, 2016). Cameroon urged to investigate deaths amid Anglophone protests. The Guardian, Retrieved, 1/4, from 
https://www.theguardian.com/world/2016/dec/13/cameroon-urged-investigateclashes-anglophone-regions.

Onah, G. (2010, November 4). Shell Awards Scholarships to 50 Rivers Students. LexisNexis Academic.

Ogbu, A. (2012, March 2). Jonathan Charges Shell On Oil Spills. This Day. LexsisNexis Academic.

Onukwugha, A. (2011, August 23). Shell to Sustain GMOU with Niger Delta Communities. Leadership. LexisNexis Academic.

Opio, A. (2012, May 14). How a U.S. Company is breaking Laws and Grabbing Land in Africa. Retrieved from http://www.alternet.org/story/155358/how_a_u.s._company_is_breaking_laws_an d_grabbing_land_in_africa

Orogun, P.S. (2010). Resource Control, Revenue Allocation and Petroleum Politics in Nigeria: the Niger Delta Question. GeoJournal, 75(5), 459-507.Retrieved from http://www.jstor.org/stable/41148413

Oyadongha, S. (2011, March 3). Bayelsa Communities, SPDC implement GMoU, award 130 Students Scholarship. Vangaurd. LexisNexis Academic.

Oyeshile, O. A. (2004). Communal Values, Cultural Identity and the Challenges of Development in Contemporary Africa. The Journal of Social, Political, and Economic Studies, 29(3), 291-303.

Oyowe, O. A. (2013). Personhood and Social Power in African Thought. Alternation, 20 (1), 203- 228

Penderis, S. (2012). Theorizing Participation: from Tyranny to Emancipation. Journal of African \& Asian Local Governmet Studies, 1(3).

Pearson, C., Dufort, R.C. \& Clair, J.A. (2007). International Handbook of Organizational Crisis Management. Sage Publications.

Putnam, L.L., \& Dempsey, S.E. (2015). The Five Faces of Engaged Scholarship: Implications for Feminist Research. Women and Langugae. 38(1), 1-177.

Program for the Sustainable Management of Natural Resources. (2013, March 1). Factfinding Mission Report. Retrieved from, https://www.oaklandinstitute.org/herakles-farms-documentation. 
Rainforest Foundation. (2016, September). Nguti Council, South-West Region, Republic of Cameroon: Forest Communities and their Traditional way of Life. Retrieved from, http://www.rainforestfoundationuk.org/community-mapping

Reierson, J.L., Sellnow, T.L. \& Ulmer, R.R. (2009). Complexities of Crisis Renewal Over Time: Learning from the Tainted Odwalla Apple Juice Case, Communication Studies, 60 (2), 114-129, DOI: 10.1080/10510970902834841

Reierson, J. \& Littlefield, R. S. (2012). History, Healing, and Hope: Reconceptualizing Crisis Renewal Theory by Developing a Model for Marginalized Communities. Review of European Studies, 4 (4), 29-44, E-ISSN1918-7181.

Reuters. (2013, May 22). U.S. Herakles farms halts Cameroon palm oil development. Retrieved from, http://www.reuters.com/article/cameroon-palmidUSL6N0E344Q20130522

Rothenberg, D. (2012, June 12). Herakles Farms Announces Update on its Cameroon Palm Oil Subsidiary SGSOC. PRNewswire. Retrieved from http://www.prnewswire.com/news-releases/herakles-farms-announces-update-onits-cameroon-palm-oil-subsidiary-sgsoc-158594925.html

SEFE. (2015, April 22). SEFE, Herakles abandons all operations in mundemba and toko concessions area. Retrieved from http://www.greenpeace.org/international/Global/international/publications/forests/ 2014/Licence-to-Launder.pdf

Seeger, M.W. \& Ulmer, R.R. (2001). Virtuous Responses to Organizational Crisis: Aaron Feuerstein and Milt Cole. Journal of Buisness Ethics, 31, 369-376.

Seeger, M.W. \& Ulmer, R.R. (2002). A Post-Crisis Discourse of Renewal: The Cases of Malden Mills and Cole Hardwoods. Journal of Applied Communication Research, 30 (2), 126-142.

Seeger, M.W, Ulmer, R.R., Novak, J. M., \& Senow T.L. (2005). Journal of Organizational Change Management, 18 (1), 78-95, PROQUEST.

Seeger, M. W. (2006). Best Practices in Crisis Communication: An Expert Panel Process. Journal of Applied Communication Research, 34(3), 232-244.

Sellnow, T. L. \& Seeger, M. W. (2013). Theorizing Crisis Communication. WileyBlackwell.

Sellnow, T. L. \& Veil, S.R. (2016). Preparing for International and Cross-Cultural Crises: The Role of Competing Voices, Inclusivity, and the Interplay of Responsibility in Global Organizations. In Schwarz A., Seeger M.W., \& Auer C. (Eds.), The 
Handbook of International Crisis Communication Research (pp.489-498). Willy Blackwell.

Senior, Y. (2011, July 14). Shell Seeks Dialogue as host Communities besiege its Bayelsa facility. Retrieved from LexisNexis Academic.

Simola, S. (2003). Ethics of justice and Care in Corporate Crisis Management. Journal of Business Ethics. 46(4), 351-361.

Simon, L., \& Pauchant, T. (2000). Developing the Three Levels of Learning in Crisis Management: A Case Study of the Hagersville Tire Fire. Review of Business, 21(3), 6-11.

Sisco, H.F., Collins, E.L. \& Zoch, L.M. (2010). Through the looking glass: A decade of Red Cross Crisis response and situational crisis communication theory. Public Relations Review, 36, 21-27. DOI: 10.1016/j.pubrev.2009.08.018.

Spivak, G.C. (1988). Can the Subaltern Speak? Retrieved from, http://www.bahaistudies.net/neurelitism/library/subaltern_speak.pdf.

Steele, J. (1995, November 11). Bloody deeds raised against a people's struggle to control their resources, suppression of protest at the rape of the Niger Delta has been sordid and violent. The Guardian. LexisNexis Academic.

Svensson, P. (2009). Embracing Left and Right: Image Repair and Crisis Communication in a Polarized Ideological Milieu. Management Communication Quarterly. 22(4), $555-576$.

Theus, K. T. (2004). Issue Management during sudden Executive Departures: Sensemaking, Enactment and Communication. In D. P. Millar \& R.L. Heath (Eds.). Responding to Crisis: A Rhetorical Approach to Crisis Communication. Mahwah, New Jersey: Lawrence Erlbaum Associates.

The Economist. (June 25, 2016). The Niger Delta Avengers: Danegeld in the Delta. Retrieved from, http://uk.businessinsider.com/niger-delta-avengers-nigeria-oilproduction-crash-2016-5?r=us\&ir=t

Tomlinson, J. (2007). Globalization and Cultural Analysis. In David, H. \& Anthony, M. (Eds.). Cambridge: Polity Press.

Udoekanem, N. B., Adoga, D. O., \& Onwumere, V. O. (2014). Land Ownership in Nigeria: Historical Development, Current Issues and Future Expectations. Journal of Environment and Earth Science, 4 (21), 182-188.

Uguru, H. \& Faul, M. (May 11, 2016). Shell Nigeria Shuts Oil Terminal as Attacks Cut Production. Settle Times. Retrieved from, 
http://www.irinnews.org/report/84512/nigeria-thousands-flee-violence-hundredssuspected-dead

Ulmer, R. R. \& Sellnow, T. L. (2000). Consistent Questions of Ambiguity in Organizational Crisis Communication: Jack in the Box as a Case Study. Journal of Business Ethics, 25, 143-155.

Ulmer, R.R. (2001). Effective Crisis through stakeholder Relationships: Malden Mills as a case Study. Management Communication Quarterly, 14(4), pp. 590-615. DOI: 10.1177/08933189011144003.

Ulmer, R.R. \& Sellnow, T.L. (2002). Crisis Management and the Discourse of Renewal: Understanding the potential for positive outcomes of crisis, Public Relations Review, 28, 361-365.

Ulmer, R. R., Sellnow, T. L., \& Seeger, M. W. (2007). Effective Crisis Communication: Moving from Crisis to Opportunity. Thousand Oaks, California: SAGE Publications.

Ulmer, R.R., Seeger, M.W. \& Sellnow, T.L. (2007). Post-Crisis Communication and Renewal: Expanding the Parameters of Post-crisis discourse. Public Relations review, 33, 130-134, doi:101016/j.pubrev.2006.11.015.

Ulmer, R.R. (2012). Increasing the Impact of Thought Leadership in Crisis Communication. Management Communication Quarterly, 26940, 523-542. DOI: 10.1177/0893318912461907.

Usuanlele. U. (2007). Urhobos in Benin 1897-1945: Changing Patterns of Relations under Colonial Rule. In Peter Palmer Ekeh (Ed.) History of the Urhobo People of Niger Delta. Buffalo: NY. Urhobo Historical Society.

U.S. Embassy Cables. (2013, February 25). Retrieved from, https://www.oaklandinstitute.org/herakles-cables

U.S. Embassy Cables. (2013, January 15). Retrieved from, https://www.oaklandinstitute.org/herakles-cables

U.S. Embassy Cables. (2013, June 25). Retrieved from, https://www.oaklandinstitute.org/herakles-cables

U.S. Embassy Cables. (2013, May 17). Retrieved from, https://www.oaklandinstitute.org/herakles-cables

U.S. Embassy Cables. (2013, May 21). Retrieved from, https://www.oaklandinstitute.org/herakles-cables 
U.S. Embassy Cables. (2013, May 24). Retrieved from, https://www.oaklandinstitute.org/herakles-cables

U.S. Embassy Cables. (2013, May 31). Retrieved from, https://www.oaklandinstitute.org/herakles-cables

U.S. Embassy Cables. (2014, March 24). Retrieved from, https://www.oaklandinstitute.org/herakles-cables

USAID. (n.d.). Property Rights and Resource Governance Country Profile: Cameroon. Retrieved from, https://www.land-links.org/country-profile/cameroon/also see http://landwise.resourceequity.org/record/1294

United Councils and Cities of Cameroon. (2016, May 18). Communal Development Plan Toko Council. Retrieved from http://www.cdrcvuc.cm/index.php/fr/document/cat_view/137-plans-communaux-dedeveloppement/138-sud-ouest/200-ndian

United Councils and Cities of Cameroon. (2016, May 18). Mundemba Communal Development Plan. Retrieved from http://www.cdrcvuc.cm/index.php/fr/document/cat_view/137-plans-communaux-dedeveloppement/138-sud-ouest/200-ndian

Uwugiaren, I. (2016, July 11). Bonga Oil Spill, Niger Delta Communities raise the alarm over Shell's crude tactics. This Day. LexisNexis Academic.

Vanguard. (2010, May 13). Shell Undertakes Electricity Projects in 133 Communities. LexisNexis Academic.

Vanguard. (2011, February 8). We've not violated GMoU on EA Oil Field - Shell. LexisNexis Academic.

Viba, J. (2013, May 22). Herakles Farms suspends activities in Cameroon. Retrieved from, http://www.businessincameroon.com/agribusiness/2205-4079-heraklesfarms-suspends-activities-in-cameroon

Walters, J. (2006, July 1). Keeping Good Companies. Retrieved from, http://encyclopedia.thefreedictionary.com/Facilitation+payment

Walker, A. (May 27 2009). Will Nigeria Oil Offensive backfire. BBC News. Retrieved from, http://news.bbc.co.uk/2/hi/africa/8068174.stm

Wambo, E. (2016, September 20). Bangolan under siege as death toll rises. Retrieved from

https://www.facebook.com/thesunnewspapercameroon/photos/a.26990493669109 
7.1073741827.269890016692589/330305627317694/?type=3\&_omment id $=332$ $418350439755 \&$ comment_tracking=\%7B\%22tn\%22\%3A\%22R\%22\%7D

Ware, B.L. \& Linkugel, W. A. (1973). They Spoke in Defense of Themselves: on the Generic Criticism of Apologia, 273-283. Retrieved from, http://www.uky.edu/ addesa01/documents/Ware.pdf.

Werbner, P. \& Modood, T. (1997). Debating Cultural Hybridity. London: Zed Books.

White, R. A. (2008). Ten Major Lines of Research on Grassroots, Participatory Communication in Africa. African Communication Research, 1(1), 11-4.

Wily, L. A. (2013). Enclosure revisited: putting the global land rush in historical perspective. In Handbook of Land Water Grabs in Africa, Tony Allan, Martin Keulertz, Suvi Sojamo and Jeroen Warner (eds). Londondon and New York: Routledge.

Winslow, R. (n.d.). A Comparative Criminology Tour of the World. Retrieved from http://www-rohan.sdsu.edu/faculty/rwinslow/africa/cameroon.html

World Bank. (2016). Foreign Direct Investment, Net Inflows. Retrieved from, http://data.worldbank.org/indicator/bx.klt.dinv.cd.wd.

Wrobel, B. (2012, September 17). Open Letter of Bruce Wrobel, CEO of Herakles Farms in Response to the Report Issued September 2012 by the Oakland Institute titled "Understanding Land Investment Deals in Africa" with the sub - heading “...The Deceit of Herakles Farms in Cameroon." Retrieved from, https://www.modernghana.com/news/418212/1/oakland-report-re-herakles-farmsin-cameroon.html

Yafugborhi, E. (2012, July 24). Koroama Women Protest alleged neglect by Shell. Vanguard. LexisNexis Academic.

Yin, R. K. (2009). Case Study Research: Design and Methods (4 ed.). Sage.

Zoller, H. \& Fairhurst, G. (2007). Resistance Leadership: The overlooked potential in critical organization and leadership studies. Human Relations, 60(9), 1331-1360. 